\title{
Dietary Patterns before and during Pregnancy and Risk of Hypertensive Disorders of Pregnancy: A Systematic Review
}

The Pregnancy and Birth to 24 Months Project

Published date: April 15, 2019

Nutrition Evidence Systematic Review

Center for Nutrition Policy and Promotion

Food and Nutrition Service

U.S. Department of Agriculture

3101 Park Center Drive

Alexandria, Virginia 
This systematic review was conducted for the Pregnancy and Birth to 24 Months Project (P/B-24 Project) by the Nutrition Evidence Systematic Review (NESR) team at the Center for Nutrition Policy and Promotion, Food and Nutrition Service, USDA. All systematic reviews from the P/B-24 Project are available on the NESR website: https://nesr.usda.gov.

Conclusion statements drawn as part of this systematic review describe the state of science related to the specific question examined. Conclusion statements do not draw implications, and should not be interpreted as dietary guidance.

The contents of this document may be used and reprinted without permission. Endorsements by NESR, the Center for Nutrition Policy and Promotion, the Food and Nutrition Service, or the U.S. Department of Agriculture (USDA) of derivative products developed from this work may not be stated or implied.

In accordance with Federal civil rights law and USDA civil rights regulations and policies, the USDA, its Agencies, offices, and employees, and institutions participating in or administering USDA programs are prohibited from discriminating based on race, color, national origin, religion, sex, gender identity (including gender expression), sexual orientation, disability, age, marital status, family/parental status, income derived from a public assistance program, political beliefs, or reprisal or retaliation for prior civil rights activity, in any program or activity conducted or funded by USDA (not all bases apply to all programs). Remedies and complaint filing deadlines vary by program or incident.

Persons with disabilities who require alternative means of communication for program information (e.g., Braille, large print, audiotape, American Sign Language, etc.) should contact the responsible Agency or USDA's TARGET Center at (202) 720-2600 (voice and TTY) or contact USDA through the Federal Relay Service at (800) 877-8339. Additionally, program information may be made available in languages other than English.

To file a program discrimination complaint, complete the USDA Program Discrimination Complaint Form, AD3027, found online at How to File a Program Discrimination Complaint and at any USDA office or write a letter addressed to USDA and provide in the letter all of the information requested in the form. To request a copy of the complaint form, call (866) 632-9992. Submit your completed form or letter to USDA by: (1) mail: U.S. Department of Agriculture, Office of the Assistant Secretary for Civil Rights, 1400 Independence Avenue, SW, Washington, D.C. 20250-9410; (2) fax: (202) 690-7442; or (3) email: program.intake@usda.gov.

USDA is an equal opportunity provider, employer, and lender.

\section{Suggested citation for this systematic review:}

Nutrition Evidence Systematic Review Team and Pregnancy Technical Expert Collaborative. Dietary Patterns before and during Pregnancy and Risk of Hypertensive Disorders of Pregnancy: A Systematic Review. Pregnancy and Birth to 24 Months Project. Alexandria, VA: U.S. Department of Agriculture, Food and Nutrition Service, Center for Nutrition Policy and Promotion, April 2019. Available at: https://nesr.usda.gov/project-specific-overview-pb-24-0

This systematic review has also been published in the American Journal of Clinical Nutrition: Raghavan R, Dreibelbis C, Kingshipp BL, Wong YP, Abrams B, Gernand AD, et al. Dietary patterns before and during pregnancy and maternal outcomes: a systematic review. Am J Clin Nutr. 2019;109(7):705S-28S. doi: 10.1093/ajcn/nqy216

Related citations are published in the American Journal of Clinical Nutrition:

- P/B-24 Project overview: Stoody EE, Spahn JM, Casavale KO. The Pregnancy and Birth to 24 Months Project: a series of systematic reviews on diet and health. Am J Clin Nutr. 2019;109(7):685S-97S. doi: 10.1093/ajcn/nqy372.

- P/B-24 systematic review methodology: Obbagy JE, Spahn JM, Wong YP, Psota TL, Spill MK, Dreibelbis C, et al. Systematic review methodology used in the Pregnancy and Birth to 24 Months Project. Am J Clin Nutr. 2019;109(7):698S-704S. doi: 10.1093/ajcn/nqy226

- Related systematic reviews from the P/B-24 Project: Raghavan R, Dreibelbis C, Kingshipp BL, 
Wong YP, Abrams B, Gernand AD, et al. Dietary patterns before and during pregnancy and birth outcomes: a systematic review. Am J Clin Nutr. 2019;109(7):729S-56S. doi: 10.1093/ajcn/nqy353. 


\section{ACKNOWLEDGEMENTS}

Pregnancy Technical Expert Collaborative (TEC) members:

- Barbara Abrams, DrPH, RD, University of California, Berkeley School of Public Health

- Anne Bartholomew, MS, RD, USDA

- Lisa M. Bodnar, PhD, MPH, RD, University of Pittsburgh School of Public Health

- Alison Gernand, PhD, MPH, RD The Pennsylvania State University

- Kathleen Rasmussen, ScD, RD, Cornell University

- Anna Maria Siega-Riz, PhD, University of Virginia School of Nursing

- Jamie S. Stang, PhD, MPH, RDN, University of Minnesota School of Public Health

\section{Nutrition Evidence Systematic Review (NESR) team:}

- Ramkripa Raghavani, DrPH, MPH, MSc, Panum Group, Lead analyst

- Carol Dreibelbisi, MPH, Panum Group, Analyst

- Brittany L. Kingshippi, PhD, Panum Group, Analyst (01/2017-Present)

- Yat Ping Wong, MLS, MPH, USDA, Librarian

\section{Project Leads:}

- Eve Essery Stoody, PhD, USDA

- Joanne M. Spahn, MS, RDN, USDA

- Kellie O. Casavale, PhD, RD, HHS

Federal Expert Group (FEG)-Technical Expert Collaborative (TEC) Liaisons:

- Anne Bartholomew, MS, RD, USDA

All TEC and NESR team members, Project leads, and FEG-TEC liaisons participated in establishing the research questions, analytic framework, and study inclusion and exclusion criteria. RR, CD, and YPW developed and conducted the literature search. $R R, C D$, and $B L K$ screened search results, identified studies for inclusion, extracted data, and assessed risk of bias for included studies. BA, AB, LMB, AG, KR, AMSR, JSS, EES, JMS, and KOC reviewed and provided substantive feedback on all systematic review materials, including the synthesis of the body of evidence, conclusion statement, and grade of the strength of the evidence. RR prepared this report and EES, JMS, and KOC provided oversight. All authors critically reviewed and approved the final report. The authors declare no conflicts of interest.

FUNDING SOURCE: United States Department of Agriculture, Food and Nutrition Service, Center for Nutrition Policy and Promotion, Alexandria, VA

i Under contract with the Food and Nutrition Service, United States Department of Agriculture. 


\section{TABLE OF CONTENTS}

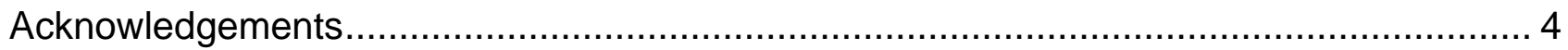

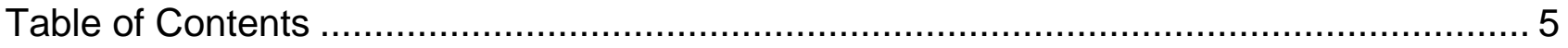

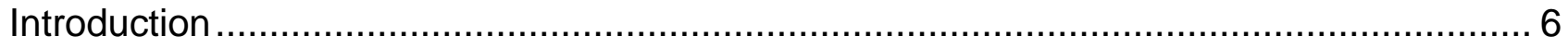

What is the relationship between dietary patterns before and during pregnancy and risk of hypertensive disorders of pregnancy? ................................................................. 2

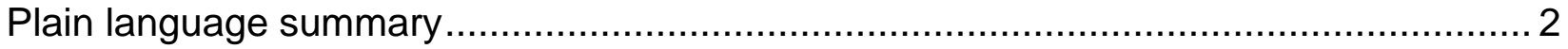

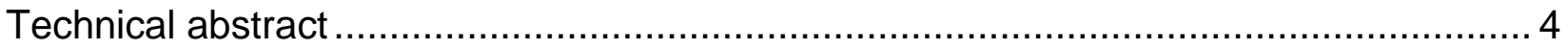

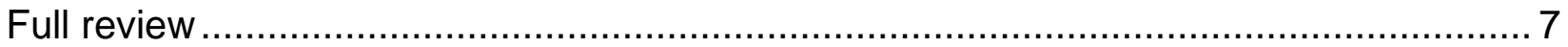

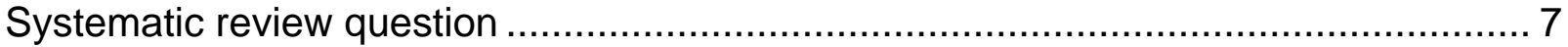

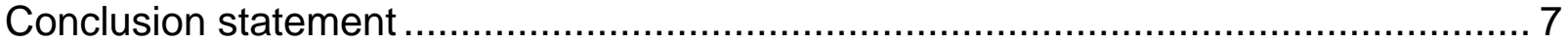

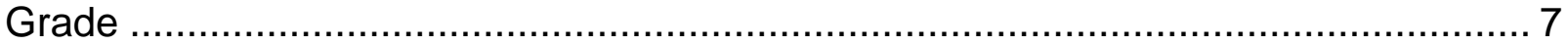

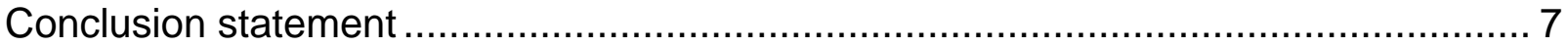

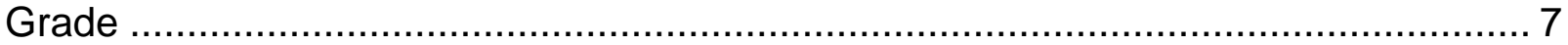

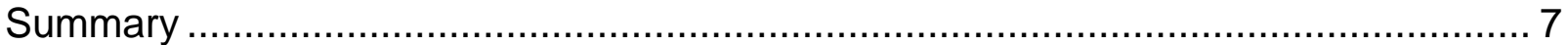

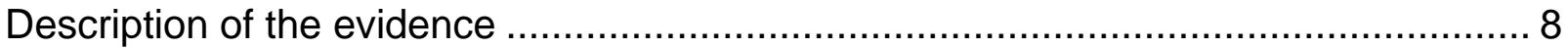

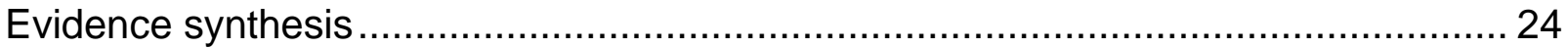

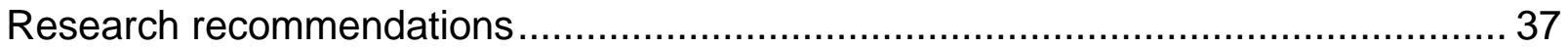

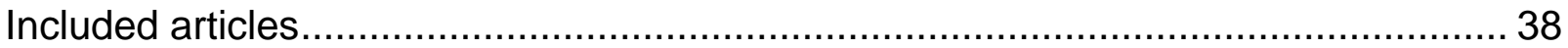

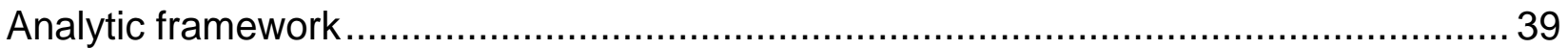

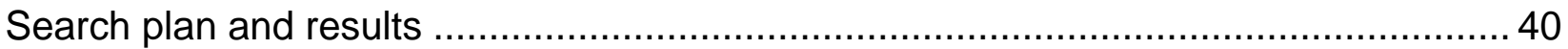

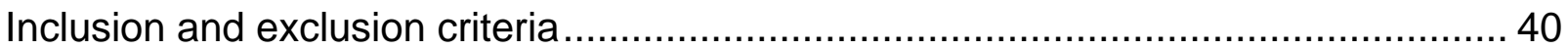

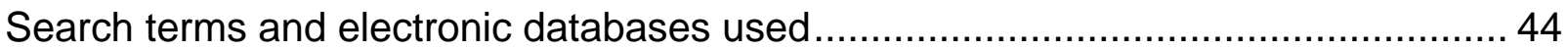

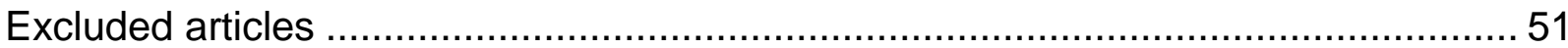

Table 1: Indices and scores used to assess the relationship between dietary patterns before and during pregnancy and risk of HDP .................................................... 10

Table 2: Summary of dietary patterns identified using factor or principal component

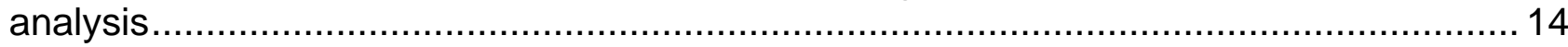

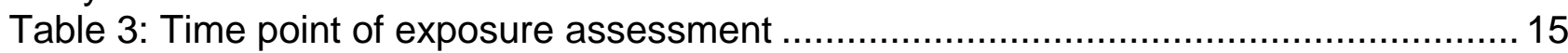

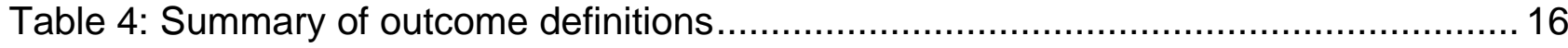

Table 5: Results grouped by methodology used for dietary pattern assessment............... 26

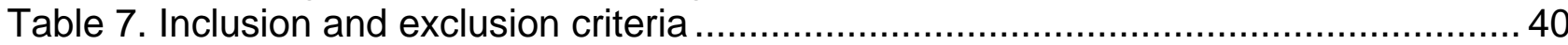

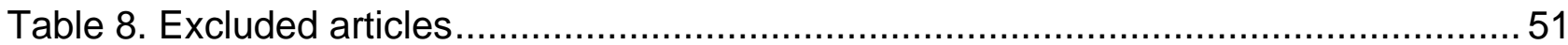

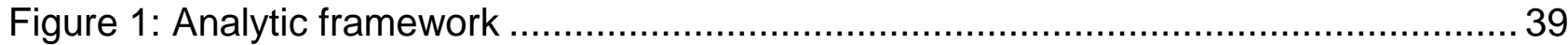

Figure 2: Flow chart of literature search and screening results...................................50 


\section{INTRODUCTION}

This document describes a systematic review conducted to answer the following question: What is the relationship between dietary patterns before and during pregnancy and risk of hypertensive disorders of pregnancy? This systematic review was conducted as part of the Pregnancy and Birth to 24 Months (P/B-24) Project by USDA's Nutrition Evidence Systematic Review (NESR).

The purpose of the P/B-24 Project was to conduct a series of systematic reviews on diet and health for women who are pregnant and for infants and toddlers from birth to 24 months of age. This project was a joint initiative led by USDA and HHS, and USDA's NESR carried out all of the systematic reviews. A Federal Expert Group (FEG), a broadly representative group of Federal researchers and program leaders, also provided input throughout the P/B-24 Project. More information about the P/B-24 Project has been publishedi and is available on the NESR website: https://nesr.usda.gov/project-specificoverview-pb-24-0.

NESR, formerly known as the Nutrition Evidence Library (NEL), specializes in conducting food- and nutrition-related systematic reviews using a rigorous, protocol-driven methodology. To conduct each P/B-24 systematic review, NESR's staff worked with a Technical Expert Collaborative (TEC), which is a group of 7-8 leading subject matter experts.

NESR's systematic review methodology involves developing and prioritizing systematic review questions, searching for and selecting studies, extracting and assessing the risk of bias of data from each included study, synthesizing the evidence, developing a conclusion statement, grading the evidence underlying the conclusion statement, and recommending future research. A detailed description of the methodology used in conducting systematic reviews for the P/B-24 Project has been publishediii and is available on the NESR website: https://nesr.usda.gov/pb-24-project-methodology-0. In addition, starting on page 39, this document includes details about the methodology as it was applied to the systematic review described herein. An analytic framework that illustrates the overall scope of the question, including the population, the interventions and/or exposures, comparators, and outcomes of interest, is found on page 39. In addition, the literature search plan that was used to identify studies included in this systematic review is found on page 40.

\footnotetext{
ii Stoody EE, Spahn JM, Casavale KO. The Pregnancy and Birth to 24 Months Project: a series of systematic reviews on diet and health. Am J Clin Nutr. 2019;109(7):685S-97S. doi: 10.1093/ajen/nqy372.

iii Obbagy JE, Spahn JM, Wong YP, Psota TL, Spill MK, Dreibelbis C, et al. Systematic review methodology used in the Pregnancy and Birth to 24 Months Project. Am J Clin Nutr. 2019;109(7):698S704S. doi: 10.1093/ajcn/nqy226.
} 


\section{List of abbreviations}

\begin{tabular}{ll}
\hline Abbreviation & Full name \\
\hline FEG & Federal Expert Group \\
\hline HHS & Department of Health and Human Services \\
\hline NEL & Nutrition Evidence Library \\
\hline NESR & Nutrition Evidence Systematic Review \\
\hline P/B-24 & Pregnancy and Birth to 24 Months Project \\
\hline TEC & Technical Expert Collaborative \\
\hline USDA & United States Department of Agriculture \\
\hline
\end{tabular}




\section{PLAIN LANGUAGE SUMMARY}

What is the question?

- The question is: What is the relationship between dietary patterns before and during pregnancy and risk of hypertensive disorders of pregnancy?

\section{What is the answer to the question?}

- Limited evidence in healthy Caucasian women with access to health care suggests that dietary patterns before and during pregnancy higher in vegetables, fruits, whole grains, nuts, legumes, fish, and vegetable oils and lower in meat and refined grains are associated with a reduced risk of hypertensive disorders of pregnancy, including preeclampsia and gestational hypertension. Not all components of the assessed dietary patterns were associated with all hypertensive disorders.

- Evidence is insufficient to estimate the association between dietary patterns before and during pregnancy and risk of hypertensive disorders of pregnancy in minority women and those of lower socioeconomic status.

Why was this question asked?

- This important public health question was identified and prioritized as part of the U.S. Department of Agriculture and Department of Health and Human Services Pregnancy and Birth to 24 Months Project.

\section{How was this question answered?}

- A team of Nutrition Evidence Systematic Review staff conducted a systematic review in collaboration with a group of experts called a Technical Expert Collaborative.

\section{What is the population of interest?}

- Women who are pregnant or able to become pregnant, ages 15-44 years.

\section{What evidence was found?}

- These studies assessed the relationship between dietary patterns before and during pregnancy and hypertensive disorders of pregnancy (including preeclampsia and gestational hypertension).

- 5 of the 8 included studies showed that the diet eaten before and during pregnancy was related to risk of hypertensive disorders of pregnancy (HDP).

- Beneficial diets had higher amounts of vegetables, fruits, whole grains, nuts, legumes, fish and vegetable oils

- Harmful diets had higher amounts of meats, potatoes and processed foods

- One other study showed an association between diet during pregnancy and blood pressure but not preeclampsia or gestational hypertension. 
- The body of evidence is limited in several ways. For example, there was little racial/ethnic and socioeconomic diversity in these studies, and it is difficult to compare studies due to inconsistency in how dietary patterns were measured.

- Additional research is needed to assess the relationship between dietary patterns before and during pregnancy and hypertensive disorders of pregnancy.

How up-to-date is this review?

- This review includes literature from $01 / 1980$ to $01 / 2017$. 


\section{TECHNICAL ABSTRACT}

\section{Background}

- Systematic reviews were conducted as part of the U.S. Department of Agriculture and Department of Health and Human Services Pregnancy and Birth to 24 Months Project.

- The goal of this systematic review was to examine the following question: What is the relationship between dietary patterns before and during pregnancy and risk of hypertensive disorders of pregnancy?

\section{Conclusion Statement and Grades}

- Limited evidence in healthy Caucasian women with access to health care suggests that dietary patterns before and during pregnancy higher in vegetables, fruits, whole grains, nuts, legumes, fish, and vegetable oils and lower in meat and refined grains are associated with a reduced risk of hypertensive disorders of pregnancy, including preeclampsia and gestational hypertension. Not all components of the assessed dietary patterns were associated with all hypertensive disorders.

\section{Grade: Limited}

- Evidence is insufficient to estimate the association between dietary patterns before and during pregnancy and risk of hypertensive disorders of pregnancy in minority women and those of lower socioeconomic status.

\section{Grade: Grade not assignable}

\section{Methods}

- The systematic review was conducted using a priori design.

- Literature searches were conducted using PubMed, Embase, Cochrane, and other databases to identify studies that evaluated the relationship between dietary patterns before and during pregnancy and risk of hypertensive disorders of pregnancy, and hand-searches were conducted.

- Studies were dual screened, and those that met the following criteria were included in the review: randomized controlled trials (RCTs), prospective or retrospective cohort studies or nested case-control studies; studies enrolling human subjects who were pregnant women or women capable of becoming pregnant, healthy or at elevated chronic disease risk (only some, not all, could have a chronic or pregnancy-related condition), and between the ages of 15 and 44; subjects from countries with high or very high human development (2015 Human Development Index); and studies published in English between January 1980 and January 2017 in peer-reviewed journals.

- The intervention or exposure was dietary patterns before and/or during pregnancy measured via indices and scores, cluster or factor analysis, reduced rank regression, or other methods. The outcome were risk of hypertensive disorders of pregnancy and related intermediate outcomes (blood pressure and proteinuria).

- Data from each included article were extracted, risk of bias was assessed, and both were checked for accuracy.

- The evidence was qualitatively synthesized, a conclusion statement was 
developed, and the strength of the evidence (grade) was assessed using preestablished criteria including evaluation of the internal validity/risk of bias, adequacy, consistency, impact, and generalizability of available evidence.

\section{Summary of Evidence}

- This systematic review includes 8 studies (sample size ranging from 290 to 72,072) within 4 cohorts and 1 RCT, published between 2005 and 2016.

- The studies used multiple approaches to assess dietary patterns, which makes it difficult to compare findings across studies. Three studies used indices/scores to assess dietary patterns, four studies used factor or principal component analysis and one RCT assigned participants to either an experimental or control diet.

- Despite this variability, 5 of the 8 included studies reported statistically significant associations between dietary patterns and hypertensive disorders of pregnancy (HDP) risk among healthy Caucasian women with access to health care. An additional study showed an association between dietary patterns and blood pressure but not preeclampsia or gestational hypertension.

- Dietary patterns characterized by higher intakes of vegetables, fruits, whole grains, nuts, legumes, fish and vegetable oils were associated with a $30-42 \%$ decreased risk of HDP and a $14-29 \%$ decreased risk of preeclampsia.

- Two of the dietary patterns assessed were reported to be detrimental: traditional and processed food patterns, characterized by higher intakes of meats, potatoes and processed foods. One was associated with a $21 \%$ increased risk of preeclampsia and the other was associated with an increased risk of high blood pressure during pregnancy.

- Generalizability of the included studies is limited to healthy Caucasian women who have access to health care. Minority women and those of lower socioeconomic status are underrepresented in this body of evidence.

- The body of evidence has several limitations:

- The evidence base includes eight studies from only four unique cohorts and one RCT

- All but one of the studies were conducted outside the United States in predominantly Caucasian women

- Dietary patterns vary considerably across studies, making it difficult to compare findings

- No adjustment was made for many key confounding factors, and

- The data are primarily observational, limiting the ability to draw any casual inferences. The RCT was done among 240 women and was not powered to examine HDP (addressed by the authors as "hypertensive complications"). Additionally, the timing of the intervention in the RCT may have been too late in pregnancy to have seen an effect.

- Additional research is needed that should:

- Include diverse populations from the U.S. and elsewhere with varying racial/ethnic and socioeconomic backgrounds

- Develop and validate novel epidemiological tools that can accurately capture the complexity of dietary habits

- Improve comparability across studies by increasing the uniformity of 1) 
diet assessment tools used across different regions and populations, 2) methods used to define dietary patterns, and 3) timing of dietary assessment

- Adjust for key confounding factors in observational studies, including parity, educational attainment, smoking status, race/ethnicity, maternal age, family poverty income ratio, pre-pregnancy BMI, mean total energy intake, and gestational diabetes mellitus (and/or justify how and why confounders were chosen)

- Include well-designed and sufficiently powered RCTs

- Include and assess effect measure modification in multiethnic subgroups within the U.S., and

- Use robust statistical methods such as multiple imputation to handle missing data. 


\section{FULL REVIEW}

\section{Systematic review question}

What is the relationship between dietary patterns before and during pregnancy and risk of hypertensive disorders of pregnancy?

\section{Conclusion statement}

Limited evidence in healthy Caucasian women with access to health care suggests that dietary patterns before and during pregnancy higher in vegetables, fruits, whole grains, nuts, legumes, fish, and vegetable oils and lower in meat and refined grains are associated with a reduced risk of hypertensive disorders of pregnancy, including preeclampsia and gestational hypertension. Not all components of the assessed dietary patterns were associated with all hypertensive disorders.

\section{Grade}

Limited: This grade is assigned to the statement relevant to healthy Caucasian women with access to health care

\section{Conclusion statement}

Evidence is insufficient to estimate the association between dietary patterns before and during pregnancy and risk of hypertensive disorders of pregnancy in minority women and those of lower socioeconomic status.

\section{Grade}

Grade not assignable: This grade is assigned to the statement relevant to minority women and those of lower socioeconomic status

\section{Summary}

- This systematic review includes 8 studies (sample size ranging from 290 to 72,072 ) within 4 cohorts and 1 randomized controlled trial (RCT), published between 2005 and 2016.

- The studies used multiple approaches to assess dietary patterns, which makes it difficult to compare findings across studies. Three studies used indices/scores to assess dietary patterns, four studies used factor or principal component analysis and one RCT assigned participants to either an experimental or control diet.

- Despite this variability, 5 of the 8 included studies found statistically significant associations between dietary patterns and hypertensive disorders of pregnancy (HDP) risk among healthy Caucasian women with access to health care. An additional study showed an association between dietary patterns and blood pressure but not preeclampsia or gestational hypertension.

- Dietary patterns characterized by higher intakes of vegetables, fruits, whole grains, nuts, legumes, fish and vegetable oils were associated with a $30-42 \%$ decreased risk of HDP and a $14-29 \%$ decreased risk of preeclampsia.

- Two of the dietary patterns assessed were reported to be detrimental: traditional and processed food patterns, characterized by higher intakes of meats, potatoes and processed foods. One was associated with a 
$21 \%$ increased risk of preeclampsia and the other was associated with an increased risk of high blood pressure during pregnancy.

- Generalizability of the included studies is limited to healthy Caucasian women who have access to health care. Minority women and those of lower SES are underrepresented in this body of evidence.

\section{Description of the evidence}

- The search included articles from very high and high Human Development Index (HDI) countries and the search timeframe spanned between January 1980 and January 2017.

- This evidence review includes 7 cohort studies and $1 \mathrm{RCT}$ that examined the relationship between dietary patterns before and during pregnancy and risk of HDP and/or blood pressure (1-8). These 8 studies were part of 4 cohorts (Project Viva, Australian Longitudinal Study on Women's Health, Generation R Study and Norwegian Mother and Child Cohort Study) and 1 RCT.

- Only one of the 8 studies was conducted in the U.S. (1). Other countries in which studies were conducted include Australia, Norway and the Netherlands (2-8). See map below.

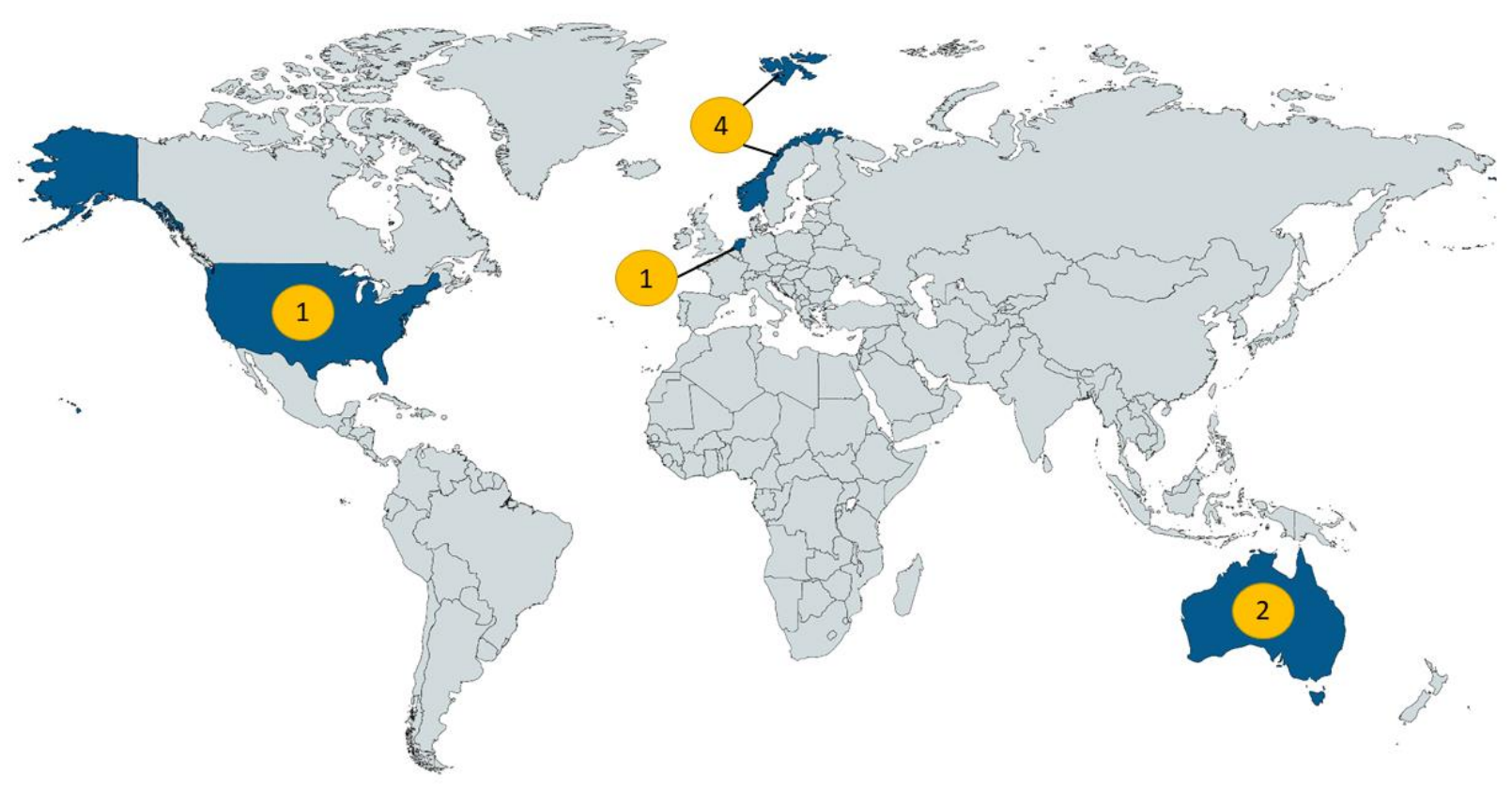

\section{Subject characteristics:}

- Sample size of the studies ranged from 290 subjects (8) to 72,072 subjects (2), with a median of 3,385 .

- Age: Most of the study participants were between 20 and 40 years, with a small percentage of women in one of the studies outside this range $(<20$ years $(4 \%)$ and $\geq 40$ years $(1 \%)(4))$.

- Pregnancy characteristics: Most of the studies $(n=6)$ included only singleton pregnancies (two did not report on pregnancy status $(3,7)$ ). 
- Health Characteristics: Overall, the studies were conducted in healthy women. Studies were variable in terms of including women with a history of chronic hypertension and HDP:

- Two studies excluded women with a history of chronic hypertension, while two additional studies excluded women with a history of chronic hypertension or $\operatorname{HDP}(3,6-8)$.

- Three studies included a small percentage of women with chronic hypertension: $1 \%(2,4,5)$.

- One study did not report on subject's chronic hypertension status prior to enrollment (1).

- Smoking during pregnancy varied across studies.

- The RCT included only non-smoking women. Previous smokers were included when they had quit smoking 5 years or more before enrolling in the study (8).

- Daily or occasional smoking among study participants: $8 \%$ (2), $9 \%$ (4), $\sim 7 \%$ (5) and $15 \%(6)$.

- Schoenaker et al. reported $\sim 20 \%$ of their participants were smokers prior to pregnancy $(7)$

- Two studies did not report smoking status $(1,3)$.

- Race/ethnicity: About half of the studies $(n=5)$ were done primarily in Caucasian populations (including the U.S. study with $72 \%$ "White" participants (1)). The rest of the studies did not report race/ethnicity $(2,3,7)$.

- Parity: Two studies recruited only nulliparous women $(4,5)$. In the other studies, the majority of the study sample was nulliparous (except (1) that included $49 \%$ nulliparous women).

- Pre-pregnancy BMI: Percentage of subjects with pre-pregnancy BMI $\geq 30$ in individual studies ranged from $\sim 7 \%$ (3) to $14 \%$ (1). Some studies reported only the mean pre-pregnancy BMI (Range: 22.3 to $24.6 \mathrm{~kg} / \mathrm{m}^{2}$ ). The RCT did not report pre-pregnancy $\mathrm{BMl}$; however, the study included only those women whose BMI was in the range of 19 to $32 \mathrm{~kg} / \mathrm{m}^{2}$ at enrollment during the second trimester of pregnancy (8).

- Maternal education: Limited information was provided on maternal education status. Mothers with at least an undergraduate degree ranged from $~ 58 \%(7)$ to $69 \%$ (1). Other studies reported that $21 \%$ (4) to $27 \%$ (5) of mothers had at least 16 years of education.

- Socioeconomic status was not reported in a majority of studies.

\section{Interventions/Exposures:}

Dietary patterns were assessed using index/score analysis and factor and principal components analysis (PCA). A description of the studies included by method used to measure dietary patterns is included below.

- Index/score analysis (Table 1: Indices and scores used to assess the relationship between dietary patterns before and during pregnancy and risk of HDP): Three studies included in this review used the following indices/scores:

- Alternate Healthy Eating Index for Pregnancy (1)

- New Nordic Diet score (2)

- Mediterranean diet score (3) 
Table 1: Indices and scores used to assess the relationship between dietary patterns before and during pregnancy and risk of HDP

\begin{tabular}{|c|c|c|c|}
\hline $\begin{array}{l}\text { Index/Score } \\
\text { (Reference) }\end{array}$ & $\begin{array}{l}\text { Alternate HEI-P } \\
\text { (min-max score) }^{1}\end{array}$ & $\begin{array}{l}\text { New Nordic Diet } \\
\text { Score }^{2,3}\end{array}$ & $\begin{array}{l}\text { Mediterranean Diet } \\
\text { Score }^{4}\end{array}$ \\
\hline Article & (1) & $(2)$ & (3) \\
\hline Component & Total Score: 0-90 & Total score: 0-10 & Total score: 0-10 \\
\hline \multirow[t]{3}{*}{ Vegetables } & $\begin{array}{l}\text { Vegetables } \\
(0-10) \\
\text { (Includes tofu and } \\
\text { soybeans) }\end{array}$ & $\begin{array}{l}\text { Root Vegetables } \\
\geq \text { Median = } 1 \\
<\text { Median }=0\end{array}$ & $\begin{array}{l}\text { Vegetables } \\
\geq \text { Median = } 1 \\
<\text { Median }=0\end{array}$ \\
\hline & & $\begin{array}{l}\text { Cabbages } \\
\geq \text { Median = } 1 \\
<\text { Median }=\end{array}$ & \\
\hline & & $\begin{array}{l}\text { Potatoes } \\
\geq \text { Median }=1 \\
<\text { Median }=0\end{array}$ & \\
\hline \multirow[t]{2}{*}{$\begin{array}{l}\text { Fruit and/or } \\
\text { nuts }\end{array}$} & $\begin{array}{l}\text { Fruits } \\
(0-10)\end{array}$ & $\begin{array}{l}\text { Nordic fruits } \\
\geq \text { Median }=1 \\
<\text { Median }=0\end{array}$ & $\begin{array}{l}\text { Includes fruit and nuts } \\
\geq \text { Median }=1 \\
<\text { Median }=0\end{array}$ \\
\hline & & $\begin{array}{l}\text { Native berries } \\
\text { (Includes "foods from } \\
\text { wild countryside") }\end{array}$ & \\
\hline \multirow[t]{2}{*}{$\begin{array}{l}\text { Cereals/Grains } \\
\text { and whole } \\
\text { grains }\end{array}$} & & $\begin{array}{l}\text { Whole grain bread } \\
\geq \text { Median }=1 \\
<\text { Median }=0\end{array}$ & $\begin{array}{l}\text { Cereals } \\
\geq \text { Median }=1 \\
<\text { Median }=0\end{array}$ \\
\hline & & $\begin{array}{l}\text { Oatmeal porridge } \\
\geq \text { Median }=1 \\
<\text { Median }=0\end{array}$ & \\
\hline Legumes & & & $\begin{array}{l}\text { Legumes } \\
\geq \text { Median }=1 \\
<\text { Median }=0\end{array}$ \\
\hline
\end{tabular}

\footnotetext{
${ }^{1}$ McCullough, M. L., Feskanich, D., Stampfer, M. J., Giovannucci, E. L., Rimm, E. B., Hu, F. B., . . Willett, W. C. (2002). Diet quality and major chronic disease risk in men and women: moving toward improved dietary guidance. Am J Clin Nutr, 76(6), 1261-1271.

2 Hillesund, E. R., Bere, E., Haugen, M., \& Overby, N. C. (2014). Development of a New Nordic Diet score and its association with gestational weight gain and fetal growth - a study performed in the Norwegian Mother and Child Cohort Study (MoBa). Public Health Nutr, 17(9), 1909-1918. doi:10.1017/S1368980014000421

${ }^{3}$ New Nordic Diet Score includes meal frequency which is not included as a component in this table ${ }^{4}$ Trichopoulou, A., Costacou, T., Bamia, C., \& Trichopoulos, D. (2003). Adherence to a Mediterranean diet and survival in a Greek population. N Engl J Med, 348(26), 2599-2608. doi:10.1056/NEJMoa025039
} 


\begin{tabular}{|c|c|c|c|}
\hline $\begin{array}{l}\text { Index/Score } \\
\text { (Reference) }\end{array}$ & $\begin{array}{l}\text { Alternate HEI-P } \\
\text { (min-max score) }^{1}\end{array}$ & $\begin{array}{l}\text { New Nordic Diet } \\
\text { Score }^{2,3}\end{array}$ & $\begin{array}{l}\text { Mediterranean Diet } \\
\text { Score }^{4}\end{array}$ \\
\hline \multirow[t]{2}{*}{ Meat } & $\begin{array}{l}\text { Ratio of white to red } \\
\text { meat } \\
(0-10)\end{array}$ & & $\begin{array}{l}\text { Meat } \\
\geq \text { Median = } 0 \\
<\text { Median }=1 \\
\text { (reverse scored) }\end{array}$ \\
\hline & & & $\begin{array}{l}\text { Poultry } \\
\geq \text { Median }=0 \\
\text { <Median }=1 \\
\text { (reverse scored) }\end{array}$ \\
\hline $\begin{array}{l}\text { Fish and other } \\
\text { protein foods }\end{array}$ & $\begin{array}{l}\text { Excluded nuts and } \\
\text { soy }\end{array}$ & $\begin{array}{l}\text { Foods from wild } \\
\text { countryside (wild fish, } \\
\text { seafood, game) } \\
\text { Also includes native } \\
\text { berries, captured as } \\
\text { part of fruits } \\
\geq \text { Median = } 1 \\
<\text { Median }=0\end{array}$ & $\begin{array}{l}\text { Fish } \\
\geq \text { Median = } 1 \\
<\text { Median }=0\end{array}$ \\
\hline Dairy & & $\begin{array}{l}\text { Milk } \\
\geq \text { Median = } 1 \\
<\text { Median = }\end{array}$ & $\begin{array}{l}\text { High fat dairy } \\
\geq \text { Median = } 0 \\
<\text { Median }=1 \\
\text { (reverse scored) }\end{array}$ \\
\hline \multirow[t]{2}{*}{ Fat } & $\begin{array}{l}\text { Trans fat } \\
(0-10) \\
\text { (reverse scored) }\end{array}$ & & $\begin{array}{l}\text { Monounsaturated: } \\
\text { Saturated fat ratio } \\
\geq \text { Median }=1 \\
<\text { Median }=0\end{array}$ \\
\hline & $\begin{array}{l}P: S^{6} \\
(0-10)\end{array}$ & & \\
\hline Fiber & $\begin{array}{l}\text { Fiber } \\
(0-10)\end{array}$ & & \\
\hline \multirow[t]{3}{*}{ Nutrients } & $\begin{array}{l}\text { Folate } \\
(0-10)\end{array}$ & & \\
\hline & $\begin{array}{l}\text { Calcium } \\
(0-10)\end{array}$ & & \\
\hline & $\begin{array}{l}\text { Iron } \\
(0-10)\end{array}$ & & \\
\hline Water & & $\begin{array}{l}\text { Water consumption } \\
\text { relative to sweetened } \\
\text { beverages } \\
\geq \text { Median }=1 \\
<\text { Median }=0\end{array}$ & \\
\hline Alcohol & Excluded alcohol & & $\begin{array}{l}\text { Alcohol } \\
5-25 \mathrm{~g} / \mathrm{d}=1\end{array}$ \\
\hline
\end{tabular}

${ }^{5}$ Salmon and trout excluded

${ }^{6}$ Ratio of polyunsaturated to saturated fat 
- Factor analysis and principal component analysis (Table 2: Summary of dietary patterns identified using factor or principal component analysis): Four studies included in this review assessed dietary patterns using factor or PCA (4-7)

- Experimental diet: The study by Khoury et al. randomly assigned participants to one of two diets:

○ Intervention diet:

- Dietitians encouraged the intake of fatty fish, vegetable oils, especially olive oil and rapeseed oil, nuts, nut butters, margarine based on olive- or rapeseed oil, and avocado to replace meat, butter, cream, and fatty dairy products; the consumption of fresh fruits and vegetables was advised (at least 6 a day); intake of dairy products in the form of skimmed or low-fat products (skimmed milk, fat-reduced cheese, and yogurt) in place of full fat products was encouraged; subjects were advised to choose meat for a main meal twice a week and use legumes, vegetable main dishes, fatty fish, or poultry with the fat trimmed off on the other days; coffee was limited to 2 cups of filtered coffee a day

- Included significantly more fish and fish products; fatty fish and fish products; rapeseed-based margarine; oils; olive oil; rapeseed oil; nuts, olives, and seeds; vegetables; and fruits, when compared to the control diet ${ }^{7}$

- Control diet:

- Subjects were asked to consume their usual diet based on Norwegian foodstuffs, and not to introduce more oils or low-fat meat and dairy products than usual

- Included significantly more fatty milk, meat and meat products, fatty minced meat, butter, and hard margarines, when compared to the intervention $\operatorname{diet}^{5}$

\section{Time point of exposure (Table 3: Time point of exposure assessment):}

As outlined below, the time period of data collection was variable:

- Khoury et al. assigned participants to an intervention or control diet at baseline between 17-20 weeks gestation

- Four studies collected dietary data from women during their second trimester (between $\sim 20$ and 22 weeks) $(2,4,5,8)$

- Timmermans et al. collected food frequency questionnaire (FFQ) data during early pregnancy (median 13.5 weeks) and measured the outcomes at multiple time points (early-, mid- and late-pregnancy). The body of evidence included outcomes from mid and late pregnancy from this study.

- Rifas-Shiman et al. gathered dietary data at two times $(11.7 \pm 3.1$ weeks and 26 28 weeks). However, data from the first trimester, alone, are included in this

\footnotetext{
${ }^{7}$ Khoury, J., Henriksen, T., Seljeflot, I., Mørkrid, L., Frøslie, K. F., \& Tonstad, S. (2007). Effects of an antiatherogenic diet during pregnancy on markers of maternal and fetal endothelial activation and inflammation: the CARRDIP study. BJOG, 114(3), 279-288. doi:10.1111/j.1471-0528.2006.01187.x
} 
body of evidence. Dietary data from 26 to 28 weeks are excluded due to temporality issues.

- The dietary recall data generally reflected women's diet starting from periconception to until when the dietary data were collected. Two studies used data from the Australian Longitudinal Study on Women's Health (ALSWH) that included preconception dietary data collected 3,6 or 9 years prior to the outcome ascertainment in their analyses $(3,7)$. 
Table 2: Summary of dietary patterns identified using factor or principal component analysis

\begin{tabular}{|c|c|}
\hline Articles & Dietary Patterns \\
\hline Brantsæter, 2009 & $\begin{array}{l}\text { Cakes and sweets pattern: High loadings on cakes, waffles and pancakes, buns, ice cream, } \\
\text { sweet biscuits, sweets, and chocolate }\end{array}$ \\
\hline Torjusen, 2014 & $\begin{array}{l}\text { Health and sustainability pattern: High positive loadings for vegetables, fruit and berries, cooking } \\
\text { oil, olive oil, and whole grain products; negative loadings for meat, including processed meat, white } \\
\text { bread, salty snacks, pommes frites and cakes and sweets }\end{array}$ \\
\hline Timmermans, 2011 & $\begin{array}{l}\text { Traditional pattern: High intake of meat and potatoes, and low intake of fruit, nonalcoholic drinks, } \\
\text { fish, and bread }\end{array}$ \\
\hline \multirow[t]{4}{*}{ Schoenaker, 2015} & $\begin{array}{l}\text { Meat, high-fat, and sugar pattern: Characterized by high consumption of meat, processed meat, } \\
\text { cakes, sweet biscuits, chocolate, meat pies, and pizza }\end{array}$ \\
\hline & $\begin{array}{l}\text { Mediterranean-style pattern: Characterized by high consumption of vegetables, legumes, nuts, } \\
\text { tofu, rice, pasta, rye bread, red wine, and fish }\end{array}$ \\
\hline & $\begin{array}{l}\text { Fruit and low-fat dairy pattern: Characterized by high consumption of fruit, yogurt, low-fat cheese, } \\
\text { and skim milk }\end{array}$ \\
\hline & $\begin{array}{l}\text { Cooked vegetable pattern: Characterized by high consumption of carrots, peas, cooked potatoes, } \\
\text { cauliflower, and pumpkin }\end{array}$ \\
\hline
\end{tabular}




\section{Table 3: Time point of exposure assessment}

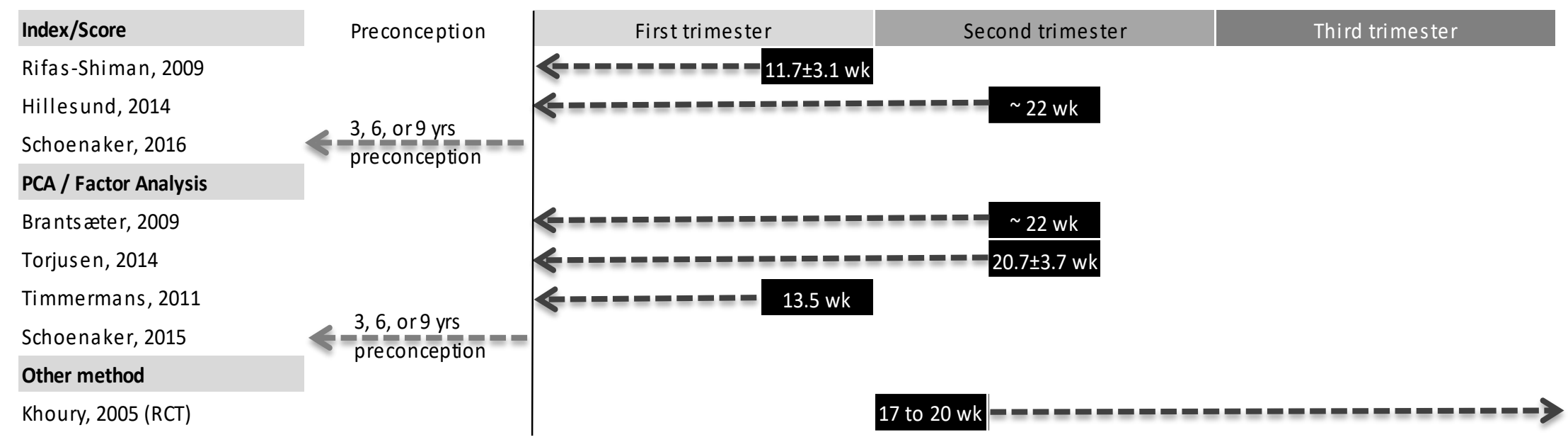




\section{Outcomes:}

Studies assessed HDP (including preeclampsia, early preeclampsia and gestational hypertension) and blood pressure as outcomes. Table 4: Summary of outcome definitions summarizes the outcomes and diagnostic criteria grouped by methodology used to create dietary patterns.

Table 4: Summary of outcome definitions

\begin{tabular}{|c|c|c|c|c|c|c|}
\hline Study & Outcome & $\begin{array}{l}\text { Diagnostic } \\
\text { Criteria }\end{array}$ & $\begin{array}{l}\text { Source of } \\
\text { Criteria }\end{array}$ & Method of Assessment & References & $\begin{array}{l}\text { Additional } \\
\text { Outcomes }\end{array}$ \\
\hline \multicolumn{7}{|l|}{ Index/Score } \\
\hline $\begin{array}{l}\text { Rifas- } \\
\text { Shiman, } 2009\end{array}$ & Preeclampsia & $\begin{array}{l}\text { Increased blood } \\
\text { pressure and } \\
\text { proteinuria (dip- } \\
\text { stick value of } 1+\text { on } \\
\text { two or more } \\
\text { occasions or } \geq 2+ \\
\text { once) }>4 \text { hours but } \\
\leq 7 \text { days apart OR } \\
\text { chronic } \\
\text { hypertension and } \\
\text { developed } \\
\text { proteinuria after } 20 \\
\text { weeks' gestation }\end{array}$ & $\begin{array}{l}\text { National } \\
\text { High Blood } \\
\text { Pressure } \\
\text { Education } \\
\text { Program }\end{array}$ & $\begin{array}{l}\text { Clinical blood pressure } \\
\text { and urine protein } \\
\text { measurements }\end{array}$ & $\begin{array}{l}\text { Gifford, } \\
2000^{11}\end{array}$ & $\begin{array}{l}\text { Birth weight } \\
\text { for } \\
\text { gestational } \\
\text { age } \\
\text { Impaired } \\
\text { glucose } \\
\text { tolerance \& } \\
\text { gestational } \\
\text { diabetes } \\
\text { Gestational } \\
\text { weight gain }\end{array}$ \\
\hline
\end{tabular}

${ }^{11}$ Gifford, R. W. (2000). Report of the National High Blood Pressure Education Program Working Group on High Blood Pressure in Pregnancy. Am J Obstet Gynecol, 183(1), S1-S22. 


\begin{tabular}{|c|c|c|c|c|c|c|}
\hline Study & Outcome & $\begin{array}{l}\text { Diagnostic } \\
\text { Criteria }\end{array}$ & $\begin{array}{l}\text { Source of } \\
\text { Criteria }\end{array}$ & Method of Assessment & References & $\begin{array}{l}\text { Additional } \\
\text { Outcomes }\end{array}$ \\
\hline \multirow[t]{2}{*}{$\begin{array}{l}\text { Hillesund, } \\
2014\end{array}$} & $\begin{array}{l}\text { Preeclampsia; } \\
\text { Early } \\
\text { preeclampsia }\end{array}$ & $\begin{array}{l}\text { Increase in blood } \\
\text { pressure to } \geq 140 \\
\mathrm{~mm} \mathrm{Hg} \text { systolic or } \\
90 \mathrm{~mm} \text { Hg diastolic, } \\
\text { after the } 20 \text { th } \\
\text { gestational week, } \\
\text { combined with } \\
\text { proteinuria (protein } \\
\text { excretion of at least } \\
0.3 \text { g/24 h or } \geq 1+ \\
\text { on a dip-stick } \\
\text { assay), both } \\
\text { measured at least } \\
\text { twice }\end{array}$ & $\begin{array}{l}\text { Norwegian } \\
\text { Federation } \\
\text { of } \\
\text { Obstetrician } \\
\text { s and } \\
\text { Gynecologis } \\
\text { ts }\end{array}$ & $\begin{array}{l}\text { Obtained from Medical } \\
\text { Birth Registry of Norway, } \\
\text { which is based on forms } \\
\text { completed by midwives } \\
\text { after birth by checking } \\
\text { one or more of the } \\
\text { following: 'Preeclampsia, } \\
\text { mild', 'Preeclampsia, } \\
\text { severe', 'Preeclampsia, } \\
\text { before } 34 \text { weeks', } \\
\text { 'Eclampsia', 'Gestational } \\
\text { hypertension (without } \\
\text { proteinuria)', and 'Pre- } \\
\text { existing hypertension' }\end{array}$ & $\begin{array}{l}\text { Klungsøyr, } \\
2012^{12}\end{array}$ & $\begin{array}{l}\text { Gestational } \\
\text { age }\end{array}$ \\
\hline & & $\begin{array}{l}\text { Early preeclampsia } \\
\text { diagnosed before } \\
34 \text { weeks gestation }\end{array}$ & & $\begin{array}{l}\text { In present study, } \\
\text { preeclampsia cases } \\
\text { included reported } \\
\text { preeclampsia, eclampsia, } \\
\text { a combination of } \\
\text { hemolysis, elevated liver } \\
\text { enzymes, low platelet } \\
\text { count (HELLP } \\
\text { syndrome), and } \\
\text { preeclampsia } \\
\text { superimposed on chronic } \\
\text { hypertension }\end{array}$ & & \\
\hline
\end{tabular}

12 Klungsoyr, K., Morken, N. H., Irgens, L., Vollset, S. E., \& Skjaerven, R. (2012). Secular trends in the epidemiology of pre-eclampsia throughout 40 years in Norway: prevalence, risk factors and perinatal survival. Paediatr Perinat Epidemiol, 26(3), 190-198. doi:10.1111/j.1365-3016.2012.01260.x 


\begin{tabular}{|c|c|c|c|c|c|c|}
\hline Study & Outcome & $\begin{array}{l}\text { Diagnostic } \\
\text { Criteria }\end{array}$ & $\begin{array}{l}\text { Source of } \\
\text { Criteria }\end{array}$ & Method of Assessment & References & $\begin{array}{l}\text { Additional } \\
\text { Outcomes }\end{array}$ \\
\hline $\begin{array}{l}\text { Schoenaker, } \\
2016\end{array}$ & $\begin{array}{l}\text { Hypertensive } \\
\text { disorders of } \\
\text { pregnancy }\end{array}$ & $\begin{array}{l}\text { Gestational } \\
\text { hypertension } \\
\text { defined as new- } \\
\text { onset hypertension } \\
\text { after } 20 \text { wk of } \\
\text { gestation with } \geq 140 \\
\mathrm{~mm} \mathrm{HG} \text { systolic or } \\
\geq 90 \mathrm{~mm} \mathrm{Hg} \\
\text { diastolic blood } \\
\text { pressure; } \\
\text { Preeclampsia } \\
\text { defined as } \\
\text { gestational } \\
\text { hypertension with } \\
\text { involvement of } \geq 1 \\
\text { other organ } \\
\text { systems and/or the } \\
\text { fetus }\end{array}$ & NR & $\begin{array}{l}\text { Self-reported physician } \\
\text { diagnosis in response to } \\
\text { question, "Were you } \\
\text { diagnosed or treated for } \\
\text { hypertension (high blood } \\
\text { pressure) during } \\
\text { pregnancy?" }\end{array}$ & $\begin{array}{l}\text { Lowe, } \\
\text { 2009 } \\
\text { Gresham, } \\
2015^{14}\end{array}$ & $\begin{array}{l}\text { Gestational } \\
\text { diabetes }\end{array}$ \\
\hline
\end{tabular}

\section{PCA/Factor}

Analysis

\footnotetext{
${ }^{13}$ Lowe, S. A., Brown, M. A., Dekker, G. A., Gatt, S., McLintock, C. K., McMahon, L. P., . . Walters, B. (2009). Guidelines for the management of hypertensive disorders of pregnancy 2008. Aust N Z J Obstet Gynaecol, 49(3), 242-246. doi:10.1111/j.1479-828X.2009.01003.x

${ }_{14}$ Gresham, E., Forder, P., Chojenta, C. L., Byles, J. E., Loxton, D. J., \& Hure, A. J. (2015). Agreement between self-reported perinatal outcomes and administrative data in New South Wales, Australia. BMC Pregnancy and Childbirth, 15(1), 161. doi:10.1186/s12884-015-0597-x
} 


\begin{tabular}{|c|c|c|c|c|c|c|}
\hline Study & Outcome & $\begin{array}{l}\text { Diagnostic } \\
\text { Criteria }\end{array}$ & $\begin{array}{l}\text { Source of } \\
\text { Criteria }\end{array}$ & Method of Assessment & References & $\begin{array}{l}\text { Additional } \\
\text { Outcomes }\end{array}$ \\
\hline $\begin{array}{l}\text { Brantsæter, } \\
2009\end{array}$ & Preeclampsia & $\begin{array}{l}\text { Blood pressure } \\
>140 / 90 \text { after } 20 \\
\text { weeks of gestation, } \\
\text { combined with } \\
\text { proteinuria }>+1 \\
\text { dipstick on at least } \\
2 \text { occasions }\end{array}$ & $\begin{array}{l}\text { Society for } \\
\text { Gynecology }\end{array}$ & $\begin{array}{l}\text { Obtained from Medical } \\
\text { Birth Registry of Norway; } \\
\text { registry is based on } \\
\text { forms completed by } \\
\text { midwives with } 5 \text { check-off } \\
\text { boxes relevant to pre- } \\
\text { eclampsia: haemolysis, } \\
\text { elevated liver enzymes } \\
\text { and low platelet count } \\
\text { (HELLP syndrome); } \\
\text { eclampsia; early pre- } \\
\text { eclampsia (diagnosed } \\
\text { before } 34 \text { weeks); mild } \\
\text { pre-eclampsia and } \\
\text { severe pre-eclampsia } \\
\text { Diagnosis of } \\
\text { preeclampsia given if any } \\
\text { of the aforementioned } \\
\text { diagnoses were present }\end{array}$ & $\begin{array}{l}\text { Norwegian } \\
\text { Medical } \\
\text { Association, } \\
2006^{15}\end{array}$ & $N / A$ \\
\hline
\end{tabular}

${ }^{15}$ Norwegian Medical Association - The Norwegian Society of Obstetrics and Gynecology. (2006). Clinical guidelines in obstetrics. Retrieved from www.legeforeningen.no/id/78144.0 


\begin{tabular}{|c|c|c|c|c|c|c|}
\hline Study & Outcome & $\begin{array}{l}\text { Diagnostic } \\
\text { Criteria }\end{array}$ & $\begin{array}{l}\text { Source of } \\
\text { Criteria }\end{array}$ & Method of Assessment & References & $\begin{array}{l}\text { Additional } \\
\text { Outcomes }\end{array}$ \\
\hline $\begin{array}{l}\text { Torjusen, } \\
2014\end{array}$ & Preeclampsia & $\begin{array}{l}\text { Blood pressure } \\
>140 / 90 \text { after } 20 \\
\text { weeks of gestation, } \\
\text { combined with } \\
\text { proteinuria }>+1 \\
\text { dipstick on at least } \\
2 \text { occasions }\end{array}$ & $\begin{array}{l}\text { Society for } \\
\text { Gynecology }\end{array}$ & $\begin{array}{l}\text { Obtained from Medical } \\
\text { Birth Registry of Norway; } \\
\text { registry is based on } \\
\text { forms completed by } \\
\text { midwives with } 5 \text { check-off } \\
\text { boxes relevant to pre- } \\
\text { eclampsia: haemolysis, } \\
\text { elevated liver enzymes } \\
\text { and low platelet count } \\
\text { (HELLP syndrome); } \\
\text { eclampsia; early pre- } \\
\text { eclampsia (diagnosed } \\
\text { before } 34 \text { weeks); mild } \\
\text { pre-eclampsia and } \\
\text { severe pre-eclampsia } \\
\text { Diagnosis of } \\
\text { preeclampsia given if any } \\
\text { of the aforementioned } \\
\text { diagnoses were present }\end{array}$ & $\begin{array}{l}\text { Irgens, } \\
2000^{16} \\
\text { Thomsen, } \\
2013^{17}\end{array}$ & $\begin{array}{l}\text { Gestational } \\
\text { weight gain }\end{array}$ \\
\hline
\end{tabular}

${ }^{16}$ Irgens, L. M. (2000). The Medical Birth Registry of Norway. Epidemiological research and surveillance throughout 30 years. Acta Obstet Gynecol Scand, 79(6), 435-439.

17 Thomsen, L. C., Klungsoyr, K., Roten, L. T., Tappert, C., Araya, E., Baerheim, G., . . Bjorge, L. (2013). Validity of the diagnosis of pre-eclampsia in the Medical Birth Registry of Norway. Acta Obstet Gynecol Scand, 92(8), 943-950. doi:10.1111/aogs.12159 


\begin{tabular}{|c|c|c|c|c|c|c|}
\hline Study & Outcome & $\begin{array}{l}\text { Diagnostic } \\
\text { Criteria }\end{array}$ & $\begin{array}{l}\text { Source of } \\
\text { Criteria }\end{array}$ & Method of Assessment & References & $\begin{array}{l}\text { Additional } \\
\text { Outcomes }\end{array}$ \\
\hline \multirow[t]{2}{*}{$\begin{array}{l}\text { Timmermans, } \\
2011\end{array}$} & \multirow[t]{2}{*}{$\begin{array}{l}\text { Maternal } \\
\text { blood } \\
\text { pressure; } \\
\text { Gestational } \\
\text { hypertension; } \\
\text { Preeclampsia }\end{array}$} & $\begin{array}{l}\text { Gestational } \\
\text { hypertension } \\
\text { defined as new- } \\
\text { onset hypertension } \\
\text { (SBP } \geq 140 \mathrm{~mm} \mathrm{HG} \\
\text { and/or DBP } \geq 90 \\
\mathrm{~mm} \mathrm{Hg}>20 \mathrm{wk} \\
\text { gestation in } \\
\text { previously } \\
\text { normotensive } \\
\text { woman on at least } \\
2 \text { occassions) }\end{array}$ & \multirow[t]{2}{*}{$\begin{array}{l}\text { International } \\
\text { Society for } \\
\text { the Study of } \\
\text { Hypertensio } \\
n \text { in } \\
\text { Pregnancy }\end{array}$} & \multirow[t]{2}{*}{$\begin{array}{l}\text { SBP and DBP: validated } \\
\text { Omron } 907 \text { automated } \\
\text { digital oscillometric } \\
\text { sphygmomanometer } \\
\text { Doctor-diagnosed } \\
\text { gestational hypertension } \\
\text { and preeclampsia } \\
\text { retrieved from medical } \\
\text { records }\end{array}$} & \multirow[t]{2}{*}{$\begin{array}{l}\text { Brown, } \\
2001^{18} \\
\text { Coolman, } \\
2010^{19}\end{array}$} & \multirow[t]{2}{*}{$\mathrm{N} / \mathrm{A}$} \\
\hline & & $\begin{array}{l}\text { Preeclampsia } \\
\text { defined as } \\
\text { gestational } \\
\text { hypertension with } \\
\text { proteinuria ( } \geq 2 \\
\text { dipstick readings of } \\
\geq 2+, \geq 1 \text { sample } \\
\text { reading of } 1+, \text { or } \\
24 \text {-hour urine } \\
\text { collection } \\
\text { containing at least } \\
300 \text { mg of protein) }\end{array}$ & & & & \\
\hline
\end{tabular}

${ }^{18}$ Brown, M. A., Lindheimer, M. D., de Swiet, M., Van Assche, A., \& Moutquin, J. M. (2001). The classification and diagnosis of the hypertensive disorders of pregnancy: statement from the International Society for the Study of Hypertension in Pregnancy (ISSHP). Hypertens Pregnancy, 20(1), Ix-xiv. doi:10.1081/prg-100104165

${ }_{19}$ Coolman, M., de Groot, C. J., Jaddoe, V. W., Hofman, A., Raat, H., \& Steegers, E. A. (2010). Medical record validation of maternally reported history of preeclampsia. J Clin Epidemiol, 63(8), 932-937. doi:10.1016/j.jclinepi.2009.10.010 


\begin{tabular}{|c|c|c|c|c|c|c|}
\hline Study & Outcome & $\begin{array}{l}\text { Diagnostic } \\
\text { Criteria }\end{array}$ & $\begin{array}{l}\text { Source of } \\
\text { Criteria }\end{array}$ & Method of Assessment & References & $\begin{array}{l}\text { Additional } \\
\text { Outcomes }\end{array}$ \\
\hline $\begin{array}{l}\text { Schoenaker, } \\
2015\end{array}$ & $\begin{array}{l}\text { Hypertensive } \\
\text { disorders of } \\
\text { pregnancy }\end{array}$ & $\begin{array}{l}\text { Gestational } \\
\text { hypertension } \\
\text { defined as new- } \\
\text { onset hypertension } \\
\text { after } 20 \text { wk of } \\
\text { gestation with } \geq 140 \\
\text { mm HG systolic or } \\
\geq 90 \mathrm{~mm} \mathrm{Hg} \\
\text { diastolic blood } \\
\text { pressure; } \\
\text { Preeclampsia } \\
\text { defined as } \\
\text { gestational } \\
\text { hypertension with } \\
\text { involvement of } \geq 1 \\
\text { other organ } \\
\text { systems and/or the } \\
\text { fetus }\end{array}$ & NR & $\begin{array}{l}\text { Self-reported physician } \\
\text { diagnosis in response to } \\
\text { question, "Were you } \\
\text { diagnosed or treated for } \\
\text { hypertension (high blood } \\
\text { pressure) during } \\
\text { pregnancy?" }\end{array}$ & $\begin{array}{l}\text { Lowe, } \\
\text { 200920; } \\
\text { Gresham, } \\
2015^{21}\end{array}$ & $\mathrm{~N} / \mathrm{A}$ \\
\hline
\end{tabular}

\section{Other Method}

\footnotetext{
${ }^{20}$ Lowe, S. A., Brown, M. A., Dekker, G. A., Gatt, S., McLintock, C. K., McMahon, L. P., . . Walters, B. (2009). Guidelines for the management of hypertensive disorders of pregnancy 2008. Aust N Z J Obstet Gynaecol, 49(3), 242-246. doi:10.1111/j.1479-828X.2009.01003.X

${ }^{21}$ Gresham, E., Forder, P., Chojenta, C., Byles, J., Loxton, D., \& Hure, A. (2015). [Personal communication].
} 


\begin{tabular}{|c|c|c|c|c|c|c|}
\hline Study & Outcome & $\begin{array}{l}\text { Diagnostic } \\
\text { Criteria }\end{array}$ & $\begin{array}{l}\text { Source of } \\
\text { Criteria }\end{array}$ & Method of Assessment & References & $\begin{array}{l}\text { Additional } \\
\text { Outcomes }\end{array}$ \\
\hline Khoury, 2005 & $\begin{array}{l}\text { Hypertensive } \\
\text { disorders of } \\
\text { pregnancy }^{22}\end{array}$ & $\begin{array}{l}\text { Pregnancy-induced } \\
\text { hypertension: } \\
\text { [blood pressure } \\
>140 / 90 \mathrm{mmHg} \\
\text { after gestational } \\
\text { week } 20 \text { measured } \\
\text { at } 2 \text { occassions at } \\
\text { least } 6 \text { hours apart] } \\
\text { with } 1+\text { proteinuria } \\
\text { on a dipstick assay } \\
\text { [preeclampsia] or } \\
\text { without proteinuria }\end{array}$ & NR & $\begin{array}{l}\text { Data obtained from } \\
\text { hospital records }\end{array}$ & $\mathrm{N} / \mathrm{A}$ & $\begin{array}{l}\text { Preterm } \\
\text { delivery } \\
\text { IUGR } \\
\text { Fetal } \\
\text { distress } \\
\text { Birth weight } \\
\text { Gestational } \\
\text { age }\end{array}$ \\
\hline
\end{tabular}

${ }^{22}$ Addressed by the authors as "hypertensive complications" 


\section{Evidence synthesis}

With 8 included studies from 1 trial and 4 cohorts, there is a small body of evidence available to examine the relationship between dietary patterns and risk of HDP. There is substantial heterogeneity in methodology employed to define and assess dietary patterns, which makes it difficult to compare findings across studies. Despite the variability, 5 of the 8 included studies reported significant relationships between dietary patterns and HDP risk (Table 5: Results grouped by methodology used for dietary pattern assessment). An additional study showed an association between dietary patterns and blood pressure, but not preeclampsia or gestational hypertension.

\section{Dietary patterns assessed via index/score}

Three studies used indices/scores to assess dietary patterns. Two of these studies noted a significant relationship between dietary patterns and $\operatorname{HDP}(2,3)$.

Schoenaker et al. assessed HDP in relation to a Mediterranean diet (3). Beneficial foods included vegetables, legumes, fruit and nuts, cereals, fish, and monounsaturated:saturated fat ratio, and detrimental foods included meat, poultry, and high-fat dairy. Compared to high adherence, lower adherence to the Mediterranean diet was associated with an increased odds of HDP.

Hillesund et al. assessed adherence to the New Nordic Diet, which measures the frequency of eating the following foods: Nordic fruits (apples, pears, plums, strawberries), root vegetables (carrots, rutabaga and various types of onions), cabbages (kale, cauliflower, broccoli and Brussels sprouts), potatoes, whole grain breads, oat meal porridge, foods from the wild countryside (wild fish, seafood, game and wild berries), milk and water (2). High adherence was associated with a reduced odds of both preeclampsia and early preeclampsia.

The third study did not find a significant association between maternal diet and HDP (1). This study was conducted in the U.S. Project Viva cohort, and measured adherence to the Alternate Healthy Eating Index for Pregnancy (AHEI-P), which considered vegetables, fruit, ratio of white to red meat, fiber, trans fat, ratio of polyunsaturated to saturated fatty acids, and folate, calcium, and iron from foods. The outcome of interest was preeclampsia. The odds of preeclampsia for each 5-point increase in AHEI-P score were not statistically significant.

The differences across studies in the index/score measured limits the ability to compare findings. However, the overall direction of association between types of food and amount of HDP risk was consistent across studies, including the one that reported non-statistically significant findings.

\section{Dietary patterns assessed via factor or principal component analysis}

Studies using data-driven methods to identify dietary patterns (i.e., principal component analysis or exploratory factor analysis) noted associations between high vegetable and Mediterranean-type dietary patterns and lower risk of HDP. The findings from Brantsæter et al. showed that greater adherence to a Vegetable dietary pattern (characterized by positive loadings for vegetables, cooking oil, olive oil, fruits and berries, rice, and chicken) reduced the odds of developing preeclampsia, while greater adherence to the Processed Food dietary pattern (characterized by positive loadings for meat products, white bread, French fries, salty snacks, and sugar-sweetened beverages; and negative loadings on oily fish, high-fiber cereals, and lean fish) 
increased the odds of preeclampsia (4). Similarly, Torjusen et al. found that a dietary pattern with high loadings for vegetables, fruit and berries, cooking oil, olive oil, and whole grain products and negative loadings for meat, including processed meat, white bread, salty snacks, pommes frites and cakes and sweets were associated with lower risk of preeclampsia (5).

Studies examining associations between a Mediterranean-type diet and HDP risk showed mixed findings. Schoenaker et al. observed greater adherence to a dietary pattern characterized by high consumption of vegetables, legumes, nuts, tofu, rice, pasta, rye bread, red wine, and fish was associated with lower HDP risk (7). Conversely, Timmermans et al. reported that while a diet characterized by high consumption of high intake of vegetables, vegetable oils, pasta, rice, fish, and legumes, moderate intake of alcohol, and low intake of sweets was associated with lower maternal blood pressure during pregnancy, there was no significant association between consumption of this dietary pattern and HDP (6). Timmermans et al. also noted that high adherence to a traditional dietary pattern characterized by high intake of meat and potatoes, and low intake of fruit, nonalcoholic drinks, fish, and bread was associated with higher maternal blood pressure during pregnancy.

\section{Dietary patterns assessed in the RCT}

In the RCT, participants randomized to the intervention consumed a diet characterized by higher amounts of fruits and vegetables, fatty fish, vegetable oils, nuts and low-fat dairy. Participants were also asked to restrict meat and replace it with avocado, as well as to limit coffee consumption to 2 cups/day. Subjects who were assigned to the control group were asked to consume their usual diet based on Norwegian foodstuffs and to not introduce more oils or low-fat meat and dairy products than usual.

The only RCT in this body of evidence reported no significant difference in the incidence of HDP (addressed by the authors as "hypertensive complications") among those randomized to intervention vs. control diets. (8). It should be noted that the RCT was conducted among 240 women and was not powered to examine the outcome of interest. It is also likely that the timing of the intervention in the RCT may have been too late in pregnancy to have seen an effect.

\section{Summary}

Overall, these findings show some consistency in the patterns of dietary consumption during early pregnancy that are associated with reduced risk of HDP. However, because of heterogeneity in methods, the dietary patterns vary considerably across studies, limiting direct comparison. Furthermore, three of these studies assessed diet in mid-pregnancy and represent consumption during either early pregnancy $(4,5)$ or the three months prior to conception and early pregnancy (6). Additionally, the fourth study measured dietary intake over the previous years, and the amount of time between this measurement and the actual pregnancy may have varied substantially across participants (7). Study participants in the RCT, on the other hand, followed the diet starting mid-pregnancy (17-20 weeks gestation) until delivery (8), which for outcomes such as gestational hypertension may not have been sufficient time for an effect to take place. Therefore, the impact on the outcome being positive across studies is informative, but there are substantial methodological and measurement issues that limit the ability to compare findings across this body of literature. 
Table 5. Results grouped by methodology used for dietary pattern assessment

\begin{tabular}{|l|}
\hline Key for color-coding: \\
\hline Dietary pattern categorized as beneficial when... \\
Greater adherence reduces risk of HDP \\
Lower adherence increases risk of HDP \\
Dietary pattern categorized as detrimental when... \\
Greater adherence increases risk of HDP \\
Lower adherence decreases risk of HDP \\
\hline
\end{tabular}

Table 5: Results grouped by methodology used for dietary pattern assessment

\begin{tabular}{|c|c|c|c|c|}
\hline $\begin{array}{l}\text { Author, Year } \\
\text { Country, N }\end{array}$ & Exposure & Outcome & Significant finding & NS finding \\
\hline \multicolumn{5}{|l|}{ Index/Score } \\
\hline Rifas-Shiman, 2009 & AHEI-P & Preeclampsia & & First trimester: \\
\hline $\begin{array}{l}\text { USA } \\
N=1,777\left(1^{\text {st }}\right. \\
\text { trimester) }\end{array}$ & $\begin{array}{l}\text { vegetables; fruit; ratio of white to red } \\
\text { meat; fiber; trans fat; ratio of } \\
\text { polyunsaturated to saturated fatty } \\
\text { acids; and folate, calcium, and iron from } \\
\text { foods }\end{array}$ & $\begin{array}{l}\text { (OR - for } \\
\text { each 5-point } \\
\text { increase in } \\
\text { AHEI-P } \\
\text { score) }\end{array}$ & & $\begin{array}{l}0.96 \\
(95 \% \mathrm{Cl}: 0.84,1.10)\end{array}$ \\
\hline
\end{tabular}




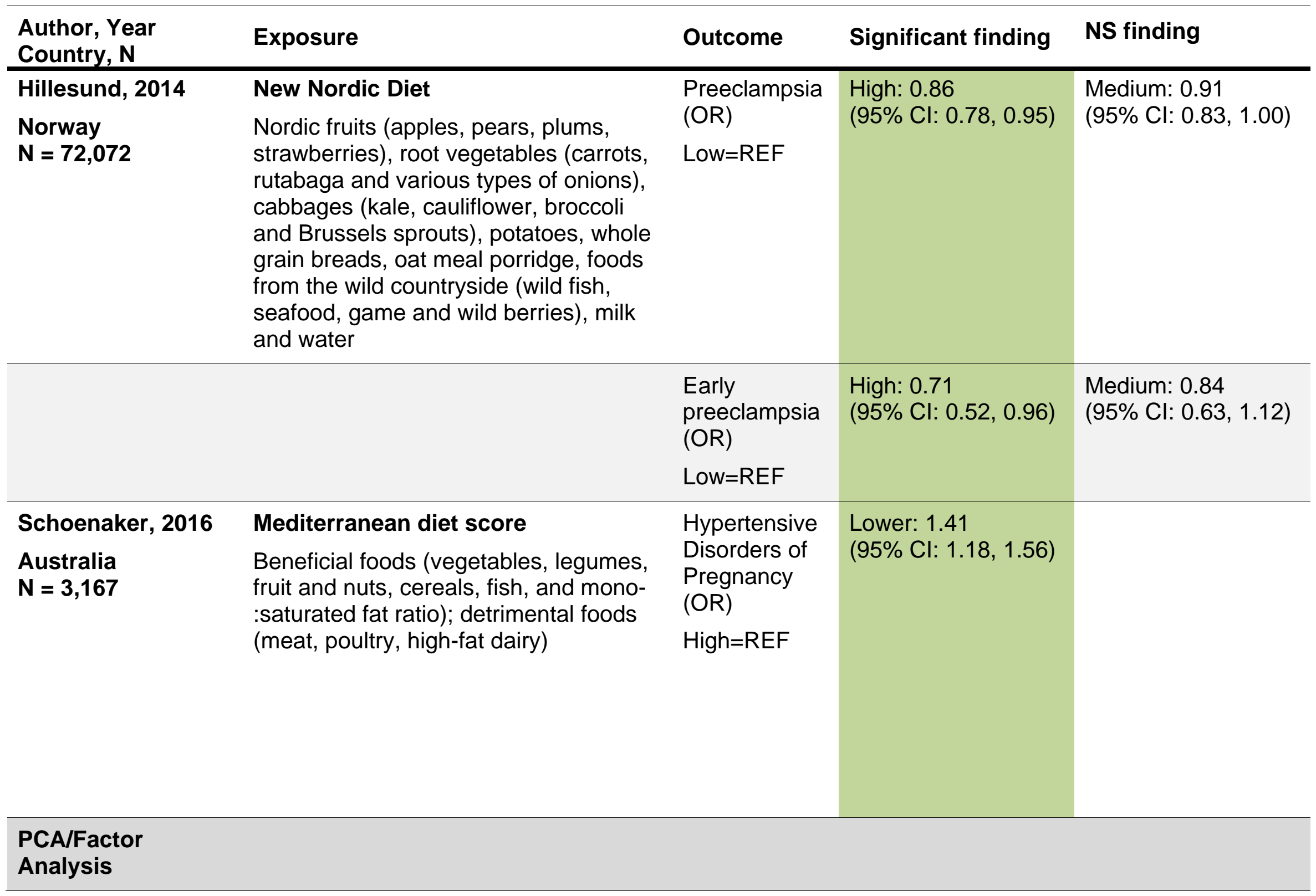




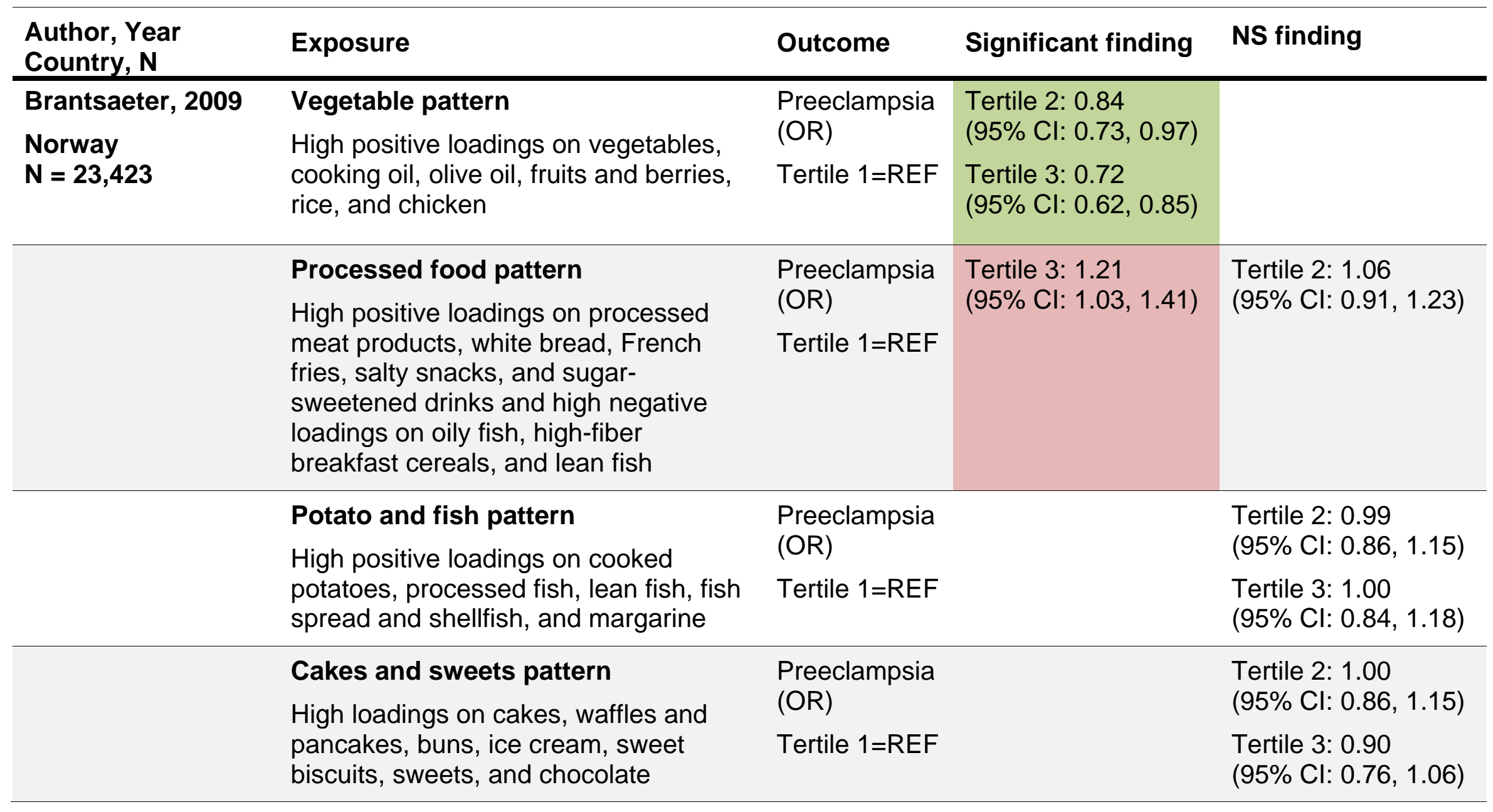




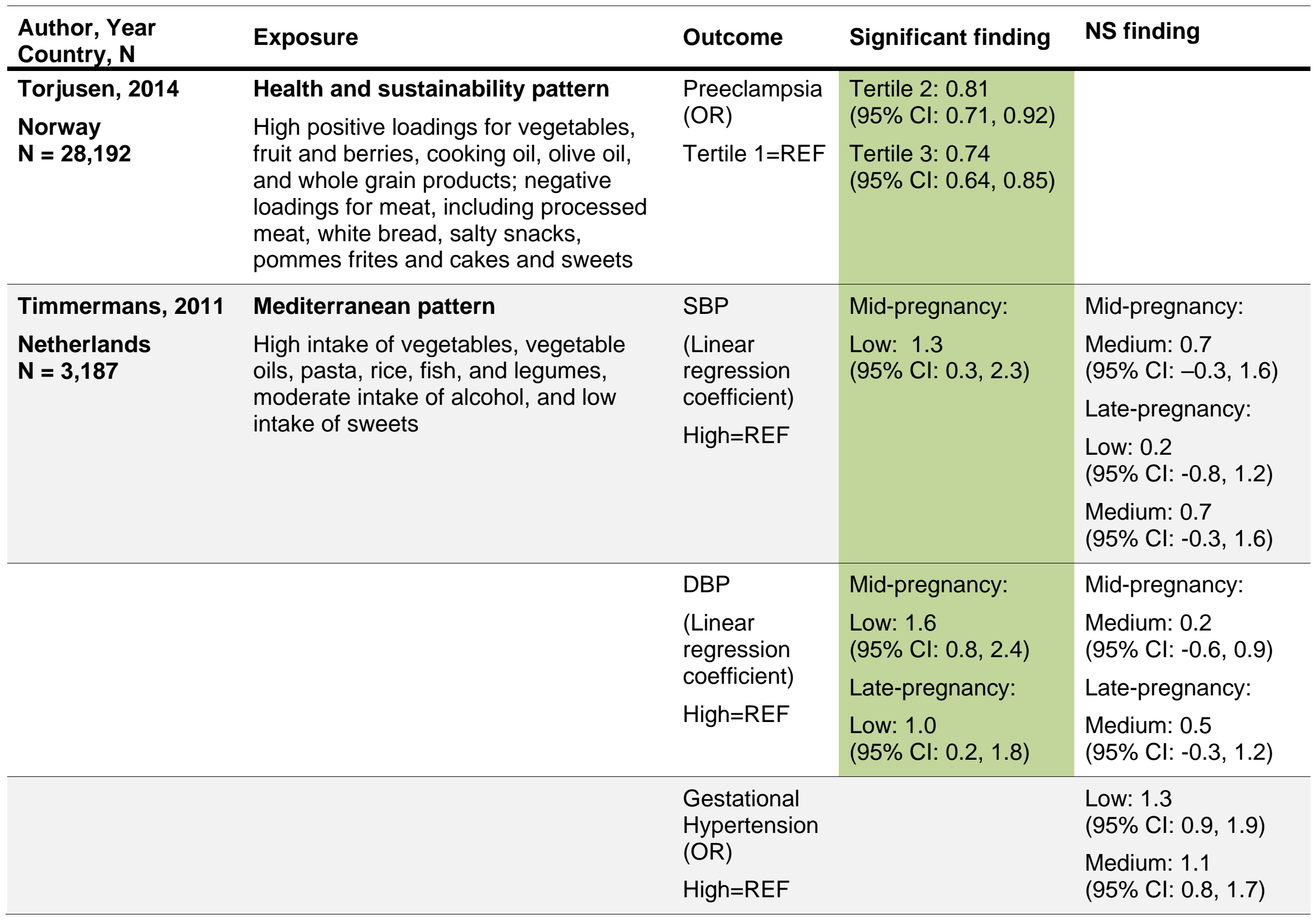




\begin{tabular}{|c|c|c|c|c|}
\hline $\begin{array}{l}\text { Author, Year } \\
\text { Country, N }\end{array}$ & Exposure & Outcome & Significant finding & NS finding \\
\hline & \multirow{8}{*}{$\begin{array}{l}\text { Traditional pattern } \\
\text { High intake of meat and potatoes, and } \\
\text { low intake of fruit, nonalcoholic drinks, } \\
\text { fish, and bread }\end{array}$} & \multicolumn{2}{|l|}{$\begin{array}{l}\text { Preeclampsia } \\
\text { (OR) }\end{array}$} & $\begin{array}{l}\text { Low: } 1.2 \\
(95 \% \mathrm{Cl}: 0.6,2.3)\end{array}$ \\
\hline & & \multicolumn{2}{|l|}{ High=REF } & $\begin{array}{l}\text { Medium: } 1.2 \\
(95 \% \mathrm{Cl}: 0.6,2.3)\end{array}$ \\
\hline & & \multirow{3}{*}{$\begin{array}{l}\text { SBP } \\
\text { (Linear } \\
\text { regression } \\
\text { coefficient) }\end{array}$} & \multirow{2}{*}{$\begin{array}{l}\text { Mid-pregnancy: } \\
\text { Medium: } 1.3 \\
(95 \% \text { Cl: } 0.4,2.3)\end{array}$} & Late-pregnancy: \\
\hline & & & & $\begin{array}{l}\text { Medium: } 0.7 \\
(95 \% \mathrm{Cl}:-0.3,1.6)\end{array}$ \\
\hline & & & \multirow{2}{*}{$\begin{array}{l}\text { High: } 2.3 \\
\text { (95\% Cl: } 1.2,3.3)\end{array}$} & \\
\hline & & \multirow[t]{3}{*}{ Low=REF } & & \\
\hline & & & Late-pregnancy: & \\
\hline & & & $\begin{array}{l}\text { High: } 2.6 \\
(95 \% \text { Cl: } 1.6,3.6)\end{array}$ & \\
\hline & & DBP & Mid-pregnancy: & Late-pregnancy: \\
\hline & & \multirow{2}{*}{$\begin{array}{l}\text { (Linear } \\
\text { regression } \\
\text { coefficient) }\end{array}$} & $\begin{array}{l}\text { Medium: } 0.9 \\
(95 \% \mathrm{Cl}: 0.1,1.7)\end{array}$ & \multirow[t]{5}{*}{$\begin{array}{l}\text { Medium: } 0.3 \\
(95 \% \mathrm{Cl}:-0.4,1.1)\end{array}$} \\
\hline & & & High: 1.3 & \\
\hline & & \multirow[t]{3}{*}{ Low=REF } & (95\% Cl: $0.5,2.1)$ & \\
\hline & & & Late-pregnancy: & \\
\hline & & & $\begin{array}{l}\text { High: } 0.8 \\
(95 \% \text { Cl: } 0.1,1.6)\end{array}$ & \\
\hline & & \multirow{2}{*}{\multicolumn{2}{|c|}{$\begin{array}{l}\text { Gestational } \\
\text { Hypertension } \\
(\text { OR) }\end{array}$}} & $\begin{array}{l}\text { Medium: } 1.0 \\
(95 \% \mathrm{Cl}: 0.7,1.6)\end{array}$ \\
\hline & & & & High: 1.3 \\
\hline & & \multicolumn{2}{|l|}{ Low=REF } & (95\% Cl: 0.9, 1.9) \\
\hline
\end{tabular}




\begin{tabular}{|c|c|c|c|c|}
\hline $\begin{array}{l}\text { Author, Year } \\
\text { Country, N }\end{array}$ & Exposure & Outcome & Significant finding & NS finding \\
\hline & & $\begin{array}{l}\text { Preeclampsia } \\
\text { (OR) }\end{array}$ & & $\begin{array}{l}\text { Medium: } 0.7 \\
(95 \% \text { Cl: } 0.3,1.4)\end{array}$ \\
\hline & & Low=REF & & $\begin{array}{l}\text { High: } 1.1 \\
(95 \% \mathrm{Cl}: 0.6,2.1)\end{array}$ \\
\hline \multirow{12}{*}{$\begin{array}{l}\text { Schoenaker, } 2015 \\
\text { Australia } \\
N=3,582 \text { women } \\
\text { (6,149 } \\
\text { pregnancies) }\end{array}$} & Meat, high-fat, and sugar pattern & \multirow{3}{*}{\multicolumn{2}{|c|}{$\begin{array}{l}\text { Hypertensive } \\
\text { Disorders of } \\
\text { Pregnancy } \\
(\mathrm{RR})\end{array}$}} & Q2: 0.89 \\
\hline & Characterized by high consumption of & & & (95\% Cl: 0.64, 1.22) \\
\hline & $\begin{array}{l}\text { meat, processed meat, cakes, sweet } \\
\text { biscuits, chocolate, meat pies, and }\end{array}$ & & & $\begin{array}{l}\text { Q3: } 1.04 \\
\text { (95\% Cl: } 0.73,1.48)\end{array}$ \\
\hline & pizza & \multicolumn{2}{|l|}{ Q1=REF } & $\begin{array}{l}\text { Q4: } 0.94 \\
\text { (95\% Cl: } 0.57,1.55)\end{array}$ \\
\hline & Mediterranean-style pattern & \multirow{4}{*}{$\begin{array}{l}\text { Hypertensive } \\
\text { Disorders of } \\
\text { Pregnancy } \\
(\mathrm{RR}) \\
\text { Q1=REF }\end{array}$} & Q3: 0.70 & \multirow{4}{*}{$\begin{array}{l}\text { Q2: } 0.85 \\
(95 \% \mathrm{Cl}: 0.65,1.11)\end{array}$} \\
\hline & \multirow{3}{*}{$\begin{array}{l}\text { Characterized by high consumption of } \\
\text { vegetables, legumes, nuts, tofu, rice, } \\
\text { pasta, rye bread, red wine, and fish }\end{array}$} & & (95\% Cl: 0.50, 0.97) & \\
\hline & & & \multirow[t]{2}{*}{$\begin{array}{l}\text { Q4: } 0.58 \\
(95 \% \mathrm{Cl}: 0.42,0.81)\end{array}$} & \\
\hline & & & & \\
\hline & Fruit and low-fat dairy pattern & \multirow{3}{*}{\multicolumn{2}{|c|}{$\begin{array}{l}\text { Hypertensive } \\
\text { Disorders of } \\
\text { Pregnancy } \\
\text { (RR) }\end{array}$}} & Q2: 1.08 \\
\hline & \multirow{3}{*}{$\begin{array}{l}\text { Characterized by high consumption of } \\
\text { fruit, yogurt, low-fat cheese, and skim } \\
\text { milk }\end{array}$} & & & $(95 \% \mathrm{Cl}: 0.80,1.46)$ \\
\hline & & & & $\begin{array}{l}\text { Q3: } 0.98 \\
\text { (95\% Cl: } 0.70,1.37)\end{array}$ \\
\hline & & \multicolumn{2}{|l|}{ Q1=REF } & $\begin{array}{l}\text { Q4: } 0.97 \\
\text { (95\% Cl: } 0.71,1.32)\end{array}$ \\
\hline
\end{tabular}




\begin{tabular}{|c|c|c|c|c|}
\hline $\begin{array}{l}\text { Author, Year } \\
\text { Country, N }\end{array}$ & Exposure & Outcome & Significant finding & NS finding \\
\hline & \multirow{3}{*}{$\begin{array}{l}\text { Cooked vegetable pattern } \\
\text { Characterized by high consumption of } \\
\text { carrots, peas, cooked potatoes, } \\
\text { cauliflower, and pumpkin }\end{array}$} & \multirow{2}{*}{$\begin{array}{l}\text { Hypertensive } \\
\text { Disorders of } \\
\text { Pregnancy } \\
\text { (RR) }\end{array}$} & & $\begin{array}{l}\text { Q2: } 0.97 \\
\text { (95\% Cl: } 0.71,1.32)\end{array}$ \\
\hline & & & & $\begin{array}{l}\text { Q3: } 1.15 \\
(95 \% \text { Cl: } 0.86,1.54)\end{array}$ \\
\hline & & Q1=REF & & $\begin{array}{l}\text { Q4: } 1.04 \\
(95 \% \mathrm{Cl}: 0.73,1.48)\end{array}$ \\
\hline Utner ivietnoas & & & & \\
\hline
\end{tabular}




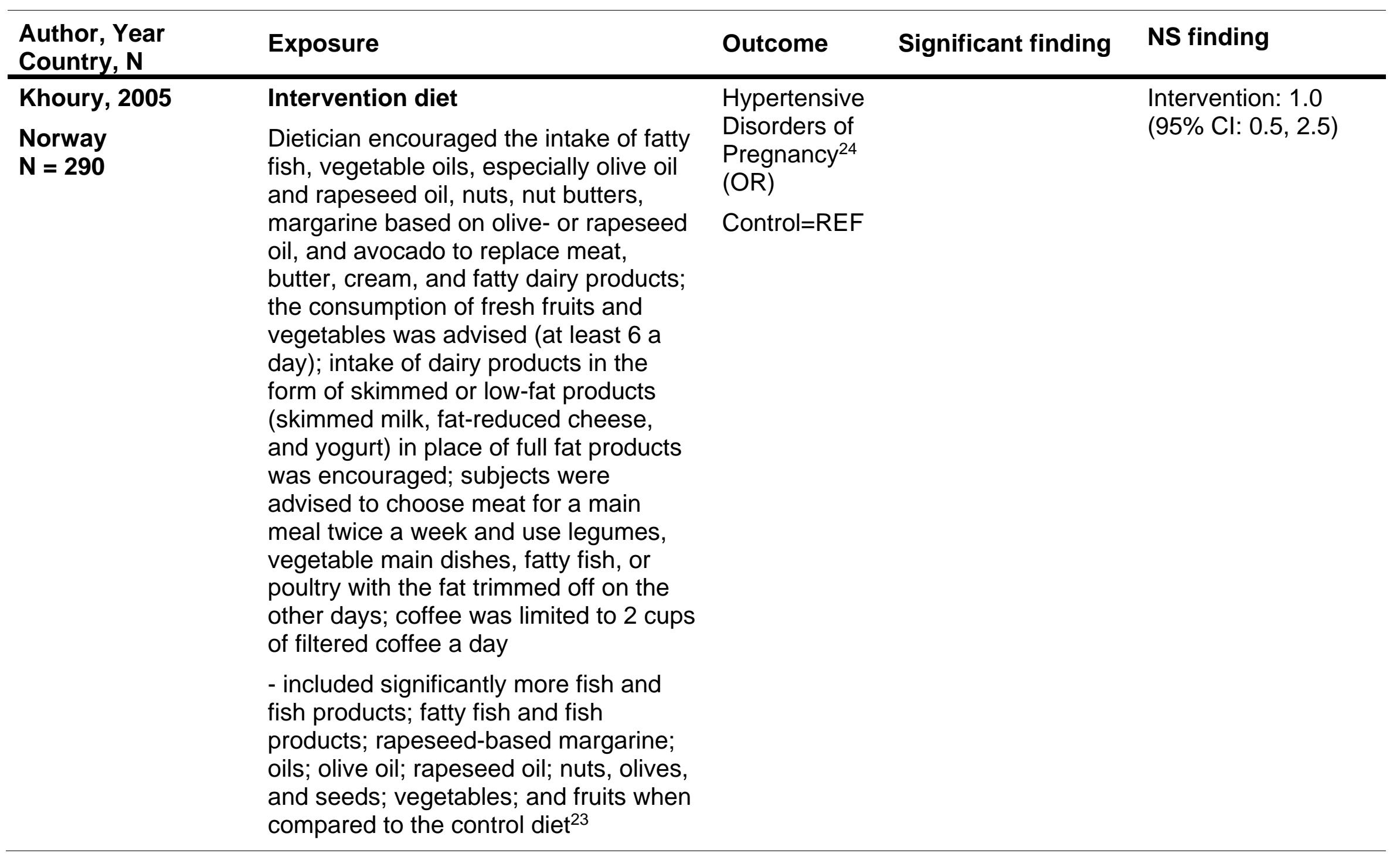

${ }^{23}$ Khoury, J., Henriksen, T., Seljeflot, I., Mørkrid, L., Frøslie, K. F., \& Tonstad, S. (2007). Effects of an antiatherogenic diet during pregnancy on markers of maternal and fetal endothelial activation and inflammation: the CARRDIP study. BJOG, 114(3), 279-288. doi:10.1111/j.1471-0528.2006.01187.x

${ }^{24}$ Addressed by the authors as "hypertensive complications" 


\begin{tabular}{|c|c|c|c|c|}
\hline $\begin{array}{l}\text { Author, Year } \\
\text { Country, N }\end{array}$ & Exposure & Outcome & Significant finding & NS finding \\
\hline & Control diet & & & \\
\hline
\end{tabular}




\section{Assessment of the body of evidence}

This body of evidence was deemed to be limited in strength. The individual grading elements are discussed below.

\section{Internal validity (determined with NEL Bias Assessment Tool):}

- The data were primarily observational in nature, making it difficult to determine causal effect of the dietary patterns.

- Dietary patterns were consistently assessed before collection of outcome data in all included studies. However, measurement of the time of exposure varied widely across studies and may have occurred years before pregnancy in the two studies from the ALSWH cohort.

- The use of self-reported exposure and outcome measurement might have introduced potential measurement error and could have limited the validity of these data.

- FFQ were the primary measurement tool, and both the self-reported data collected with this tool and the variability between studies in the type of FFQ used (i.e., number of items assessed, whether or not it is validated in a pregnant sample) could have affected the validity of the exposure data.

- As a result of methodological differences among studies, the dietary patterns studied varied considerably, which makes it difficult to compare findings across studies.

- The key confounders of parity, educational attainment, smoking status, race/ethnicity, maternal age, family poverty income ratio, pre-pregnancy BMI, mean total energy intake, and gestational diabetes mellitus were not consistently controlled across studies.

- Multiple studies did not report data on key confounding factors at baseline and did not control for potential differences across dietary groups in the analyses.

- Although data from a few more experimental studies or RCTs could strengthen these findings, it is not often practical and in some settings possibly unethical to use those study designs to answer the research question in this vulnerable population. Further, the limited time period for implementing an intervention during pregnancy is an additional constraint to use an experimental study design or RCT. Given all this, observational study designs are appropriate for studying dietary patterns, so these findings (primarily from observational studies) are not considered insufficient on this basis alone.

\section{Consistency:}

- There was some consistency across the body of evidence. Regardless of the method used to define them, healthier diets (defined different ways) were protective against the risk of HDP. Components of healthy patterns included high intakes of vegetables, fruits, grains (especially whole grains), nuts, legumes, fish, and vegetable oils and low intakes of meat and refined grain.

- Five out of eight studies observed a significant association between diet and the risk of HDP or blood pressure, while the single RCT and an observational study conducted in the U.S., each reported no association. One additional study found an association between DP and BP, but not with gestational hypertension or preeclampsia.

- Two of the dietary patterns assessed were found to be detrimental: a traditional 
pattern-with high intakes of meat and potatoes and low intakes of fruit, nonalcoholic drinks, fish, and bread-was associated with increased blood pressure, and a processed food pattern-with high intakes of processed meat products, white bread, French fries, salty snacks, and sugar-sweetened drinks and low intakes of oily fish, high-fiber breakfast cereals, and lean fish-was associated with increased risk of preeclampsia.

\section{Impact:}

- With two exceptions, the studies directly examined the relationship between different dietary patterns or different levels of adherence to a dietary pattern and HDP. The primary exposure of interest in Torjusen et al. 2014 was organic vegetable consumption. The purpose of CARRDIP trial was to test whether a cholesterol-lowering diet in pregnancy modified maternal, cord and neonatal cholesterol levels. Maternal and newborn complications were added as part of secondary analyses.

- The study based on the ALSWH cohort found that greater adherence to a Mediterranean-style diet during preconception period was inversely associated with the risk of developing HDP. The risk decreased by $30 \%$ and $42 \%$ for those women whose diets were in quartiles 3 and 4 , respectively.

- Among the three studies that found a significant association between dietary patterns and preeclampsia, effect sizes were more modest. Adherence to healthier dietary patterns was associated with $14-29 \%$ reductions in the risk of preeclampsia, while adherence to a processed foods dietary pattern increased the risk by $21 \%$.

- Nonetheless, together these findings suggest that there may be practical significance in encouraging women to consume a "healthy" diet (defined in several different ways in these studies) before and during pregnancy.

\section{Adequacy:}

- The number of studies and the number of unique research groups included in this evidence base was inadequate to answer the research question.

- This evidence base included eight studies corresponding to one RCT and four unique cohorts.

- As a result, there were also only five independent research groups contributing to this body of literature.

- The sample sizes varied considerably, ranging from 290 to 72,072 .

\section{Generalizability:}

- All but one of the studies were conducted outside the U.S.

- The study conducted in the U.S. was limited in generalizability to predominantly Caucasian women with access to health care.

- Minority and lower SES populations are underrepresented in these data. It is unknown if the findings would be comparable in more diverse samples before or during pregnancy.

- There was a lower prevalence of obesity in these samples compared to the U.S. national average.

- The largest sample considered here $(\mathrm{MoBa})$, which is used in three of the included studies, underrepresents young women, minorities, women with more 
than two children, women with previous stillbirths, smokers, and single mothers.

\section{Other limitations/considerations:}

- Different criteria were used across studies to define HDP, including self-report.

- Some studies included both gestational hypertension and preeclampsia as outcomes of interest, while others included only preeclampsia. Further, preeclampsia was sometimes defined as a combination of preeclampsia, eclampsia, and HELLP syndrome.

- Publication bias may be partly responsible for the wide array of dietary patterns in the literature. Journal editors and peer-reviewers may be less willing to publish studies that replicate others' findings. It is important for the editors and peer-reviewers to understand the need for publishing studies that replicate dietary patterns, in addition to publishing studies that assess unique dietary patterns.

\section{Research recommendations}

To assess the relationship between dietary patterns before and during pregnancy and risk of HDP more adequately, additional research is needed that should:

- Include diverse populations from the U.S. and elsewhere with varying racial/ethnic and socioeconomic backgrounds.

- Develop and validate novel epidemiological tools that can accurately capture the complexity of dietary habits.

- Improve comparability across studies by increasing the uniformity of 1) diet assessment tools used across different regions and populations, 2) methods used to define dietary patterns, and 3 ) timing of dietary assessment.

- Adjust for key confounding factors in observational studies, including parity, educational attainment, smoking status, race/ethnicity, maternal age, family poverty income ratio, pre-pregnancy BMI, mean total energy intake, fetal sex, and gestational diabetes mellitus (and/or justify how and why confounders were chosen).

- Include well-designed and sufficiently powered RCTs.

- Include and assess effect measure modification by fetal sex or multiethnic subgroups within the U.S.

- Use robust statistical methods such as multiple imputation to handle missing data. 


\section{Included articles}

1. Rifas-Shiman SL, Rich-Edwards JW, Kleinman KP, Oken E, Gillman MW. Dietary quality during pregnancy varies by maternal characteristics in Project Viva: a US cohort. J Am Diet Assoc 2009;109(6):1004-11.

2. Hillesund ER, Overby NC, Engel SM, Klungsoyr K, Harmon QE, Haugen M, Bere E. Associations of adherence to the New Nordic Diet with risk of preeclampsia and preterm delivery in the Norwegian Mother and Child Cohort Study (MoBa). Eur J Epidemiol 2014;29(10):753-65.

3. Schoenaker DA, Soedamah-Muthu SS, Mishra GD. Quantifying the mediating effect of body mass index on the relation between a Mediterranean diet and development of maternal pregnancy complications: the Australian Longitudinal Study on Women's Health. Am J Clin Nutr 2016;104(3):638-45.

4. Brantsaeter AL, Haugen M, Samuelsen SO, Torjusen H, Trogstad L, Alexander $\mathrm{J}$, Magnus $\mathrm{P}$, Meltzer HM. A dietary pattern characterized by high intake of vegetables, fruits, and vegetable oils is associated with reduced risk of preeclampsia in nulliparous pregnant Norwegian women. J Nutr 2009;139(6):1162-8.

5. Torjusen $\mathrm{H}$, Brantsaeter AL, Haugen M, Alexander J, Bakketeig LS, Lieblein G, Stigum H, Naes T, Swartz J, Holmboe-Ottesen G, et al. Reduced risk of preeclampsia with organic vegetable consumption: results from the prospective Norwegian Mother and Child Cohort Study. BMJ Open 2014;4(9):e006143.

6. Timmermans S, Steegers-Theunissen RP, Vujkovic M, Bakker R, den Breeijen $\mathrm{H}$, Raat $\mathrm{H}$, Russcher H, Lindemans J, Hofman A, Jaddoe VW, et al. Major dietary patterns and blood pressure patterns during pregnancy: the Generation R Study. Am J Obstet Gynecol 2011;205(4):337 e1-12.

7. Schoenaker DA, Soedamah-Muthu SS, Callaway LK, Mishra GD. Prepregnancy dietary patterns and risk of developing hypertensive disorders of pregnancy: results from the Australian Longitudinal Study on Women's Health. Am J Clin Nutr 2015;102(1):94-101.

8. Khoury J, Henriksen T, Christophersen B, Tonstad S. Effect of a cholesterollowering diet on maternal, cord, and neonatal lipids, and pregnancy outcome: a randomized clinical trial. Am J Obstet Gynecol 2005;193(4):1292-301. 


\section{ANALYTIC FRAMEWORK}

The analytic framework (Figure 1) illustrates the overall scope of the systematic review, including the population, the interventions and/or exposures, comparators, and outcomes of interest. It also includes definitions of key terms and identifies key confounders considered in the systematic review. This is the analytic framework for the systematic review conducted to examine the relationship between dietary patterns before and during pregnancy and risk of hypertensive disorders of pregnancy.

\section{Figure 1: Analytic framework}

Analytic Framework: What is the relationship between dietary patterns before and during pregnancy and risk of hypertensive disorders of pregnancy?

\section{Target Population}

Women preconception and during pregnancy (1st, 2nd and 3rd trimesters)

\section{Intervention/Exposure \\ Dietary pattern assessed using: \\ - Indices \& scores \\ - Factor \& cluster analysis \\ - Reduced rank regression \\ - Other methods \\ Comparator}

Different levels of adherence to a dietary pattern; Adherence to a different dietary pattern

\section{Intermediate Outcomes}

- Blood pressure (BP)

- Levels of protein in the urine (proteinuria)

\section{Endpoint Health Outcomes}

Hypertensive disorders of pregnancy

\section{Key Definitions}

- Dietary patterns: the quantities, proportions, variety or combinations of different foods and beverages in diets, and the frequency with which they are habitually consumed

- Hypertensive disorders of pregnancy: preeclampsia-eclampsia, chronic hypertension with superimposed preeclampsia, or gestational hypertension (hypertension is defined as either a systolic BP of $140 \mathrm{~mm} \mathrm{Hg}$ or greater, a diastolic $\mathrm{BP}$ of $90 \mathrm{~mm} \mathrm{Hg}$ or greater, or both; definition was adapted from the American College of Obstetricians and Gynecologists guideline)

\section{Key Confounders}

- Parity

- Educational attainment

- Smoking status

- Race/ethnicity

- Maternal age

- Family poverty income ratio

- Pre-pregnancy BMI

- Mean total energy intake

- Gestational diabetes 


\section{SEARCH PLAN AND RESULTS}

\section{Inclusion and exclusion criteria}

This table provides the inclusion and exclusion criteria for the systematic review question: what is the relationship between dietary patterns before and during pregnancy and gestational age- and sex-adjusted birth weight. The inclusion and exclusion criteria are a set of characteristics to determine which studies will be included or excluded in the systematic review.

Table 6. Inclusion and exclusion criteria

\begin{tabular}{|c|c|c|}
\hline Category & Inclusion Criteria & Exclusion Criteria \\
\hline $\begin{array}{l}\text { Study } \\
\text { Design }\end{array}$ & $\begin{array}{l}\text { - Randomized controlled trials } \\
\text { - Prospective cohort studies } \\
\text { - Retrospective cohort studies } \\
\text { - } \text { Nested case-control studies }\end{array}$ & $\begin{array}{l}\text { - } \text { Non-randomized controlled trials } \\
\text { - Cross-sectional studies } \\
\text { - Case-control studies } \\
\text { - Uncontrolled studies } \\
\text { - Pre/post studies with a control } \\
\text { - Pre/post studies without a } \\
\text { - } \text { control } \\
\text { - Syrrative reviews } \\
\text { - Meta-analyses }\end{array}$ \\
\hline $\begin{array}{l}\text { Exposure/ } \\
\text { Intervention }\end{array}$ & $\begin{array}{l}\text { - Studies that provide a } \\
\text { description of the dietary } \\
\text { pattern(s) (i.e., foods and } \\
\text { beverages) consumed by } \\
\text { subjects and that } \\
\text { methodologically use: } \\
\circ \text { Indices \& scores } \\
\circ \text { Cluster or factor analysis } \\
\circ \text { Reduced rank regression } \\
\circ \text { Other methods }\end{array}$ & $\begin{array}{l}\text { - Studies that do not provide a } \\
\text { description of the dietary } \\
\text { pattern(s) (i.e., foods and } \\
\text { beverages) consumed by } \\
\text { subjects }^{25}\end{array}$ \\
\hline
\end{tabular}

${ }^{25}$ For example, a study would be excluded from the systematic review if the dietary pattern were labeled "vegetarian" but lacked a description of what foods/beverages were consumed as part of that dietary pattern. 


\begin{tabular}{|c|c|c|}
\hline Category & Inclusion Criteria & Exclusion Criteria \\
\hline Comparator & $\begin{array}{l}\text { Different levels of adherence to } \\
\text { a dietary pattern } \\
\text { - Adherence to a different dietary } \\
\text { pattern }\end{array}$ & \\
\hline Date Range & $\begin{array}{l}\text { Studies published in the } \\
\text { following date range: 1980- } \\
\text { present (search date) }\end{array}$ & \\
\hline Language & - Studies published in English & $\begin{array}{l}\text { - Studies published in languages } \\
\text { other than English }\end{array}$ \\
\hline \multirow[t]{2}{*}{$\begin{array}{l}\text { Study } \\
\text { Setting }\end{array}$} & $\begin{array}{l}\text { - Studies conducted in Very High } \\
\text { and High Human Development } \\
\text { Countries }^{*}\end{array}$ & $\begin{array}{l}\text { - Studies conducted in Medium } \\
\text { and Low Human Development } \\
\text { Countries }^{*}\end{array}$ \\
\hline & $\begin{array}{l}{ }^{*} \text { Determined using the most recent } \\
\text { Human Development Index }\end{array}$ & $\begin{array}{l}{ }^{*} \text { Determined using the most recent } \\
\text { Human Development Index }\end{array}$ \\
\hline $\begin{array}{l}\text { Study } \\
\text { Duration }\end{array}$ & - Studies regardless of length & \\
\hline
\end{tabular}




\begin{tabular}{ll}
\hline Category & Inclusion Criteria \\
\hline Temporality & HDP \\
- & Studies when the exposure was \\
assessed prior to the outcome \\
- & Studies when exposure and \\
& outcome assessment occurred \\
& during overlapping time periods \\
& before the third trimester ( $<28$ \\
& weeks gestation) \\
Proteinuria & Studies when the exposure was \\
& assessed prior to the outcome \\
- & Studies when exposure and \\
outcome assessment occurred \\
during overlapping time periods \\
before the third trimester (<28 \\
weeks gestation) \\
Blood pressure
\end{tabular}

- Studies when the exposure was assessed prior to the outcome

\section{Exclusion Criteria}

$H D P$

- Studies when the outcome was assessed prior to the exposure

- Studies when exposure and outcome assessment occurred during overlapping time periods in the third trimester ( $\geq 28$ weeks gestation)

\section{Proteinuria}

- Studies when the outcome was assessed prior to the exposure

- Studies when exposure and outcome assessment occurred during overlapping time periods in the third trimester ( $\geq 28$ weeks gestation)

Blood pressure

- Studies when the outcome was assessed prior to the exposure

- Studies when exposure and outcome assessment occurred during overlapping time periods (irrespective of time period)

- Grey literature, including unpublished data, manuscripts, reports, abstracts, conference proceedings

\section{Study Subjects}

- Human subjects

- Adolescent girls and women capable of becoming pregnant (15-44 years)

- Pregnant girls and women (1544 years) - single and multiple pregnancies

- Neonates
- Animal and in vitro models

- Hospitalized patients, when hospitalization is not related to pregnancy, birth and immediate postpartum

- Pregnancies conceived ONLY using Assisted Reproductive Technologies

Size of Study - Studies regardless of group size Groups 


\begin{tabular}{|c|c|c|}
\hline Category & Inclusion Criteria & Exclusion Criteria \\
\hline $\begin{array}{l}\text { Health } \\
\text { Status of } \\
\text { Study } \\
\text { Subjects }\end{array}$ & $\begin{array}{l}\text { - Studies conducted in generally } \\
\text { healthy women of reproductive } \\
\text { age, including women in } \\
\text { pre/peri-conception and } \\
\text { pregnancy } \\
\text { - Studies conducted in samples } \\
\text { with elevated chronic disease } \\
\text { risk or pregnancy related } \\
\text { conditions, or that enroll some } \\
\text { subjects with a disease or with } \\
\text { health outcome of interest such } \\
\text { as } \\
\circ \text { Anemia } \\
\circ \text { Gestational diabetes } \\
\circ \text { Hypertension } \\
\circ \text { Preeclampsia } \\
\circ \text { Hypermesis Gravidarum } \\
\circ \text { Previous adverse } \\
\text { outcome (e.g., preterm) } \\
\circ \text { Obesity }\end{array}$ & $\begin{array}{l}\text { - Studies that exclusively enroll } \\
\text { subjects with chronic conditions } \\
\text { (e.g. hypertension, diabetes) } \\
\text { that are not related to the index } \\
\text { pregnancy } \\
\text { - } \quad \text { Studies that exclusively enroll } \\
\text { subjects with a disease or with } \\
\text { the health outcome of interest } \\
\text { (intermediate or endpoint health } \\
\text { outcomes) } \\
\text { - Studies done in hospitalized or } \\
\text { malnourished subjects, if } \\
\text { hospitalization is not related to } \\
\text { index pregnancy }\end{array}$ \\
\hline Outcomes & $\begin{array}{l}\text { - Hypertensive disorders of } \\
\text { pregnancy: 1) preeclampsia- } \\
\text { eclampsia, 2) preeclampsia } \\
\text { superimposed on chronic } \\
\text { hypertension, and 3) gestational } \\
\text { hypertension } \\
\text { - Intermediate Outcomes: } \\
\circ \text { Blood pressure } \\
\circ \text { Levels of protein in the } \\
\text { urine (proteinuria) }\end{array}$ & \\
\hline
\end{tabular}




\title{
Search terms and electronic databases used
}

\author{
PubMed, US National Library of Medicine
}

- Date(s) searched: January 1980 to January 2017

- Search Terms:

pregnancy[mh] OR "Prenatal Exposure Delayed Effects"[mesh] OR "Maternal Exposure"[mesh] OR "pregnant women"[mh] OR pregnan*[tiab] OR prenatal[tiab] OR maternal OR mother ${ }^{*}$ OR postpartum OR newborn* ${ }^{*}$ tiab] OR perinatal OR peri-natal OR pre-conception OR preconception OR periconception OR periconception OR "Infant, Newborn"[Mesh] OR neonat*[tiab] OR newly born* OR "Peripartum Period"[Mesh] OR peripartum[tiab] OR peripartum[tiab] OR gestation* OR natal OR puerperium[tiab] OR "Maternal Nutritional Physiological Phenomena"[Mesh]

\section{AND}

hypertensi*[tiab] OR "Hypertension"[Mesh:NoExp] OR vomit* OR diabetes*[tiab] OR diabetic*[tiab] OR "Birth Weight"[Mesh] OR "Birth Weight"[tiab] OR "Glucose Intolerance"[Mesh] OR Glucose Intoleran*[tiab] OR glucose toleran* OR "Insulin Resistance"[Mesh] OR Insulin Resistan*[tiab] OR Dysglycemia[tiab] OR fasting blood glucose* OR "Hemoglobin A, Glycosylated"[Mesh] OR "Proteinuria"[Mesh:noexp] OR Albuminuria OR "Blood Pressure"[mh] OR "blood pressure"[tiab]

OR

"Diabetes, Gestational"[Mesh] OR (gestation*[tiab] AND (diabetes*[tiab] OR diabetic*[tiab])) OR "Pre-Eclampsia"[Mesh] OR "Pre-Eclampsia"[tiab] OR preeclampsia[tiab] OR "Hypertension, Pregnancy-Induced"[Mesh] OR Eclampsia OR "Gestational Age"[Mesh] OR "Morning Sickness"[Mesh] OR (Hyperemesis Gravidarum) OR "Gestational Age"[tiab] OR "Obstetric Labor, Premature"[Mesh] OR ((prematur*[tiab] OR preterm [tiab]) AND (baby[tiab] OR infant*[tiab] OR birth OR labor OR membrane* OR babies)) OR "Fetal Growth Retardation"[Mesh] OR IUGR[tiab] OR "Intrauterine growth restriction" OR "Fetal Development"[Mesh:noexp] OR "Fetal Weight"[Mesh] OR "Umbilical Arteries"[Mesh] OR "Uterine Artery"[Mesh]

AND

("diet quality" OR dietary pattern* OR diet pattern* OR eating pattern* OR food pattern* OR eating habit* OR dietary habit* OR food habit* OR dietary profile* OR food profile* OR diet profile* OR eating profile* OR dietary guideline* OR dietary recommendation* OR eating style*) OR

(DASH[ti] OR DASH[tw] OR ("dietary approaches"[ti] AND hypertension[ti]) OR "Diet, Mediterranean"[Mesh] OR Mediterranean[ti] OR vegan* OR vegetarian* OR "Diet, Vegetarian"[Mesh] OR "prudent diet" OR "western diet" OR nordiet OR omni[ti] OR omniheart[tiab] OR (Optimal Macronutrient Intake Trial to Prevent Heart Disease) OR adventist* OR ((Okinawa* OR "Ethnic Groups"[Mesh] OR "plant based" OR Mediterranean[tiab] OR Nordic[tiab] OR "heart healthy"[tiab] OR indo-mediterranean) AND (diet[mh] OR diet[tiab] OR diets[tiab] OR 
food[mh]))) OR

("Guideline Adherence"[Mesh] AND (diet OR food OR eating OR eat OR dietary OR feeding OR nutrition OR nutrient*)) OR (adherence AND (nutrient* OR nutrition OR diet OR dietary OR food OR eat OR eating) AND (guideline* OR guidance OR recommendation $\left.{ }^{*}\right)$ ) OR

(dietary score* OR adequacy index* OR kidmed OR Diet Quality Index* OR Food Score* OR Diet Score* OR MedDietScore OR Dietary Pattern Score* OR "healthy eating index") OR

((index*[ti] OR score*[ti] OR indexes OR scoring[ti] OR indices[ti]) AND (dietary[ti] OR nutrient*[ti] OR eating[tiab] OR food[ti] OR food[mh] OR diet[ti] OR $\operatorname{diet}[\mathrm{mh}])$ AND (pattern* OR habit* OR profile*)) OR meals[mh] OR meals[tiab] OR meal[tiab] OR mealtime* ${ }^{*}$ tiab]

OR

$\operatorname{diet}[\mathrm{mh}: n o e x p]$ OR $\operatorname{diet}[\mathrm{ti}]$ OR $\operatorname{diets[ti]}$ OR food"[tiab] OR "Food"[mh:noexp] OR "Eating"[mh] OR dietary intake*[tiab] OR food intake*[tiab] OR food habits[mh] OR diet habit* $\left[\right.$ tiab] OR eating habit* ${ }^{*}$ tiab] OR food choice*[tiab] OR dietary choice*[tiab] OR dietary change*[tiab] NOT (editorial[ptyp] OR comment[ptyp] OR news[ptyp] OR letter[ptyp] OR review[ptyp] OR systematic[sb])

\section{Embase, Elsevier:}

- Date(s) searched: January 1980 to January 2017

- Search Terms:

'pregnancy'/exp OR 'pregnant woman'/exp OR 'prenatal period'/exp OR 'mother'/exp OR 'prenatal exposure'/exp OR 'prenatal growth'/exp OR 'puerperium'/exp OR 'newborn'/exp OR prematurity/exp OR pregnan*:ti,ab OR maternal:ti,ab OR mother*:ti,ab OR prenatal:ti,ab OR pre-natal:ti,ab OR 'puerperium':ti,ab OR postpartum:ti,ab OR newborn:ti,ab OR neonat*:ti,ab OR "newly born":ti,ab OR periconception:ti,ab OR peri-conception:ti,ab OR preconception:ti,ab OR preconception;ti,ab OR gestation* OR peripartum:ti,ab OR peri-partum:ti,ab OR natal:ti,ab OR gestation* OR 'perinatal development'/exp OR 'perinatal care'/de OR perinatal:ti,ab OR peri-natal:ti,ab OR 'puerperium'/de OR 'puerperium':ti,ab OR 'maternal nutrition'/exp

AND

hypertensi* ${ }^{\star}$ OR hyperemesis:ti,ab OR vomit*:ti,ab OR diabet* OR 'birth weight'/exp OR birthweight:ti,ab OR ((neonatal OR newborn) NEAR/3 weight)

OR

'glucose intolerance'/exp OR (Glucose NEAR/2 Intoleran*) OR (glucose NEAR/2 toleran*) OR 'insulin resistance'/exp OR (Insulin NEAR/1 Resistan*):ti,ab OR Dysglycemia OR "fasting blood glucose" OR 'hemoglobin A1c'/exp OR 'hemoglobin A1c' OR 'proteinuria'/exp OR albuminuria OR "Blood Pressure"/de OR

'pregnancy diabetes mellitus'/exp OR “diabetes mellitus gravidarum”:ti,ab OR 
'eclampsia OR preeclampsia'/exp OR eclampsia:ti,ab OR preeclampsia:ti,ab OR pre-eclampsia:ti,ab OR 'maternal hypertension'/exp OR 'gestational age'/exp OR 'small for date infant'/exp OR 'gestational age' OR 'hyperemesis gravidarum'/exp OR 'morning sickness'/exp OR (gestation* NEAR/2 diabet $^{\star}$ ):ti, ab OR (Obstetric NEAR/3 (Labor OR labour)) OR (labor/exp AND

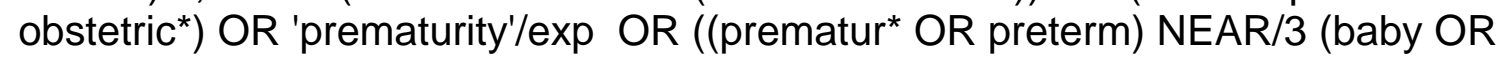
infant* OR babies OR birth OR childbirth OR labor OR membrane*)) OR 'intrauterine growth retardation'/de OR IUGR:ti,ab OR "Intrauterine growth restriction" OR 'fetus growth'/exp OR 'fetus development'/exp OR 'fetus weight'/exp OR 'umbilical artery'/exp OR 'uterine artery'/exp OR ((fetal OR fetus OR foetal OR foetus OR embryo*) NEAR/3 (weight OR develop* OR growth)):ti,ab

\section{AND}

'eating habit'/exp OR 'Mediterranean diet'/exp OR nordiet:ti,ab OR 'nordic diet':ti,ab OR DASH:ti,ab OR 'dietary approaches to stop hypertension':ti,ab OR vegan*:ab,ti OR vegetarian*:ab,ti OR 'vegetarian diet'/exp OR 'vegetarian'/exp OR 'prudent diet':ti,ab OR 'western diet':ti,ab OR 'Western diet'/exp OR meal/de OR omniheart:ti,ab OR omni:ti OR 'plant based diet' OR ((eating OR food OR diet $^{\star}$ OR calori ${ }^{\star}$ ) NEAR/3 (pattern? OR habit? OR profile? OR recommendation? OR guideline? OR style* OR choice* OR intake OR quality)) OR (('ethnic, racial and religious groups'/exp OR Okinawa* OR adventist* OR 'mediterranean') AND (diet/exp OR eating/exp OR 'food intake'/de OR calori* OR diet* OR food OR eating))

\section{OR}

Diet/de OR 'dietary intake'/de OR 'food preference'/de OR 'food intake'/de OR 'diet restriction'/exp OR 'eating habit'/exp OR diet*:ti OR kidmed:ab,ti OR 'meddietscore':ab,ti OR 'healthy eating index':ab,ti OR ((index OR score OR scoring OR indices) NEAR/3 (diet* OR eating OR food)) OR "food consumption"

OR

food $^{*}:$ ti,ab OR "Food"/de OR Eating:ti,ab OR (dietary NEAR/1 change*):ti,ab OR Meal*:ti,ab

\section{Cochrane, Central Register of Controlled Trials, John Wiley \& Sons:}

- Date(s) searched: January 1980 to January 2017

- Search Terms:

[mh pregnancy] OR [mh "Maternal Exposure"] OR [mh "Prenatal Exposure Delayed Effects"] OR [mh "pregnant women"] OR pregnan*:ti,ab OR prenatal OR maternal OR mother* OR postpartum OR newborn*:ti,ab OR perinatal OR perinatal OR pre-conception OR preconception OR peri-conception OR periconception OR [mh "Infant, Newborn"] OR neonat*:ti,ab OR (newly NEAR/1 born*) OR gestation* OR peripartum OR peri-partum OR natal:ti,ab OR puerperium OR gravidarum OR [mh "Peripartum Period"] OR peripartum:ti,ab 
OR peri-partum:ti,ab OR natal OR puerperium:ti,ab OR [mh "Maternal Nutritional Physiological Phenomena"]

AND

(hypertensi*:ti,ab OR [mh ^Hypertension] OR vomit* $:$ ti,ab OR diabet* ${ }^{\star}: t i, a b$ OR [mh "Birth Weight"] OR "Birth Weight":ti, ab OR [mh "Glucose Intolerance"] OR (Glucose NEAR/1 Intoleran*) OR (glucose NEAR/1 toleran*) OR [mh "Insulin Resistance"] OR (Insulin NEAR/1 Resistan*:ti,ab) OR Dysglycemia:ti,ab OR "fasting blood glucose" OR [mh "Hemoglobin A, Glycosylated"] OR [mh ^"Proteinuria"] OR Albuminuria OR [mh "Blood Pressure"] OR "blood pressure":ti,ab)

OR

[mh "Diabetes, Gestational"] OR (gestation* NEAR/1 diabet*) OR [mh "PreEclampsia"] OR "Pre-Eclampsia":ti,ab OR preeclampsia:ti,ab OR [mh "Hypertension, Pregnancy-Induced"] OR Eclampsia OR [mh "Gestational Age"] OR [mh "Morning Sickness"] OR (Hyperemesis NEAR/3 Gravidarum) OR "Gestational Age":ti,ab OR [mh "Birth Weight"] OR "Birth Weight":ti,ab OR ((neonatal OR newborn) NEAR/3 weight) OR [mh "Obstetric Labor, Premature"] OR ((prematur*:ti,ab OR preterm:ti,ab) AND (baby:ti,ab OR infant*:ti,ab OR birth OR labor OR membrane* OR babies)) OR [mh "Fetal Growth Retardation"] OR IUGR:ti,ab OR "Intrauterine growth restriction" OR [mh ^"Fetal Development"] OR [mh "Fetal Weight"] OR [mh "Umbilical Arteries"] OR [mh "Uterine Artery"]

AND (diet:ti OR diets:ti OR dietary:ti OR meal*:ti,ab OR "prudent diet" OR nordiet:ti,ab OR omniheart OR "Optimal Macronutrient Intake Trial to Prevent Heart Disease" OR ((Index OR score OR indices OR scoring) NEAR/3 (dietary OR diet OR food OR eating)) OR "adequacy index" OR kidmed OR MedDietScore)

OR 'dietary approaches to stop hypertension' :ti,ab OR omniheart:ti,ab OR omni:ti OR 'plant based diet' OR ((eating OR food OR diet* OR calori*) NEAR/3 (pattern? OR habit? OR profile? OR recommendation? OR guideline? OR style* OR choice* OR intake OR quality))

OR

food $^{*}:$ ti,ab OR Eating:ti,ab OR (dietary NEAR/1 change*):ti,ab OR DASH:ti,ab OR vegan*:ab,ti OR vegetarian*:ab,ti OR omni:ti OR ((ethni* OR racial OR religio* OR asia* OR western OR Okinawa* OR adventist* OR 'mediterranean' OR Nordic* OR indo-mediterranean) NEAR/3 (calori* OR diet $^{\star}$ OR food OR eating))

OR [mh "Diet, Mediterranean"] OR [mh "Diet, Vegetarian"] OR ([mh "Ethnic Groups"] AND ([mh diet] OR diet*:ti,ab OR [mh ^food] OR eat:ti,ab OR eating:ti,ab OR [mh "Eating"] OR [mh "food habits"])) OR

([mh "Guideline Adherence"] AND (diet OR food OR eating OR eat OR dietary)) OR ((adhere* OR adhering) AND (diet OR dietary OR food OR eat OR eating) AND (guideline* OR guidance OR recommendation $\left.{ }^{\star}\right)$ ) OR 
[mh meals] OR [mh ^diet] OR diet*:ti,ab OR [mh ^"Food"] OR [mh "Eating"] OR [mh "food habits"]

\section{CINAHL (Plus) with Full Text, EBSCO (Cumulative Index to Nursing and Allied Health Literature):}

- Date(s) searched: January 1980 to January 2017

- Search Terms:

(MH "Food and Beverages") OR (MH "Food") OR (MH "Diet") OR (MH "Eating") OR (MH "Eating Behavior") OR (MH "Meals+") OR (MH "Food Preferences") OR (MH "Food Habits") OR (MH "Mediterranean Diet") OR (MH "Diet, Western") OR (MH "DASH Diet") OR (MH "Vegetarianism")

OR meal* OR "prudent diet" OR nordiet OR omniheart OR "Optimal Macronutrient Intake Trial to Prevent Heart Disease" OR ((Index OR score OR indices OR scoring) N3 (dietary OR diet OR food OR eating)) OR "adequacy index" OR kidmed OR MedDietScore

OR "dietary approaches to stop hypertension" OR "plant based diet" OR ((eating OR food* OR diet* OR calori*) N3 (pattern? OR habit? OR profile? OR recommendation? OR guideline? OR style* OR choice ${ }^{\star}$ OR intake OR quality))

OR

(dietary NEAR/1 change*) OR vegan* OR vegetarian* OR ((ethni* OR racial OR religio* OR asia* OR western OR Okinawa* OR adventist ${ }^{\star}$ OR 'mediterranean' OR Nordic* OR indo-mediterranean OR omni ${ }^{\star}$ ) N3 (calori* OR diet $^{\star}$ OR food OR eating))

OR (MH "Ethnic Groups+") AND ((mh diet) OR diet* OR (MH food) OR eat OR eating OR (MH "Eating") OR MH "food habits")) OR

((adhere* OR adhering) N3 (diet OR dietary OR food OR eat OR eating)) AND (guideline ${ }^{\star}$ OR guidance OR recommendation $\left.{ }^{\star}\right)$ )

(MH "Maternal Nutritional Physiology+") OR (MH "Maternal Exposure") OR (MH "Pregnancy+") OR (MH "Pregnancy in Adolescence+") OR (MH "Maternal Age 14 and Under") OR (MH "Pregnancy Outcomes") OR (MH "Mothers+") OR (MH "Prenatal Nutritional Physiology") OR (MH "Infant, Newborn+") OR (MH "Postnatal Period+") OR (MH "Periconceptual Period")

AND

(MH "Hypertension+") OR (MH "Nausea and Vomiting+") OR (MH "Vomiting+") OR (MH "Birth Weight") OR (MH "Glucose Tolerance Test") OR (MH "Prediabetic State") OR (MH "Glucose Intolerance") OR (MH "Insulin Resistance+") OR (MH "Blood Pressure+") OR (MH "Proteinuria+") OR (MH "Hemoglobin A, Glycosylated")

OR

(MH "Diabetes Mellitus, Gestational") OR (MH "Gestational Age") OR (MH "PreEclampsia+") OR (MH "Eclampsia+") OR (MH "Fetal Growth Retardation") OR (MH "Fetal Weight") OR (MH "Umbilical Arteries") OR (MH "Delivery, 


\section{Obstetric+")}

Limiters - Published Date: 19800101-; Peer Reviewed; English Language;

Exclude MEDLINE records; Pregnancy

Narrow by SubjectMajor: - energy intake

Narrow by SubjectMajor: - vegetarianism

Narrow by SubjectMajor: - women's health

Narrow by SubjectMajor: - pregnancy outcomes

Narrow by SubjectMajor: - pregnancy complications

Narrow by SubjectMajor: - food habits

Narrow by SubjectMajor: - diabetes mellitus, gestational 
Figure 2: Flow chart of literature search and screening results

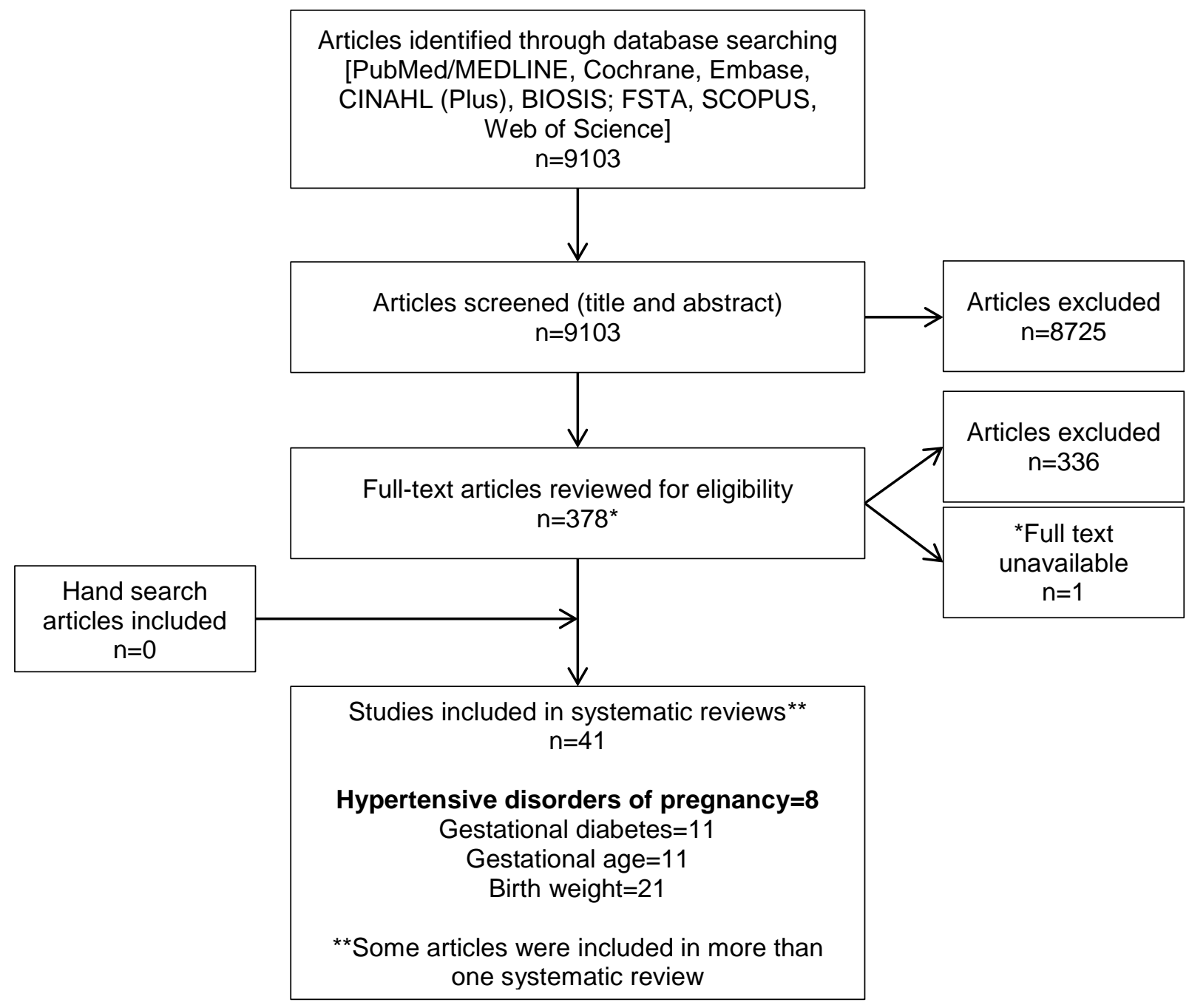

This flow chart illustrates the literature search and screening results for articles examining the relationship between dietary patterns before and during pregnancy and risk of hypertensive disorders of pregnancy. The results of the electronic database searches were screened independently by two NESR analysts in a step-wise manner by reviewing titles, abstracts, and full text articles to determine which articles met the criteria for inclusion. A manual search was done to ascertain articles not identified through the electronic database search. The systematic review on dietary patterns before and during pregnancy and risk of hypertensive disorders of pregnancy included 9103 articles. The literature search was conducted for multiple systematic reviews that addressed the relationships between dietary patterns before and during pregnancy and risk of hypertensive disorders of pregnancy, risk of gestational diabetes mellitus, gestational age, and gestational age- and sex-adjusted birth weight; the systematic reviews on gestational diabetes mellitus, gestational age, and gestational age- and sex-adjusted birth weight are reported elsewhere. 


\section{Excluded articles}

The table below lists the excluded articles with at least one reason for exclusion, and may not reflect all possible reasons.

\section{Table 7. Excluded articles}

\section{Citation}

1 Aaltonen, J, Ojala, T, Laitinen, K et al. Risk Reduction of Infant Insulin Resistance by Dietary Intervention during Pregnancy and Breastfeeding. Pediatric Academic Societies Annual Meeting; 2009 May 2 5; Baltimore MD, United States, 2009

2 Abel, Ht, Bannert, N, Starke, I et al. Study into Ca/P homeostasis in premature babies on different diets. Klin Padiatr, 1991, 203

3 Adami, G. F., Friedman, D., Cuneo, S. et al. Intravenous nutritional support in pregnancy. Experience following biliopancreatic diversion. Clinical Nutrition, 1992, 11: 106-109

$4 \quad$ Akbari, Z., Mansourian, M., Kelishadi, R. Relationship of the intake of different food groups by pregnant mothers with the birth weight and gestational age: Need for public and individual educational programs. J Educ Health Promot, 2015, 4. PMID:25883993.

5 Alfonso, H. Preventing preeclampsia: the evidence on nutrients. Nurs Womens Health, 2009, 13: 419-21. PMID:19821918.

$6 \quad$ Ali, H. I., Jarrar, A. H., El Sadig, M. et al. Diet and carbohydrate food knowledge of multiethnic women: a comparative analysis of pregnant women with and without Gestational Diabetes Mellitus. PLoS One, 2013, 8. PMID:24069200.

7 Alwan, N. A., Greenwood, D. C., Simpson, N. A. et al. Dietary iron intake during early pregnancy and birth outcomes in a cohort of British women. Hum Reprod, 2011, 26: 911-9. PMID:21303776.

8 Andreasyan, K., Ponsonby, A. L., Dwyer, T. et al. Higher maternal dietary protein intake in late pregnancy is associated with a lower infant ponderal index at birth. Eur J Clin Nutr, 2007, 61: 498-508. PMID:17136041.

9 Arkkola, T., Uusitalo, U., Kronberg-Kippila, C. et al. Seven distinct dietary patterns identified among pregnant Finnish women--associations with nutrient intake and sociodemographic factors. Public Health Nutr, 2008, 11: 176-82. PMID:17610760.

\section{Rationale}

Dependent variable

Independent variable

Independent variable

Independent variable Study design

Study design

Independent variable Independent variable Dependent variable 


\section{Citation}

\section{Rationale}

10 Asaka, A., Imaizumi, Y., Inouye, E. Analysis of multiple births in Japan. V. Effects of gestational age, maternal age and other factors on growth rate of weight in twins. Jinrui Idengaku Zasshi, 1981, 26: 83-90. PMID:7328851.

11 Asbee, Sm, Jenkins, Tr, Butler, Jr et al. Dietary counseling prevents excessive weight gain during pregnancy, a randomized controlled trial. Obstet Gynecol, 2008, 111

12 Asp, N. G. Nutrition and human development. Scandinavian Journal of Food and Nutrition, 2006, 50

design

13 Babson, Sg, Bramhall, Jl. Diet and growth in the premature infant. Journal of Pediatrics, 1969, Date 74: 890-900

14 Bakouei, S., Reisian, F., Lamyian, M. et al. High Intake of Manganese During Second Trimester, Increases the Risk of Preterm Delivery: A Large Scale Cohort Study. Glob J Health Sci, 2015, 7: 226-32. PMID:26156900.

15 Bao, W., Bowers, K., Tobias, D. K. et al. Prepregnancy low-carbohydrate dietary pattern and Independent variable risk of gestational diabetes mellitus: a prospective cohort study. Am J Clin Nutr, 2014, 99: 1378-84. PMID:24717341.

16 Bao, W., Li, S., Chavarro, J. E. et al. Low Carbohydrate-Diet Scores and Long-term Risk of Type 2 Diabetes Among Women With a History of Gestational Diabetes Mellitus: A Prospective Cohort Study. Diabetes Care, 2016, 39: 43-9. PMID:26577416.

17 Bao, W., Tobias, D. K., Hu, F. B. et al. Pre-pregnancy potato consumption and risk of gestational diabetes mellitus: prospective cohort study. Bmj, 2016, 352. PMID:26759275.

18 Bao, W., Tobias, D. K., Olsen, S. F. et al. Pre-pregnancy fried food consumption and the risk of gestational diabetes mellitus: a prospective cohort study. Diabetologia, 2014, 57: 2485-91. PMID:25303998.

19 Baron, R., Te Velde, S. J., Heymans, M. W. et al. The Relationships of Health Behaviour and Psychological Characteristics with Spontaneous Preterm Birth in Nulliparous Women. Matern Child Health J, 2016, . PMID:27581004.

20 Bell, E. H., Geyer, J., Jones, L. A structured intervention improves breastfeeding success for ill Dependent variable or preterm infants. MCN Am J Matern Child Nurs, 1995, 20: 309-14. PMID:8551932.

21 Berntorp, K. E. Gestational diabetes: what's up?. Diabetologia, 2016, 59: 1382-1384 Study design 


\section{Citation}

22 Bertolotto, A., Volpe, L., Calianno, A. et al. Physical activity and dietary habits during pregnancy: effects on glucose tolerance. J Matern Fetal Neonatal Med, 2010, 23: 1310-4. PMID:20334531.

23 Bhatia, B. D., Banerjee, D., Agarwal, D. K. et al. Fetal growth: relationship with maternal dietary intakes. Indian J Pediatr, 1983, 50: 113-20. PMID:6618569.

24 Bjerregaard, P., Hansen, J. C. Effects of smoking and marine diet on birthweight in Greenland. Independent variable Arctic Med Res, 1996, 55: 156-64. PMID:9115541.

25 Bloomfield, F. H., Oliver, M. H., Hawkins, P. et al. A periconceptional nutritional origin for noninfectious preterm birth. Science, 2003, 300. PMID:12714735.

26 Bo, S., Rosato, R., Ciccone, G. et al. Simple lifestyle recommendations and the outcomes of gestational diabetes. A 2 × 2 factorial randomized trial. Diabetes Obes Metab, 2014, 16: 1032 5. PMID:24646172.

27 Bobinski, R., Mikulska, M., Mojska, H. et al. Assessment of the diet components of pregnant women as predictors of risk of preterm birth and born baby with low birth weight. Ginekol Pol, 2015, 86: 292-9. PMID:26117989.

28 Bobinski, R., Mikulska, M., Mojska, H. et al. The Dietary Composition of Women Who Delivered Healthy Full-Term Infants, Preterm Infants, and Full-Term Infants Who Were Small for Gestational Age. Biol Res Nurs, 2015, 17: 495-502. PMID:25358685.

29 Borberg, C., Gillmer, M. D., Brunner, E. J. et al. Obesity in pregnancy: the effect of dietary advice. Diabetes Care, 1980, 3: 476-81. PMID:6993162.

30 Borgen, I., Aamodt, G., Harsem, N. et al. Maternal sugar consumption and risk of preeclampsia in nulliparous Norwegian women. Eur J Clin Nutr, 2012, 66: 920-5. PMID:22713766.

31 Bower, D. The influence of dietary salt intake on pre-eclampsia. Journal of obstetrics and gynaecology of the British Commonwealth, 1961, 63: 123-6

32 Bowers, K., Tobias, D. K., Yeung, E. et al. A prospective study of prepregnancy dietary fat intake and risk of gestational diabetes. Am J Clin Nutr, 2012, 95: 446-53. PMID:22218158.

\section{Rationale}

Independent

variable, study

design

Country

Independent variable, health status

Independent variable, health status

Independent variable, study design

\section{Independent} variable, study design

Independent variable

Independent variable

Date

Independent variable 


\section{Citation}

Rationale

33 Brantsaeter, A. L., Haugen, M., Myhre, R. et al. Diet matters, particularly in pregnancy â€“ Results from MoBa studies of maternal diet and pregnancy outcomes. Norsk Epidemiologi, 2014, 24: 63-77

34 Brantsaeter, A. L., Myhre, R., Haugen, M. et al. Intake of probiotic food and risk of preeclampsia in primiparous women: the Norwegian Mother and Child Cohort Study. Am J Epidemiol, 2011, 174: 807-15. PMID:21821542.

35 Breslow, S, Belafsky, Ha, Shangold, Je et al. Control of weight gain in pregnancy: double blind study of a dieting aid. Clinical medicine, 1963, 70: 931-8

36 Brooke, O. G. Low birth weight babies. Nutrition and feeding. Br J Hosp Med, 1982, 28: 462-9. Dependent variable PMID:7171896.

37 Brooke, O. G. Nutrition in the preterm infant. Lancet, 1983, 1: 514-6. PMID:6131220. Study subjects

38 Brown, J. E., Kahn, E. S., Hartman, T. J. Profet, profits, and proof: do nausea and vomiting of early pregnancy protect women from harmful vegetables?. Am J Obstet Gynecol, 1997, 176: 179-81. PMID:9024110.

39 Brumfield, C. G., Huddleston, J. F. The management of diabetic ketoacidosis in pregnancy. Independent variable Clin Obstet Gynecol, 1984, 27: 50-9. PMID:6423330.

40 Bruno, R., Petrella, E., Bertarini, V. et al. Adherence to a lifestyle programme in overweight/obese pregnant women and effect on gestational diabetes mellitus: a randomized controlled trial. Matern Child Nutr, 2016, . PMID:27647837.

Date

Buchanan, T. A., Kjos, S. L. Diabetes and pregnancy. Curr Ther Endocrinol Metab, 1994, 5: 278-83. PMID:7704732.

42 Buul, E, Rijpkema, A, Steegers, E et al. Chronic dietary sodium restriction in pregnancy reduces calcium intake. J Perinat Med, 1992, 20

43 Campbell, Dm. Dietary restriction in obesity and its effect on neonatal outcome. Nutrition in Pregnancy. Proceedings of 10th Study Group of the Rcog; 1983; London, UK, 1983, : 243-50

44 Canda, M. T., Sezer, O., Demir, N. An audit of seafood consumption awareness during pregnancy and its association with maternal and fetal outcomes in a Turkish population. J Obstet Gynaecol, 2011, 31: 293-7. PMID:21534748.

45 Carmichael, S. L., Yang, W., Shaw, G. M. Maternal dietary nutrient intake and risk of preterm delivery. Am J Perinatol, 2013, 30: 579-88. PMID:23208764.

Independent variable, study design

Study design

Independent variable

Not peer-reviewed

Independent variable

Independent variable, study design 


\section{Citation}

\section{Rationale}

46 Carter, J. P., Furman, T., Hutcheson, H. R. Preeclampsia and reproductive performance in a community of vegans. South Med J, 1987, 80: 692-7. PMID:3589760.

47 Carver, Jd, Saste, Md, Sosa, R et al. Dietary nucleotide (NT) effects on superior mesenteric artery (SMA) blood flow in preterm infants. Pediatr Res, 2000, 47

48 C'De Baca, J., Lapham, S. C., Skipper, B. J. et al. Use of computer interview data to test associations between risk factors and pregnancy outcomes. Comput Biomed Res, 1997, 30: 232-43. PMID:9281330.

49 Chamberlain, G. Epidemiology and aetiology of the preterm baby. Clin Obstet Gynaecol, 1984, Study design 11: 297-314. PMID:6478726.

50 Chandler-Laney, P. C., Schneider, C. R., Gower, B. A. et al. Association of late-night carbohydrate intake with glucose tolerance among pregnant African American women. Matern Child Nutr, 2016, 12: 688-98. PMID:25786515.

51 Chavarro, J. E., Halldorsson, T. I., Leth, T. et al. A prospective study of trans fat intake and Independent variable risk of preeclampsia in Denmark. Eur J Clin Nutr, 2011, 65: 944-51. PMID:21559043.

52 Chen, C. M., Weng, H. C., Li, Y. C. et al. The evaluation of dietary intervention on the blood glucose level of gestational diabetes mellitus pregnant women. Nutritional Sciences Journal, 1999, 24: 250-261

53 Chen, L., Hu, F. B., Yeung, E. et al. Prospective study of pre-gravid sugar-sweetened beverage consumption and the risk of gestational diabetes mellitus. Diabetes Care, 2009, 32: 2236-41. PMID:19940226.

54 Chong, M. F., Chia, A. R., Colega, M. et al. Maternal Protein Intake during Pregnancy Is Not Associated with Offspring Birth Weight in a Multiethnic Asian Population. J Nutr, 2015, 145: 1303-10. PMID:25948786.

55 Christian, K, Andreas, M, Martin, F. Diet and lifestyle modification in mothers with burnout syndrome: Ayurvedic versus conventional standard counselling-design of a randomised clinical pilot study (VEDA-Trial) [abstract]. European journal of integrative medicine [abstracts of the 5th european congress for integrative medicine; 2012 sept 21-22; flo, 2012, 4: 47-8

56 Clapp, J. F. Effects of Diet and Exercise on Insulin Resistance during Pregnancy. Metab Syndr Study design Relat Disord, 2006, 4: 84-90. PMID:18370754.

57 Clausen, T., Slott, M., Solvoll, K. et al. High intake of energy, sucrose, and polyunsaturated fatty acids is associated with increased risk of preeclampsia. Am J Obstet Gynecol, 2001, 185: 451-8. PMID:11518908. 


\section{Citation}

Rationale

58 Coelho Nde, L., Cunha, D. B., Esteves, A. P. et al. Dietary patterns in pregnancy and birth weight. Rev Saude Publica, 2015, 49. PMID:26398873.

59 Cooney, G. Food for thought. Midwives, 2008, 11: 30-1. PMID:24902215.

Study design

Study design

60 Cooper, M. L. Stories to learn from: toxemia in pregnancy. Midwifery Today Int Midwife, 2014, Not peer-reviewed : 18-21. PMID:25980103.

61 Corbett, M. A., Burst, H. V. Nutritional intervention in pregnancy. J Nurse Midwifery, 1983, 28: 23-9. PMID:6554311.

Study design, independent variable

62 Cosgrove, M., Davies, D. P. Poor diet in pregnancy may be a proxy for some other hostile influence on fetal growth [8]. Br Med J, 1996, 312: 1478-1479

Independent variable, study design

63 Costa-Orvay, Ja, Figueras-Aloy, J, Romera, G et al. The effects of varying protein and energy Independent variable intakes on the growth and body composition of very low birth weight infants. Nutr J, 2011, 10

64 Crozier, S. R., Inskip, H. M., Godfrey, K. M. et al. Nausea and vomiting in early pregnancy: Effects on food intake and diet quality. Matern Child Nutr, 2016, . PMID:27896913.

65 Dancause, K. N., Mutran, D., Elgbeili, G. et al. Dietary change mediates relationships between stress during pregnancy and infant head circumference measures: the QF2011 study. Matern Child Nutr, 2016, . PMID:27562643.

66 Darling, A. M., Mitchell, A. A., Werler, M. M. Preconceptional Iron Intake and Gestational Diabetes Mellitus. Int J Environ Res Public Health, 2016, 13. PMID:27231921.

67 Davidson, J. K. Newer approaches to diet management of diabetes: calorie control. Med Study design Times, 1980, 108: 35-40. PMID:7374404.

68 Davies, W. E., Hopkins, P. C., Rose, S. J. et al. The influence of different taurine diets on hearing development in normal babies. A preliminary report. Adv Exp Med Biol, 1996, 403: 631-7. PMID:8915404.

69 Davison, J. M., Lindheimer, M. D. Pregnancy in renal transplant recipients. J Reprod Med, 1982, 27: 613-21. PMID:6757420.

70 Dawn, Cs. Effects of substandard prenatal diet and nutrition on the development and incidence of pre-eclampsia of pregnancy. J Obstet Gynaecol India, 1961, 12: 237-45

71 de Seymour, J., Chia, A., Colega, M. et al. Maternal Dietary Patterns and Gestational Diabetes Mellitus in a Multi-Ethnic Asian Cohort: The GUSTO Study. Nutrients, 2016, 8. PMID:27657116. 


\section{Citation}

\section{Rationale}

72 Deka, D., Sharma, N. Nutrition in pregnancy and lactation. Perinatology, 2005, 7: 1-15

73 Delemarre, F. M., van Leest, L. A., Jongsma, H. W. et al. Effect of low-sodium diet on Independent variable uteroplacental circulation. J Matern Fetal Med, 2000, 9: 197-200. PMID:11048827.

74 Demmelmair, $\mathrm{H}$, Klingler, M, Campoy, $\mathrm{C}$ et al. The influence of habitual diet and increased docosahexaenoic acid intake during pregnancy on the fatty acid composition of individual placental lipids [Study design]. J Pediatr Gastroenterol Nutr, 2005, 40: 622-3

75 Deveer, R., Deveer, M., Akbaba, E. et al. The effect of diet on pregnancy outcomes among pregnant with abnormal glucose challenge test. Eur Rev Med Pharmacol Sci, 2013, 17: 125861. PMID:23690197.

76 Dieckmann, Wj, Davis, Me, Rynkiewicz, Lm et al. Does the administration of diethylstilbestrol Date during pregnancy have therapeutic value?. Am J Obstet Gynecol, 1953, 66: 1062-75

77 Diet \& nutrition. Good news: caffeine in pregnancy doesn't affect the baby's growth..and folic Not peer-reviewed acid seems to prevent cleft lip. Child Health Alert, 2007, 25: 5-6. PMID:17443983.

78 Dodd, J. M., Deussen, A. R., Mohamad, I. et al. The effect of antenatal lifestyle advice for women who are overweight or obese on secondary measures of neonatal body composition: The LIMIT randomised trial. BJOG: An International Journal of Obstetrics and Gynaecology, 2016, 123: 244-253

79 Dodd, J. M., McPhee, A. J., Turnbull, D. et al. The effects of antenatal dietary and lifestyle advice for women who are overweight or obese on neonatal health outcomes: the LIMIT randomised trial. BMC Med, 2014, 12. PMID:25315325.

80 Dominguez, L. J., Martinez-Gonzalez, M. A., Basterra-Gortari, F. J. et al. Fast food consumption and gestational diabetes incidence in the SUN project. PLoS One, 2014, 9. PMID:25215961.

81 Donnelly, J, Horan, M, Walsh, J et al. Impact of a Low Gl Diet on Neonatal Body Composition Not peer-reviewed [ROLO Kids]. Pediatric Academic Societies Annual Meeting, 2013,

82 Donnelly, J. M., Walsh, J. M., Byrne, J. et al. Impact of maternal diet on neonatal anthropometry: a randomized controlled trial. Pediatr Obes, 2015, 10: 52-6. PMID:24443392.

83 Doyle, W. Maternal nutrition and low birth weight. J Fam Health Care, 2002, 12. PMID:12630147.

84 Doyle, W., Crawford, M. A., Wynn, A. H. A. et al. Maternal nutrient intake and birth-weight. Journal of Human Nutrition and Dietetics, 1989, 2: 415-422 


\section{Citation}

\section{Rationale}

85 Drake, A. J., McPherson, R. C., Godfrey, K. M. et al. An unbalanced maternal diet in pregnancy associates with offspring epigenetic changes in genes controlling glucocorticoid action and foetal growth. Clin Endocrinol (Oxf), 2012, 77: 808-15. PMID:22642564.

86 Drouillet, P., Kaminski, M., De Lauzon-Guillain, B. et al. Association between maternal seafood consumption before pregnancy and fetal growth: evidence for an association in overweight women. The EDEN mother-child cohort. Paediatr Perinat Epidemiol, 2009, 23: 7686. PMID:19228317.

87 Dubois, S., Coulombe, C., Pencharz, P. et al. Ability of the Higgins Nutrition Intervention Program to improve adolescent pregnancy outcome. J Am Diet Assoc, 1997, 97: 871-8. PMID:9259709.

88 Dunn, C., Kolasa, K., Dunn, P. C. et al. Dietary intake of pregnant adolescents in a rural southern community. J Am Diet Assoc, 1994, 94: 1040-1. PMID:8071488.

Ebs, Jh, Tisdall, Ff, Scott, Wa. of Nutrition, 1941, 22: 515-26

90 Elmacioglu, F., Surucu, B., Alper, T. et al. Is adequate and balanced nutrition during pregnancy more effective than iron and folic acid supplements?. Central European Journal of Medicine, 2010, 5: 235-242

91 Ershoff, Dh, Aaronson, Nk, Danaher, Bg et al. Behavioral, health, and cost outcomes of an HMO based prenatal health education program. Public health reports, 1983, 98: 536-47

92 Ershoff, D. H., Aaronson, N. K., Danaher, B. G. et al.. Behavioral, health, and cost outcomes of an HMO-based prenatal health education program. Public Health Rep, 1983, 98: 536-47. PMID:6419268.

93 Eshriqui, I., Vilela, A. A., Rebelo, F. et al. Gestational dietary patterns are not associated with blood pressure changes during pregnancy and early postpartum in a Brazilian prospective cohort. Eur J Nutr, 2016, 55: 21-32. PMID:25526968.

94 Fairburn, C. G., Stein, A., Jones, R. Eating habits and eating disorders during pregnancy. Psychosom Med, 1992, 54: 665-72. PMID:1454960.

95 Farbu, J., Haugen, M., Meltzer, H. M. et al. Impact of singlehood during pregnancy on dietary intake and birth outcomes- a study in the Norwegian Mother and Child Cohort Study. BMC Pregnancy Childbirth, 2014, 14. PMID:25475509. 


\section{Citation}

Rationale

96 Fard, N Mehrabian F Sarraf-Zadegan NS. Fat-modified diets during pregnancy and lactation and serum lipids after birth. Indian J Pediatr, 2004, 71: 683-7

97 Farland, L. V., Rifas-Shiman, S. L., Gillman, M. W. Early Pregnancy Cravings, Dietary Intake, and Development of Abnormal Glucose Tolerance. J Acad Nutr Diet, 2015, 115. PMID:26099686.

98 Ferland, S., O'Brien, H. T. Maternal dietary intake and pregnancy outcome. J Reprod Med, 2003, 48: 86-94. PMID:12621791.

99 Flynn, A. C., Seed, P. T., Patel, N. et al. Dietary patterns in obese pregnant women; influence Health status of a behavioral intervention of diet and physical activity in the UPBEAT randomized controlled trial. Int J Behav Nutr Phys Act, 2016, 13. PMID:27894316.

100 Ford, J. H. Preconception risk factors and SGA babies: Papilloma virus, omega 3 and fat soluble vitamin deficiencies. Early Hum Dev, 2011, 87: 785-9. PMID:21705161.

101 Fowles, E. R., Gabrielson, M. First trimester predictors of diet and birth outcomes in lowincome pregnant women. J Community Health Nurs, 2005, 22: 117-30. PMID:15877540.

102 Fraser, R. B., Ford, F. A., Milner, R. D. G. A controlled trial of a high dietary fibre intake in pregnancy-effects in plasma glucose and insulin levels. Diabetologia, 1983, 25: 238-241

103 Fraser, Rb. High fibre diets in pregnancy. Nutrition in Pregnancy. Proceedings of 10th Study Group of the Royal College of Obstetricians and Gynaecologists; 1982 September, 1983, : 269-80

104 Garratt, F. N. Pre-eclampsia: a challenge to public health teams worldwide to ensure that maternal diets contain adequate levels of folic acid, n3 polyunsaturated fatty acids and vitamin D at conception. Public Health, 2009, 123: 95-6. PMID:19058819.

105 Gennaro, S., Biesecker, B., Fantasia, H. C. et al. Nutrition profiles of African [corrected] American women in the third trimester. MCN Am J Matern Child Nurs, 2011, 36: 120-6. PMID:21350375.

106 Gerrard, J., Popeski, D., Ebbeling, L. et al. Dietary omega 3 fatty acids and gestational hypertension in the Inuit. Arctic Med Res, 1991, : 763-7. PMID:1365294.

Study design, independent variable

Independent variable

Independent variable, study design

Independent variable Independent variable, not peer reviewed Study design Independent variable, dependent variable

Independent variable, study design 


\section{Citation}

Rationale

107 Gesteiro, E., Rodriguez Bernal, B., Bastida, S. et al. Maternal diets with low healthy eating index or Mediterranean diet adherence scores are associated with high cord-blood insulin levels and insulin resistance markers at birth. Eur J Clin Nutr, 2012, 66: 1008-15. PMID:22828732.

108 Ghebremeskel, K., Leighfield, M., Ashwell, M. et al. Infant brain lipids and diet [1]. Lancet, 1992, 340: 1093-1094

109 Gillen, L., Tapsell, L. C., Martin, G. S. et al. The type and frequency of consumption of carbohydrate-rich foods may play a role in the clinical expression of insulin resistance during pregnancy. Dietetics, 2002, 59: 135-143

110 Glueck, C. J., Goldenberg, N., Pranikoff, J. et al. Effects of metformin-diet intervention before Health status and throughout pregnancy on obstetric and neonatal outcomes in patients with polycystic ovary syndrome. Curr Med Res Opin, 2013, 29: 55-62. PMID:23205605.

111 Godfrey, K., Robinson, S., Barker, D. J. et al. Maternal nutrition in early and late pregnancy in Independent variable relation to placental and fetal growth. Bmj, 1996, 312: 410-4. PMID:8601112.

112 Grant, S. M., Wolever, T. M., O'Connor, D. L. et al. Effect of a low glycaemic index diet on blood glucose in women with gestational hyperglycaemia. Diabetes Res Clin Pract, 2011, 91: 15-22. PMID:21094553.

113 Gray-Donald, K., Robinson, E., Collier, A. et al. Intervening to reduce weight gain in pregnancy and gestational diabetes mellitus in Cree communities: an evaluation. Cmaj, 2000, 163: 1247-51. PMID:11107459.

114 Grivell, R. M., Yelland, L. N., Deussen, A. et al. Antenatal dietary and lifestyle advice for women who are overweight or obese and the effect on fetal growth and adiposity: the LIMIT randomised trial. Bjog, 2016, 123: 233-43. PMID:26841216.

115 Guilloty, N. I., Soto, R., Anzalota, L. et al. Diet, Pre-pregnancy BMI, and Gestational Weight Gain in Puerto Rican Women. Matern Child Health J, 2015, 19: 2453-61. PMID:26100133.

116 Guldner, L., Monfort, C., Rouget, F. et al. Maternal fish and shellfish intake and pregnancy outcomes: a prospective cohort study in Brittany, France. Environ Health, 2007, 6. PMID:17958907.

117 Gupta, A. P., Bhandari, B., Gupta, A. et al. Stool pH and sugar in preterm neonates. Indian J Independent variable Pediatr, 1984, 51: 391-3. PMID:6526446. 


\section{Citation}

\section{Rationale}

118 Haas, A. V. Diet du jour! Pregnancy and popular diets. Midwifery Today Int Midwife, 2014, : 53-5. PMID:25975083.

119 Haggarty, P., Campbell, D. M., Duthie, S. et al. Diet and deprivation in pregnancy. Br J Nutr, Independent variable 2009, 102: 1487-97. PMID:19682400.

120 Halldorsson, T. I., Thorsdottir, I., Meltzer, H. M. et al. Dioxin-like activity in plasma among Danish pregnant women: dietary predictors, birth weight and infant development. Environ Res, 2009, 109: 22-8. PMID:18945425.

121 Halldorsson, T. I., Thorsdottir, I., Meltzer, H. M. et al. Linking exposure to polychlorinated biphenyls with fatty fish consumption and reduced fetal growth among Danish pregnant women: a cause for concern?. Am J Epidemiol, 2008, 168: 958-65. PMID:18718897.

122 Hankin, Me, Symonds, Em. Body weight, diet and pre-eclamptic toxaemia of pregnancy. gynaecology, 1962, 4: 156-60

123 Harper, V., Maclnnes, R., Campbell, D. et al. Increased birth weight in northerly islands: is fish Independent variable consumption a red herring?. Bmj, 1991, 303. PMID:1878642.

124 Hatfield, Hm, Dunstan, Ja, Hayes, L et al. Dietary N-3 polyunsaturated fatty acid (PUFA) supplementation during pregnancy is associated with changes in cord blood (CB) progenitor numbers and responsiveness to IL-5 in infants at risk of atopy [Abstract]. Journal of allergy and clinical immunology, 2003, 111

125 Haugen, M., Brantsaeter, A. L., Trogstad, L. et al. Vitamin D supplementation and reduced risk of preeclampsia in nulliparous women. Epidemiology, 2009, 20: 720-6. PMID:19451820.

126 Hayashi, Tt, Phitaksphraiwan, P, Willson, Jr. Effects of diet and diuretic agents in pregnancy toxemias. Obstet Gynecol, 1963, 22: 327-34

127 Healthy diet halves the risk of diabetes after pregnancy. Kidney Care, 2013, 10: 6-6

Dependent variable

128 Hegsted, D. M. What is a healthful diet?. Prim Care, 1982, 9: 445-73. PMID:6924383. Dependent variable

129 Heim, T. Energy and lipid requirements of the fetus and the preterm infant. J Pediatr Gastroenterol Nutr, 1983, . PMID:6417303.

130 Hellmuth, C., Lindsay, K. L., Uhl, O. et al. Association of maternal prepregnancy BMI with metabolomic profile across gestation. Int J Obes (Lond), 2017, 41: 159-169. PMID:27569686. 


\section{Citation}

\section{Rationale}

131 Hennessy, M. D., Volpe, S. L., Sammel, M. D. et al. Skipping meals and less walking among

Independent variable African Americans diagnosed with preterm labor. J Nurs Scholarsh, 2010, 42: 147-55. PMID:20618599.

132 Heppe, D. H., Steegers, E. A., Timmermans, S. et al. Maternal fish consumption, fetal growth PMID:21266095.

133 Hernandez-Diaz, S., Boeke, C. E., Romans, A. T. et al. Triggers of spontaneous preterm delivery--why today?. Paediatr Perinat Epidemiol, 2014, 28: 79-87. PMID:24384058.

Independent variable delivery--why today?. Paediatr Perinat Epidemiol, 2014, 28:79-87. PMID:24384058.

134 Herrera, Mg, Mora, Jo, Paredes, B et al. Maternal weight/height and the effect of food supplementation during pregnancy and lactation. Maternal Nutrition during Pregnancy and Lactation. A Nestle Foundation Workshop; 1979 April 26-27; Lausanne Switzerland, 1980, : 252-63

135 Hoff, C., Wertelecki, W., Reyes, E. et al. Diet, blood pressure, and hematologic variables of nulliparous women attending a prenatal clinic. Obstet Gynecol, 1986, 67: 868-72. PMID:3703412.

136 Hoffman, D, Uauy, R, Birch, D et al. Essentiality of dietary docosahexaenoic acid (dha) for optimal visual maturation in preterm infants: plasma and red blood cell (rbc) fatty acid profiles. lovs, 1992, 33

137 Hoffman, Dr, Uauy, R. Essentiality of dietary n-3 fatty acids for premature infants; plasma and Independent variable red blood cell fatty acid composition. Lipids, 1992, 27: 886-95

138 Hollingsworth, D. R., Ney, D., Stubblefield, N. et al. Metabolic and therapeutic assessment of Dependent variable gestational diabetes by two-hour and twenty-four-hour isocaloric meal tolerance tests. Diabetes, 1985, : 81-7. PMID:3888746.

139 Hook, E. B. Influence of pregnancy on dietary selection. Int J Obes, 1980, 4: 338-40. PMID:7419353.

140 Horan, M. K., McGowan, C. A., Gibney, E. R. et al. Maternal low glycaemic index diet, fat intake and postprandial glucose influences neonatal adiposity--secondary analysis from the

Independent variable, study design

Independent variable, not peer reviewed

Independent variable

Dependent variable Study design Independent variable ROLO study. Nutr J, 2014, 13. PMID:25084967. 


\section{Citation}

141 Horan, M. K., McGowan, C. A., Gibney, E. R. et al. Maternal Nutrition and Glycaemic Index during Pregnancy Impacts on Offspring Adiposity at 6 Months of Age--Analysis from the ROLO Randomised Controlled Trial. Nutrients, 2016, 8. PMID:26742066.

142 Horan, M. K., McGowan, C. A., Gibney, E. R. et al. Maternal nutrition and glycaemic index during pregnancy impacts on offspring adiposity at 6 months of ageâ€"analysis from the ROLO randomised controlled trial. Nutrients, 2016, 8.

143 Huh, S. Y., Rifas-Shiman, S. L., Kleinman, K. P. et al. Maternal protein intake is not associated with infant blood pressure. Int J Epidemiol, 2005, 34: 378-84. PMID:15576466.

144 Hui, A. L., Ludwig, S. M., Gardiner, P. et al. Community-based exercise and dietary intervention during pregnancy: A pilot study. Canadian Journal of Diabetes, 2006, 30: 169-175

145 Hui, A., Back, L., Ludwig, S. et al. Lifestyle intervention on diet and exercise reduced excessive gestational weight gain in pregnant women under a randomized controlled trial. Obstetrical and Gynecological Survey, 2012, 67: 263-264

146 lyengar, L. Effects of dietary supplements late in pregnancy on the expectant mother and her newborn. Indian Journal of Medical Research, 1967, 55: 85-9

147 Jedrychowski, W., Perera, F., Mrozek-Budzyn, D. et al. Higher fish consumption in pregnancy may confer protection against the harmful effect of prenatal exposure to fine particulate matter. Ann Nutr Metab, 2010, 56: 119-26. PMID:20134157.

148 Jing, W., Huang, Y., Liu, X. et al. The effect of a personalized intervention on weight gain and physical activity among pregnant women in China. Int J Gynaecol Obstet, 2015, 129: 138-41. PMID:25697965.

149 Johnson, A. A., Knight, E. M., Edwards, C. H. et al. Dietary intakes, anthropometric measurements and pregnancy outcomes. J Nutr, 1994, 124. PMID:8201444.

150 Jovanovic-Peterson, L, Durak, Ep, Peterson, Cm. Randomized trial of diet vs diet plus cardiovascular conditioning on glucose levels in gestational diabetes. Am J Obstet Gynecol, 1989, 161: 415-9

151 Jovanovic-Peterson, L., Peterson, C. M. Turning point in the management of pregnancies complicated by diabetes. Normoglycemia with self blood glucose monitoring of diet and insulin dosing. ASAIO Trans, 1990, 36: 799-804. PMID:2268482.

152 Jowett, N. I., Nichol, S. G. Diabetic pregnancy. Midwives Chron, 1987, 100: 33-6. PMID:3645266.

\section{Rationale}

Independent variable, dependent variable

Duplicate

Independent variable

Independent variable

Independent variable

Date

Independent variable

Independent variable Independent variable

Health status Independent variable, study design

Study design 


\section{Citation}

\section{Rationale}

153 Kafatos, A. G., Vlachonikolis, I. G., Codrington, C. A. Nutrition during pregnancy: the effects of Independent variable an educational intervention program in Greece. Am J Clin Nutr, 1989, 50: 970-9.

PMID:2816804.

154 Kalhan, S. C., Tserng, K. Y., Gilfillan, C. et al. Metabolism of urea and glucose in normal and diabetic pregnancy. Metabolism, 1982, 31: 824-33. PMID:7098852.

155 Kaseb, F., Kimiagar, M., Ghafarpoor, M. et al. Effect of traditional food supplementation during pregnancy on maternal weight gain and birthweight. Int J Vitam Nutr Res, 2002, 72: 389-93. PMID:12596505.

156 Kelleher, C. C., Viljoen, K., Khalil, H. et al. Longitudinal follow-up of the relationship between Study design dietary intake and growth and development in the Lifeways cross-generation cohort study 2001-2013. Proc Nutr Soc, 2014, 73: 118-31. PMID:24300176.

157 Kesmodel, U., Olsen, S. F., Salvig, J. D. Marine n-3 fatty acid and calcium intake in relation to pregnancy induced hypertension, intrauterine growth retardation, and preterm delivery. A case-control study. Acta Obstet Gynecol Scand, 1997, 76: 38-44. PMID:9033242.

158 Khoury, J, Haugen, G, Tonstad, S et al. Effect of an antiatherogenic diet on maternal and fetal Not peer-reviewed Doppler velocimetry: a randomized clinical trial. 35th Nordic Congress of Obstetrics and Gynecology; 2006 May 23-25; Goteburg, Sweden, 2008,

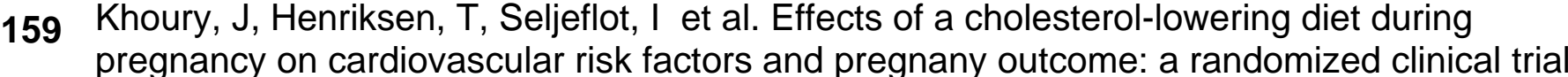
[Study design]. Atherosclerosis. Supplements, 2006, 7

160 Khoury, J., Haugen, G., Tonstad, S. et al. Effect of a cholesterol-lowering diet during pregnancy on maternal and fetal Doppler velocimetry: the CARRDIP study. Am J Obstet Gynecol, 2007, 196. PMID:17547890.

161 Kinnunen, T. I., Pasanen, M., Aittasalo, M. et al. Preventing excessive weight gain during pregnancy - a controlled trial in primary health care. Eur J Clin Nutr, 2007, 61: 884-91. PMID:17228348.

162 Kinnunen, T. I., Puhkala, J., Raitanen, J. et al. Effects of dietary counselling on food habits and dietary intake of Finnish pregnant women at increased risk for gestational diabetes - a secondary analysis of a cluster-randomized controlled trial. Matern Child Nutr, 2014, 10: 18497. PMID:22735030.

Study design

Independent variable

Independent variable

Independent variable, dependent variable 


\section{Citation}

Rationale

163 Kizirian, N. V., Kong, Y., Muirhead, R. et al. Effects of a low-glycemic index diet during pregnancy on offspring growth, body composition, and vascular health: a pilot randomized controlled trial. Am J Clin Nutr, 2016, 103: 1073-82. PMID:26936333.

164 Klebanoff, M. A., Harper, M., Lai, Y. et al. Fish consumption, erythrocyte fatty acids, and preterm birth. Obstet Gynecol, 2011, 117: 1071-7. PMID:21508745.

165 Knudsen, V. K., Heitmann, B. L., Halldorsson, T. I. et al. Maternal dietary glycaemic load during pregnancy and gestational weight gain, birth weight and postpartum weight retention: a study within the Danish National Birth Cohort. Br J Nutr, 2013, 109: 1471-8. PMID:22906835.

166 Knuist, M., Bonsel, G. J., Zondervan, H. A. et al. Low sodium diet and pregnancy-induced hypertension: a multi-centre randomised controlled trial. Br J Obstet Gynaecol, 1998, 105: 430-4. PMID:9609271.

167 Koivusalo, S. B., Rono, K., Klemetti, M. M. et al. Gestational Diabetes Mellitus Can Be Prevented by Lifestyle Intervention: The Finnish Gestational Diabetes Prevention Study (RADIEL): A Randomized Controlled Trial. Diabetes Care, 2016, 39: 24-30. PMID:26223239.

168 Kokanali, M. K., Tokmak, A., Kaymak, O. et al. The effect of treatment on pregnancy outcomes in women with one elevated oral glucose tolerance test value. Ginekol Pol, 2014, 85: 748-53. PMID:25546925.

169 Kolu, P., Raitanen, J., Rissanen, P. et al. Cost-effectiveness of lifestyle counselling as primary Independent variable prevention of gestational diabetes mellitus: findings from a cluster-randomised trial. PLoS One, 2013, 8. PMID:23457562.

170 Korpi-Hyovalti, E., Schwab, U., Laaksonen, D. E. et al. Effect of intensive counselling on the quality of dietary fats in pregnant women at high risk of gestational diabetes mellitus. Br J Nutr, 2012, 108: 910-7. PMID:22093485.

171 Kubota, K., Itoh, H., Tasaka, M. et al. Changes of maternal dietary intake, bodyweight and fetal growth throughout pregnancy in pregnant Japanese women. J Obstet Gynaecol Res, 2013, 39: 1383-90. PMID:23815608.

172 Kumar, P., Nangia, S., Saili, A. et al. Growth and morbidity patterns of exclusively breast-fed preterm babies. Indian Pediatr, 1999, 36: 296-300. PMID:10713842.

173 Lakin, V., Haggarty, P., Abramovich, D. R. et al. Dietary intake and tissue concentration of fatty acids in omnivore, vegetarian and diabetic pregnancy. Prostaglandins Leukot Essent Fatty Acids, 1998, 59: 209-20. PMID:9844995. 


\section{Citation}

\section{Rationale}

174 Langley-Evans, A. J., Langley-Evans, S. C. Relationship between maternal nutrient intakes in early and late pregnancy and infants weight and proportions at birth: prospective cohort study. J R Soc Promot Health, 2003, 123: 210-6. PMID:14669495.

175 Laraia, B. A., Siega-Riz, A. M., Kaufman, J. S. et al. Proximity of supermarkets is positively associated with diet quality index for pregnancy. Prev Med, 2004, 39: 869-75. PMID:15475018.

176 Latva-Pukkila, U., Isolauri, E., Laitinen, K. Dietary and clinical impacts of nausea and vomiting during pregnancy. J Hum Nutr Diet, 2010, 23: 69-77. PMID:19943842.

177 Leblance, H., Passa, P. Diabetes and pregnancy. Revue du Praticien - Medecine Generale, 1992, 6: 577-582

Lechtig, A, Habicht, Jp, Delgado, $\mathrm{H}$ et al. Effect of food supplementation during pregnancy on birthweight. Pediatrics, 1975, 56: 508-20

179 Lenders, C. M., Hediger, M. L., Scholl, T. O. et al. Gestational age and infant size at birth are associated with dietary sugar intake among pregnant adolescents. J Nutr, 1997, 127: 1113-7. PMID:9187625.

180 Ley, S. H., Hanley, A. J., Retnakaran, R. et al. Effect of macronutrient intake during the second trimester on glucose metabolism later in pregnancy. Am J Clin Nutr, 2011, 94: 123240. PMID:21955650.

Dependent variable L'Heureux, J. Got sugar? Tips on preventing diabetes. Posit Living, 2002, 11: 12-4. PMID:12083048.

182 Li, S., Zhu, Y., Chavarro, J. E. et al. Healthful Dietary Patterns and the Risk of Hypertension Among Women With a History of Gestational Diabetes Mellitus: A Prospective Cohort Study. Hypertension, 2016, 67: 1157-65. PMID:27091899.

183 Lilja, G, Dannaeus, A, Foucard, T et al. Effects of maternal diet during late pregnancy and lactation on the development of atopic disease in infants up to 18 months of age - in-vivo results. Clinical and Experimental Allergy, 1989, 19: 473-9

184 Liu, X., Lv, L., Zhang, H. et al. Folic acid supplementation, dietary folate intake and risk of preterm birth in China. European Journal of Nutrition, 2016, 55: 1411-1422

Dependent variable

Study design, language

Date

Independent variable (1)

185 Lorber, D. Gestational diabetes: The hidden epidemic. Female Patient - Practical Ob/Gyn Medicine, 1990, 15: 15-25 


\section{Citation}

\section{Rationale}

186 Luoto, R, Nermes, M, Laitinen, K et al. Impact of Maternal Probiotic-Supplemented Dietary Counselling on Pregnancy Outcome and Prenatal and Postnatal Growth: A Double-Blind, Placebo-Controlled Study. Pediatric Academic Societies Annual Meeting; 2009 May 2 5; Baltimore MD, United States, 2009,

187 MacGillivray, I. Aetiology of pre-eclampsia. Br J Hosp Med, 1981, 26. PMID:7296126.

Independent variable, study design

188 MacNeill, S., Dodds, L., Hamilton, D. C. et al. Rates and risk factors for recurrence of gestational diabetes. Diabetes Care, 2001, 24: 659-62. PMID:11315827.

189 Mahony, R, Byrne, J, Curran, S et al. A pilot study of the feasibility of a randomised trial of low glycaemic diet versus normal diet from early pregnancy in euglycaemic women. Arch Dis Child Fetal Neonatal Ed, 2008, 93

190 Makela, J., Lagstrom, H., Kaljonen, A. et al. Hyperglycemia and lower diet quality in pregnant overweight women and increased infant size at birth and at 13 months of age--STEPS study. Early Hum Dev, 2013, 89: 439-44. PMID:23375946.

191 Maresh, M, Alderson, C, Beard, Rw et al. Comparison of insulin against diet treatment in the management of abnormal carbohydrate tolerance in pregnancy. Nutrition in Pregnancy. Proceedings of 10th Study Group of the Rcog; 1983, 1983, : 255-67

Independent variable

Not peer-reviewed

Study design Independent variable, not peer reviewed

192 Mariscal-Arcas, M., Rivas, A., Monteagudo, C. et al. Proposal of a Mediterranean diet index for pregnant women. Br J Nutr, 2009, 102: 744-9. PMID:19243664.

193 Markovic, T. P., Muirhead, R., Overs, S. et al. Randomized Controlled Trial Investigating the Effects of a Low-Glycemic Index Diet on Pregnancy Outcomes in Women at High Risk of Gestational Diabetes Mellitus: The GI Baby 3 Study. Diabetes Care, 2016, 39: 31-8. PMID:26185283.

194 Marshall, J. Infant feeding: 8. Breastfeeding premature babies. Pract Midwife, 2013, 16. PMID:23789255.

195 Martin, C. L., Siega-Riz, A. M., Sotres-Alvarez, D. et al. Maternal Dietary Patterns are Associated with Lower Levels of Cardiometabolic Markers during Pregnancy. Paediatr Perinat Epidemiol, 2016, 30: 246-55. PMID:26848932.

196 Maten, Gd, Hammen, Rm, Visman, $L$ et al. Effects of a sodium restricted diet during pregnancy on maternal blood pressure and zinc status. J Perinat Med, 1992, 20
Dependent variable

Independent variable Dependent variable Study design

Independent variable 


\section{Citation}

\section{Rationale}

197 Mathews, F., Yudkin, P., Neil, A. Influence of maternal nutrition on outcome of pregnancy: prospective cohort study. Bmj, 1999, 319: 339-43. PMID:10435950.

198 Mathewson, M. Women diagnosed with pregnancy-induced hypertension (pre-eclampsia) should be placed on sodium restricted diets. Crit Care Nurse, 1983, 3. PMID:6552952.

199 McFadyen, A. Intervention in mothers with eating disorders and their babies (controlled trial). National Research Register, 2000,

200 McGowan, C. A., Walsh, J. M., Byrne, J. et al. The influence of a low glycemic index dietary intervention on maternal dietary intake, glycemic index and gestational weight gain during pregnancy: a randomized controlled trial. Nutr J, 2013, 12. PMID:24175958.

201 McGuire, Mk, Burgert, SI, Milner, Ja et al. Selenium status of infants is influenced by supplementation of formula or maternal diets. American Journal of Clinical Nutrition, 1993, 58: 643-8

202 Meinila, J., Koivusalo, S. B., Valkama, A. et al. Nutrient intake of pregnant women at high risk Dependent variable of gestational diabetes. Food Nutr Res, 2015, 59. PMID:25994096.

203 Meinila, J., Valkama, A., Koivusalo, S. B. et al. Healthy Food Intake Index (HFII) - Validity and Dependent variable reproducibility in a gestational-diabetes-risk population. BMC Public Health, 2016, 16. PMID:27475905.

204 Meltzer, H. M., Brantsaeter, A. L., Nilsen, R. M. et al. Effect of dietary factors in pregnancy on Study design risk of pregnancy complications: results from the Norwegian Mother and Child Cohort Study. Am J Clin Nutr, 2011, 94. PMID:21543541.

205 Mendelson, R., Dollard, D., Hall, P. et al. The impact of the Healthiest Babies Possible Program on maternal diet and pregnancy outcome in underweight and overweight clients. J Can Diet Assoc, 1991, 52: 229-34. PMID:10116012.

206 Mendez, M. A., Plana, E., Guxens, M. et al. Seafood consumption in pregnancy and infant size at birth: results from a prospective Spanish cohort. J Epidemiol Community Health, 2010, 64: 216-22. PMID:19710045.

207 Mestman, J. H. Outcome of diabetes screening in pregnancy and perinatal morbidity in infants Independent variable of mothers with mild impairment in glucose tolerance. Diabetes Care, 1980, 3: 447-52. PMID:7389561.

208 Mikkelsen, T. B., Osler, M., Orozova-Bekkevold, I. et al. Association between fruit and Independent variable vegetable consumption and birth weight: a prospective study among 43,585 Danish women. Scand J Public Health, 2006, 34: 616-22. PMID:17132595. 


\section{Citation}

\section{Rationale}

209 Mikode, M. S., White, A. A. Dietary assessment of middle-income pregnant women during the

Independent variable first, second, and third trimesters. J Am Diet Assoc, 1994, 94: 196-9. PMID:8300999.

210 Misra, A., Ray, S., Patrikar, S. A longitudinal study to determine association of various maternal factors with neonatal birth weight at a tertiary care hospital. Med $\mathrm{J}$ Armed Forces India, 2015, 71: 270-3. PMID:26288495.

211 Mitchell, J., Mackerras, D. The traditional humoral food habits of pregnant VietnameseAustralian women and their effect on birth weight. Aust J Public Health, 1995, 19: 629-33. PMID:8616205.

212 Mohanty, A. F., Thompson, M. L., Burbacher, T. M. et al. Periconceptional Seafood Intake and Fetal Growth. Paediatr Perinat Epidemiol, 2015, 29: 376-87. PMID:26147526.

213 Moldenhauer, J, Guo, S, Liang, R et al. Dietary intake levels of the antioxidants vitamin $\mathrm{c}$ and vitamin e are adequately achieved with standard prenatal vitamin supplementation in high risk pregnancy groups [abstract]. Am J Obstet Gynecol, 2002, 187

214 Moore, V. M., Davies, M. J., Willson, K. J. et al. Dietary composition of pregnant women is related to size of the baby at birth. J Nutr, 2004, 134: 1820-6. PMID:15226475.

215 Morley, R, Lucas, A. Randomised diet in the neonatal period and growth performance until 7.5-8 y of age in preterm children. American Journal of Clinical Nutrition, 2000, 71: 822-8

216 Morley, R., Lucas, A. Early diet and outcome in prematurely born. Clinical Nutrition, 1993, 12: 6-11

\section{Country}

Independent variable

Independent variable

Not peer-reviewed

Independent variable

Dependent variable

217 Morrison, Ra, Brien, Pms, Micklewright, A. The effect of dietary supplementation with linoleic acid on the development of pregnancy induced hypertension. 4th World Congress of the International Society for the Study of Hypertension in Pregnancy;1984 June 18-21;

Amsterdam, the Neth, 1984,

218 Morrison, Ra, Brien, Pms. The effect of dietary supplementation with prostaglandin precursors Not peer-reviewed in pregnancy induced hypertension $(\mathrm{PIH})$. 5th International Congress of the International Society for the Study of Hypertension in Pregnancy; 1986 7-10 July, Nottingham,, 1986,

219 Morton, N. E., Gulbrandsen, C. L., Rao, D. C. et al. Determinants of blood pressure in Japanese-American Families. Hum Genet, 1980, 53: 261-6. PMID:7358393. 


\section{Citation}

\section{Rationale}

220 Moses, R. G., Casey, S. A., Quinn, E. G. et al. Pregnancy and Glycemic Index Outcomes study: effects of low glycemic index compared with conventional dietary advice on selected pregnancy outcomes. Am J Clin Nutr, 2014, 99: 517-23. PMID:24351875.

221 Moses, R. G., Luebcke, M., Davis, W. S. et al. Effect of a low-glycemic-index diet during pregnancy on obstetric outcomes. Am J Clin Nutr, 2006, 84: 807-12. PMID:17023707.

222 Moses, R. G., Luebke, M., Petocz, P. et al. Maternal diet and infant size 2 y after the completion of a study of a low-glycemic-index diet in pregnancy [5]. American Journal of Clinical Nutrition, 2007, 86

223 Moses, Rg, Luebke, M, Petocz, $\mathrm{P}$ et al. Maternal diet and infant size 2 y after the completion of a study of a low-glycemic-index diet in pregnancy. American Journal of Clinical Nutrition, 2007, 86

224 Moss, J. L., Harris, K. M. Impact of maternal and paternal preconception health on birth outcomes using prospective couples' data in Add Health. Arch Gynecol Obstet, 2015, 291: 287-98. PMID:25367598.

225 Mullaney, Laura, Brennan, Aisling, Cawley, Shona et al. Relationship between fasting plasma Independent variable glucose levels and maternal food group and macronutrient intakes in pregnancy. Dietetics, 2016, 73: 441-447

226 Munson, M., Saatkamp, R., West, C. Late preterm infants: steps to success. Neonatal Netw, 2011, 30: 267-70. PMID:21729860.

227 Musaiger, A. O. Food habits of mothers and children in two regions of Oman. Nutr Health, 1996, 11: 29-48. PMID:8817582.

228 Musselman, J. R., Jurek, A. M., Johnson, K. J. et al. Maternal dietary patterns during early pregnancy and the odds of childhood germ cell tumors: A Children's Oncology Group study. Am J Epidemiol, 2011, 173: 282-91. PMID:21098631.

229 Myhre, R., Brantsaeter, A. L., Myking, S. et al. Intakes of garlic and dried fruits are associated Independent variable with lower risk of spontaneous preterm delivery. J Nutr, 2013, 143: 1100-8. PMID:23700347.

230 Newman, Ak, Deussen, Ar, Moran, Lj et al. The effect of antenatal dietary and lifestyle advice on maternal psychological health in women who are overweight or obese-findings from the limit randomised trial. Journal of Paediatrics and Child Health [abstracts of the 17th Congress of the Perinatal Society of Australia and New Zealand, , 2013, 49

Independent variable, study design

\section{Dependent variable}

Independent variable

Duplicate

Dependent variable

Independent variable

Dependent variable

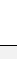




\section{Citation}

\section{Rationale}

231 Ney, D., Hollingsworth, D. R., Cousins, L. Decreased insulin requirement and improved control of diabetes in pregnant women given a high-carbohydrate, high-fiber, low-fat diet. Diabetes Care, 1982, 5: 529-33. PMID:6329613.

232 Nicholls, M. G. Reduction of dietary sodium in Western Society. Benefit or risk?. Hypertension, Study design 1984, 6: 795-801. PMID:6394485.

233 Niedhammer, I., Murrin, C., O'Mahony, D. et al. Explanations for social inequalities in preterm Independent variable delivery in the prospective Lifeways cohort in the Republic of Ireland. Eur J Public Health, 2012, 22: 533-8. PMID:21746747.

234 Odent, M. Land food .. sea food .. brain food. Midwifery Today Childbirth Educ, 1996, : 18-20. Study design PMID:9016057.

235 Olafsdottir, A. S., Skuladottir, G. V., Thorsdottir, I. et al. Maternal diet in early and late pregnancy in relation to weight gain. Int J Obes (Lond), 2006, 30: 492-9. PMID:16331301.

236 Olsen, S. F., Beck, D. N., Kollslid, R. et al. High birth weights in prewar Faroe Islands. J Epidemiol Community Health, 2001, 55. PMID:11160178.

237 Olsen, S. F., Grandjean, P., Weihe, P. et al. Frequency of seafood intake in pregnancy as a determinant of birth weight: evidence for a dose dependent relationship. J Epidemiol Community Health, 1993, 47: 436-40. PMID:8120495.

238 Olsen, S. F., Secher, N. J. Low consumption of seafood in early pregnancy as a risk factor for Independent variable preterm delivery: prospective cohort study. Bmj, 2002, 324. PMID:11859044.

239 Paisey, R. B., Hartog, M., Savage, P. A high-fibre diet in gestational diabetes--wheat fibre, leguminous fibre or both?. Hum Nutr Appl Nutr, 1987, 41: 146-9. PMID:3032872.

240 Papadopoulou, E., Kogevinas, M., Botsivali, M. et al. Maternal diet, prenatal exposure to dioxin-like compounds and birth outcomes in a European prospective mother-child study (NewGeneris). Sci Total Environ, 2014, 484: 121-8. PMID:24691212.

241 Papazian, T., Hout, H., Sibai, D. et al. Development, reproducibility and validity of a food frequency questionnaire among pregnant women adherent to the Mediterranean dietary pattern. Clinical Nutrition, 2016, 35: 1550-1556

242 Pedersen, M., von Stedingk, H., Botsivali, M. et al. Birth weight, head circumference, and prenatal exposure to acrylamide from maternal diet: the European prospective mother-child study (NewGeneris). Environ Health Perspect, 2012, 120: 1739-45. PMID:23092936. 


\section{Citation}

\section{Rationale}

243 Pentieva, K., Petrova, S., Ovcharova, D. et al. Influence of some sociodemographic factors and smoking on the risk for intrauterine growth retardation. Khigiena i Zdraveopazvane, 1996, 39: 5-8

244 Perez-Ferre, N., Fernandez, D., Torrejon, M. J. et al. Effect of lifestyle on the risk of gestational diabetes and obstetric outcomes in immigrant Hispanic women living in Spain. J Diabetes, 2012, 4: 432-8. PMID:22742428.

245 Persson, B, Stangenberg, M, Hansson, U et al. Gestational diabetes mellitus (GDM): comparative evaluation of two treatment regimens, diet vs insulin and diet. Diabetes, 1985, 34: $101-5$

246 Petrella, E., Malavolti, M., Bertarini, V. et al. Gestational weight gain in overweight and obese women enrolled in a healthy lifestyle and eating habits program. J Matern Fetal Neonatal Med, 2014, 27: 1348-52. PMID:24175912.

247 Petridou, E., Stoikidou, M., Diamantopoulou, M. et al. Diet during pregnancy in relation to birthweight in healthy singletons. Child Care Health Dev, 1998, 24: 229-42. PMID:9618037.

248 Phelan, S., Hart, C., Phipps, M. et al. Maternal behaviors during pregnancy impact offspring Independent variable obesity risk. Exp Diabetes Res, 2011, 2011. PMID:22110475.

249 Picaud, Jc, Lapillonne, A, Boucher, P et al. Dietary cholesterol does not affect vitamin D metabolism in preterm infants : preliminary results. Pediatr Res, 1999, 45

250 Picone, T. A., Allen, L. H., Olsen, P. N. et al. Pregnancy outcome in North American women. II. Effects of diet, cigarette smoking, stress, and weight gain on placentas, and on neonatal physical and behavioral characteristics. Am J Clin Nutr, 1982, 36: 1214-24. PMID:7148740.

251 Pinto, E., Barros, H., dos Santos Silva, I. Dietary intake and nutritional adequacy prior to conception and during pregnancy: a follow-up study in the north of Portugal. Public Health Nutr, 2009, 12: 922-31. PMID:18752697.

252 Piraquive, J, Grieve, P, Sudha, K et al. Quality of Diet and Central Nervous System Activity in Independent variable Low Birth Weight Infants. Pediatric Academic Societies Annual Meeting, 2013,

253 Popeski, D., Ebbeling, L. R., Brown, P. B. et al. Blood pressure during pregnancy in Canadian Independent variable Inuit: community differences related to diet. Cmaj, 1991, 145: 445-54. PMID:1878826.

254 Qiu, C., Coughlin, K. B., Frederick, I. O. et al. Dietary fiber intake in early pregnancy and risk Independent variable of subsequent preeclampsia. Am J Hypertens, 2008, 21: 903-9. PMID:18636070. 


\section{Citation}

\section{Rationale}

255 Qiu, C., Zhang, C., Gelaye, B. et al. Gestational diabetes mellitus in relation to maternal dietary heme iron and nonheme iron intake. Diabetes Care, 2011, 34: 1564-9. PMID:21709295.

256 Radder, J. K., Terpstra, J. Comparison of postprandial (lunch tolerance) and postglucose (oral 10: 163-71. PMID:7189481.

257 Raman, L. Influence of maternal nutritional factors affecting birthweight. Am J Clin Nutr, 1981, Country 34: 775-83. PMID:7223693.

258 Ramon, R., Ballester, F., Aguinagalde, X. et al. Fish consumption during pregnancy, prenatal mercury exposure, and anthropometric measures at birth in a prospective mother-infant cohort study in Spain. Am J Clin Nutr, 2009, 90: 1047-55. PMID:19710189.

259 Ramon, R., Ballester, F., Iniguez, C. et al. Vegetable but not fruit intake during pregnancy is associated with newborn anthropometric measures. J Nutr, 2009, 139: 561-7.

PMID:19158218.

260 Ramos-LevÃ, A. M., PÃ@rez-Ferre, N., FernÃ jndez, M. D. et al. Risk factors for gestational diabetes mellitus in a large population of women living in Spain: Implications for preventative strategies. International Journal of Endocrinology, 2012, 2012

\section{Independent variable}

Ray, J. G., Mamdani, M. M. Association between folic acid food fortification and hypertension or preeclampsia in pregnancy. Arch Intern Med, 2002, 162: 1776-7. PMID:12153382.

262 Reddy, S., Sanders, T. A., Obeid, O. The influence of maternal vegetarian diet on essential fatty acid status of the newborn. Eur J Clin Nutr, 1994, 48: 358-68. PMID:8055852.

263 Reece, Ea, Gay, L, DeGennaro, N et al. A randomized clinical trial of a fiber-enriched diabetic diet vs the standard American Diabetes Association recommended diet in the management of diabetes mellitus in pregnancy. Proceedings of 10th Annual Meeting of Society of Perinatal Obstetricians; 1990 Jan 23-27; Houston, Texas, USA, 1990,

264 Renzaho, A. M., Skouteris, H., Oldroyd, J. Preventing gestational diabetes mellitus among migrant women and reducing obesity and type 2 diabetes in their offspring: a call for culturally competent lifestyle interventions in pregnancy. J Am Diet Assoc, 2010, 110: 1814-7. PMID:21111090.

265 Rhodes, E. T., Pawlak, D. B., Takoudes, T. C. et al. Effects of a low-glycemic load diet in overweight and obese pregnant women: a pilot randomized controlled trial. Am J Clin Nutr, 2010, 92: 1306-15. PMID:20962162.

Independent variable, study design

Independent variable

Independent variable

Not peer-reviewed

Study design

Independent variable 


\section{Citation}

\section{Rationale}

266 Ribeiro, M. D. Diet and pregnancy toxemia: new thoughts on an old problem. Public Health Rev, 1982, 10: 149-67. PMID:7167640.

267 Rogers, I., Emmett, P., Baker, D. et al. Financial difficulties, smoking habits, composition of the diet and birthweight in a population of pregnant women in the South West of England. ALSPAC Study Team. Avon Longitudinal Study of Pregnancy and Childhood. Eur J Clin Nutr, 1998, 52: 251-60. PMID:9578337.

268 Ross, Ra, Perlzweig, Wa, Taylor, Hm et al. A study of certain dietary factors of possible etiologic significance in toxemias of pregnancy. Am J Obstet Gynecol, 1938, 35: 426-40

269 Ruiz-Gracia, T., Duran, A., Fuentes, M. et al. Lifestyle patterns in early pregnancy linked to gestational diabetes mellitus diagnoses when using IADPSG criteria. The St Carlos gestational study. Clin Nutr, 2016, 35: 699-705. PMID:25998584.

270 Rush, D., Stein, Z., Susser, M. Diet in pregnancy: a randomized controlled trial of nutritional supplements. Birth Defects Orig Artic Ser, 1980, 16. PMID:7000197.

271 Saldana, T. M., Siega-Riz, A. M., Adair, L. S. Effect of macronutrient intake on the development of glucose intolerance during pregnancy. Am J Clin Nutr, 2004, 79: 479-86. PMID:14985225.

272 Sanders, T. A., Reddy, S. The influence of a vegetarian diet on the fatty acid composition of human milk and the essential fatty acid status of the infant. J Pediatr, 1992, 120. PMID:1560329.

273 Sauder, K. A., Starling, A. P., Shapiro, A. L. et al. Diet, physical activity and mental health status are associated with dysglycaemia in pregnancy: the Healthy Start Study. Diabet Med, 2016, 33: 663-7. PMID:26872289.

274 Saunders, J. B. Investing in healthy babies. NCSL Legisbrief, 2009, 17: 1-2. PMID:19301480.

Not peer-reviewed

275 Saunders, L., Guldner, L., Costet, N. et al. Effect of a Mediterranean diet during pregnancy on fetal growth and preterm delivery: results from a French Caribbean Mother-Child Cohort Study (TIMOUN). Paediatr Perinat Epidemiol, 2014, 28: 235-44. PMID:24754337.

276 Savard, N., Levallois, P., Rivest, L. P. et al. Impact of individual and ecological characteristics on small for gestational age births: an observational study in Quebec. Chronic Dis Inj Can, 2014, 34: 46-54. PMID:24618381.

277 Schneck, M. E., Sideras, K. S., Fox, R. A. et al. Low-income pregnant adolescents and their infants: dietary findings and health outcomes. J Am Diet Assoc, 1990, 90: 555-8. PMID:2319076. 


\section{Citation}

Rationale

278 Scott, F. W., Kolb, H. Dietary intervention for diabetes prevention in the neonate. Diabetes Metab Rev, 1998, 14. PMID:9605633.

279 Seely, E. W., Maxwell, C. Cardiology patient page. Chronic hypertension in pregnancy. Circulation, 2007, 115. PMID:17309919.

Study design

Independent variable, study design

280 Sen, S., Rifas-Shiman, S. L., Shivappa, N. et al. Dietary Inflammatory Potential during Pregnancy Is Associated with Lower Fetal Growth and Breastfeeding Failure: Results from Project Viva. J Nutr, 2016, 146: 728-36. PMID:26936137.

281 Shin, D., Lee, K. W., Song, W. O. Dietary Patterns during Pregnancy Are Associated with Risk Study design of Gestational Diabetes Mellitus. Nutrients, 2015, 7: 9369-82. PMID:26569302.

282 Siega-Riz, A. M., Herrmann, T. S., Savitz, D. A. et al. Frequency of eating during pregnancy Independent variable and its effect on preterm delivery. Am J Epidemiol, 2001, 153: 647-52. PMID:11282791.

283 Siega-Riz, A. M., Savitz, D. A., Zeisel, S. H. et al. Second trimester folate status and preterm Independent variable birth. Am J Obstet Gynecol, 2004, 191: 1851-7. PMID:15592264.

284 Simoes-Wust, A. P., Kummeling, I., Mommers, M. et al. Influence of alternative lifestyles on Independent variable self-reported body weight and health characteristics in women. Eur J Public Health, 2014, 24 : 321-7. PMID:23639916.

285 Sister, MorningStar. Sick pregnancies. Midwifery Today Int Midwife, 2014, : 12-5. PMID:25980101.

286 Smeeth, L., Williams, D. Can a dietary supplement prevent pre-eclampsia? L-arginine with vitamins show promise, but there are good grounds for caution. Bmj, 2011, 342

287 Smith, L. K., Draper, E. S., Evans, T. A. et al. Associations between late and moderately preterm birth and smoking, alcohol, drug use and diet: a population-based case-cohort study. Arch Dis Child Fetal Neonatal Ed, 2015, 100. PMID:25972442.

288 Smith, V. M. Preterm infant nutrition. Midwives Chron, 1989, 102: 143-6. PMID:2725350.

289 Sokup, A., Mioduszewska, M., Bal§k, A. et al. Unhealthy eating habits precede gestational diabetes mellitus in Polish women Part I: Evaluation of frequency, regularity of consumed meals and consumed snacks, bread, sweets, fruit and vegetables. Eating habits and gestational diabetes. Diabetologia Doswiadczalna i Kliniczna, 2010, 10: 17-22
Independent variable

Study design, non peer-reviewed

Independent variable

Study design

Study design

Independent variable, health status 


\section{Citation}

Rationale

290 Soto, R., Guilloty, N., Anzalota, L. et al. Association between maternal diet factors and hemoglobin levels, glucose tolerance, blood pressure and gestational age in a Hispanic population. Arch Latinoam Nutr, 2015, 65: 86-96. PMID:26817380.

291 Souza, Lalitha, Jayaweera, Hiranthi, Pickett, Kate E. Pregnancy diets, migration, and birth outcomes. Health Care Women Int, 2016, 37: 964-978

292 Sparks, J. W. Fetal growth and diet. Mead Johnson Symp Perinat Dev Med, 1984, : 21-7. PMID:6545381.

293 Standards of care of diabetes mellitus in pregnancy. Diabetologie Metabolismus Endokrinologie Vyziva, 2007, 10: 229-231

294 Steegers, E. A., Van Lakwijk, H. P., Jongsma, H. W. et al. (Patho)physiological implications of chronic dietary sodium restriction during pregnancy; a longitudinal prospective randomized study. Br J Obstet Gynaecol, 1991, 98: 980-7. PMID:1751444.

295 Steegers, E. A. P., Van Lakwijk, H. P. J. M., Jongsma, H. W. et al. (Patho)physiological implications of chronic dietary sodium restriction during pregnancy; a longitudinal prospective randomzied study. Br J Obstet Gynaecol, 1991, 98: 980-987

296 Steegers, Eap, Buul, Eja. Chronic dietary sodium restriction in the prevention of hypertension during pregnancy: preliminary results of a Dutch multicentered trial. 9th International Congress of the International Society for the Study of Hypertension in Pregnancy; 1994 March 15-18; Sydney, A, 1994,

297 Stein, A. Adressing disturbances in the relationship between mothers with eating disorders and their infants: a randomized controlled trial. Personal communication, 2004,

Stein, A. The influence of maternal eating disorder on infant development: an intervention study. ControlledTrials.com [http://www.controlled-trials.com/ISRCTN95026274], 2004,

\section{Study design}

Study design

Study design, language

Independent variable Duplicate

\section{Not peer-reviewed}

Independent variable, not peer reviewed

Independent variable, not peer reviewed

299 Stephens, T. V., Woo, H., Innis, S. M. et al. Healthy pregnant women in Canada are consuming more dietary protein at 16- and 36-week gestation than currently recommended by the Dietary Reference Intakes, primarily from dairy food sources. Nutr Res, 2014, 34: 569-76. PMID:25150115. 


\section{Citation}

Rationale

300 Stuckey-Schrock, K., Schrock, S. D. Head off complications in late preterm infants. J Fam Pract, 2013, 62. PMID:23570036.

Independent variable, study

design

301 Suhail, M., Suhail, M. F., Khan, H. Role of vitamins C and E in regulating antioxidant and prooxidant markers in preeclampsia. Journal of Clinical Biochemistry and Nutrition, 2008, 43: 210220

302 Svenningsen, Nw, Lindquist, B. Incidence of metabolic acidosis in term, preterm and small for gestational age infants in relation to dietary protein intake. Acta Paediatr Scand, 1973, 62: 110

303 Switkowski, K. M., Jacques, P. F., Must, A. et al. Maternal protein intake during pregnancy and linear growth in the offspring. Am J Clin Nutr, 2016, 104: 1128-1136. PMID:27581477.

Country Symonds, M. E., Budge, H., Edwards, L. J. et al. Maternal nutrition, cortisol and programming No full text

304 Symotal development. Perinatology, 2002, 4: 67-74

305 Tande, D. L., Ralph, J. L., Johnson, L. K. et al. First trimester dietary intake, biochemical measures, and subsequent gestational hypertension among nulliparous women. J Midwifery Womens Health, 2013, 58: 423-30. PMID:23895215.

306 Tanha, F. D., Mohseni, M., Ghajarzadeh, M. et al. The effects of healthy diet in pregnancy. Journal of Family and Reproductive Health, 2013, 7: 121-125

\section{Date}

307 Taylor, C. M., Golding, J., Emond, A. M. Blood mercury levels and fish consumption in pregnancy: Risks and benefits for birth outcomes in a prospective observational birth cohort. Int J Hyg Environ Health, 2016, 219: 513-20. PMID:27252152.

308 Thacker, S. M., Petkewicz, K. A. Gestational diabetes mellitus. U.S. Pharm., 2009, 34: 43-48

309 Thomas, B., Ghebremeskel, K., Lowy, C. et al. Nutrient intake of women with and without gestational diabetes with a specific focus on fatty acids. Nutrition, 2006, 22: 230-6. PMID:16500549.

\author{
Independent \\ variable, dependent \\ variable
} Independent variable Study design Independent variable, study design

310 Thomas, D. M., Clapp, J. F., Shernce, S. A foetal energy balance equation based on maternal Independent variable exercise and diet. J R Soc Interface, 2008, 5: 449-55. PMID:17895222. 


\section{Citation}

\section{Rationale}

311 Thompson, J. M., Wall, C., Becroft, D. M. et al. Maternal dietary patterns in pregnancy and the Study design association with small-for-gestational-age infants. Br J Nutr, 2010, 103: 1665-73.

PMID:20211035.

312 Tielemans, M. J., Erler, N. S., Leermakers, E. T. M. et al. A Priori and a Posteriori dietary patterns during pregnancy and gestational weight gain: The generation R study. Nutrients, 2015, 7: 9383-9399

313 Tobias, D. K., Zhang, C., Chavarro, J. et al. Healthful dietary patterns and long-term weight change among women with a history of gestational diabetes mellitus. Int J Obes (Lond), 2016, 40: 1748-1753. PMID:27569683.

314 Tovar, A., Must, A., Bermudez, O. I. et al. The impact of gestational weight gain and diet on abnormal glucose tolerance during pregnancy in Hispanic women. Matern Child Health $\mathrm{J}$, 2009, 13: 520-30. PMID:18597166.

315 Uusitalo, U., Arkkola, T., Ovaskainen, M. L. et al. Unhealthy dietary patterns are associated with weight gain during pregnancy among Finnish women. Public Health Nutr, 2009, 12: 23929. PMID:19323867.

316 Valentini, R., Dalfra, M. G., Masin, M. et al. A pilot study on dietary approaches in multiethnicity: two methods compared. Int J Endocrinol, 2012, 2012. PMID:22505892.

317 Van Buul, B. J. A., Steegers, E. A. P., Van Der Maten, G. D. et al. Dietary sodium restriction does not prevent gestational hypertension: A Dutch two-center randomized trial. Hypertension in Pregnancy, 1997, 16: 335-346

318 van Buul, B. J., Steegers, E. A., Jongsma, H. W. et al. Dietary sodium restriction in the prophylaxis of hypertensive disorders of pregnancy: effects on the intake of other nutrients.

Dependent variable Am J Clin Nutr, 1995, 62: 49-57. PMID:7598066.

319 van der Maten, G. D. Low sodium diet in pregnancy: effects on maternal nutritional status. Eur Independent variable J Obstet Gynecol Reprod Biol, 1995, 61: 63-4. PMID:8549849.

320 van der Maten, G. D., van Raaij, J. M., Visman, L. et al. Low-sodium diet in pregnancy: effects Independent variable on blood pressure and maternal nutritional status. Br J Nutr, 1997, 77: 703-20. PMID:9175991.

321 Vejrup, K., Brantsaeter, A. L., Knutsen, H. K. et al. Prenatal mercury exposure and infant birth weight in the Norwegian Mother and Child Cohort Study. Public Health Nutr, 2014, 17: 2071 80. PMID:24103413. 


\section{Citation}

\section{Rationale}

322 Vilela, A. A., Pinto Tde, J., Rebelo, F. et al. Association of Prepregnancy Dietary Patterns and

Dependent variable

Anxiety Symptoms from Midpregnancy to Early Postpartum in a Prospective Cohort of

Brazilian Women. J Acad Nutr Diet, 2015, 115: 1626-35. PMID:25769749.

323 gain weight speed of pregnant women attended in a primary care service. Revista Brasileira de Ginecologia e Obstetricia, 2011, 33: 13-19

324 Wakimoto, Patricia, Akabike, Andrea, King, Janet C. Maternal Nutrition and Pregnancy Outcomeâ€"A Look Back. Nutrition Today, 2015, 50: 221-229

Language

Walsh, J. M., Mahony, R. M., Culliton, M. et al. Impact of a low glycemic index diet in pregnancy on markers of maternal and fetal metabolism and inflammation. Reprod Sci, 2014, 21: 1378-81. PMID:24642719.

326 Walsh, J. M., McGowan, C. A., Mahony, R. et al. Low glycaemic index diet in pregnancy to prevent macrosomia (ROLO study): randomised control trial. Bmj, 2012, 345. PMID:22936795.

327 Wang, C., Zhu, W., Wei, Y. et al. Exercise intervention during pregnancy can be used to manage weight gain and improve pregnancy outcomes in women with gestational diabetes mellitus. BMC Pregnancy Childbirth, 2015, 15. PMID:26459271. predictor of high birthweight: findings from the healthy beginnings trial. Birth, 2013, 40: 46-51. PMID:24635424.

330 Wheeler, S. J., Poston, L., Thomas, J. E. et al. Maternal plasma fatty acid composition and pregnancy outcome in adolescents. Br J Nutr, 2011, 105: 601-10. PMID:21269546.

331 Widga, A. C., Lewis, N. M. Defined, in-home, prenatal nutrition intervention for low-income women. J Am Diet Assoc, 1999, 99. PMID:10491673.

332 Williams, C., Highley, W., Ma, E. H. et al. Protein, amino acid, and caloric intakes of selected Independent variable pregnant women. J Am Diet Assoc, 1981, 78: 28-35. PMID:7217557.

333 Williams, E. J. Gestational diabetes mellitus and diet control. Diabetes Educ, 1986, 12: 16-7. Study design PMID:3633805.

334 Wolff, C. B., Wolff, H. K. Maternal eating patterns and birth weight of Mexican American infants. Nutr Health, 1995, 10: 121-34. PMID:7491165. 


\section{Citation}

\section{Rationale} 336 Wynn, A. H., Crawford, M. A., Doyle, W. et al. Nutrition of women in anticipation of pregnancy. Independent variable
Nutr Health, 1991, 7: 69-88. PMID:2038457.

337 Zielinsky, P., Piccoli,, Vian, I. et al. Maternal restriction of polyphenols and fetal ductal dynamics in normal pregnancy: an open clinical trial. Arq Bras Cardiol, 2013, 101: 217-25. PMID:23949325. 